\title{
ECONOMICS
}

\section{DISPARITIES IN INCOMES AND PRICES INTERNATIONALLY}

\author{
by
}

Kenneth W Clements

Grace Gao

and

Thomas Simpson

Business School

University of Western Australia

DISCUSSION PAPER 12.01 
November 2011

\title{
DISPARITIES IN INCOMES AND PRICES INTERNATIONALLY
}

\author{
by \\ Kenneth W Clements, Grace Gao \\ and Thomas Simpson* \\ Business School \\ University of Western Australia
}

DISCUSSION PAPER 12.01

\begin{abstract}
$\underline{\text { Abstract }}$
The dispersion of the distribution of relative prices in poor countries is substantially higher than that in the rich. As in $130+$ countries relative prices are closely related to incomes, we develop a model that shows that the prices of luxuries (necessities) rise (fall) with income growth. This model provides a link between price dispersion and incomes that leads to several interesting concepts, including minimum-variance income and dispersion-equivalent income, the income needed to compensate for higher dispersion, which are illustrated with data from the International Comparison Program. The paper also contains an analysis of the welfare cost of higher dispersion in poorer countries.
\end{abstract}

\footnotetext{
* Kenneth Clements is a Winthrop Professor of Economics and BHP Billiton Research Fellow, Grace Gao is a PhD student and Thomas Simpson is a Research Assistant, all at the Business School, UWA. We thank Mei-Hsiu Chen for research assistance. This research was supported in part by BHP Billiton and the ARC.
} 


\section{Introduction}

This paper investigates how and why economies differ. This is, of course, a large, multidimensional issue as economies differ with respect to incomes, factor endowments, overall scale, institutions and policy, as well as noneconomic attributes such as geography, climate and, possibly, the historical and cultural context. Many of these factors are linked in one way or another, but they need to be compressed to keep things manageable. We focus on differences across countries in incomes and the structure of relative prices and their interactions. While it is an exaggeration to describe incomes and prices as "sufficient statistics" for the economy, they do summarise much information in a compact, convenient and economically relevant way.

Perhaps the most famous approach to understanding cross-country differences in incomes and prices is the Balassa (1964)-Samuelson (1964) productivity bias model. Here, relative to poor countries, high-income countries are taken to be more productive in all commodities, but relatively more so in the tradeables sector, less so in nontradeables. The reason for the asymmetry is that tradeables (such as agricultural goods and minerals) are supposed to be more amenable to productivity improvement than nontradeables (services such as education and medical care). The higher marginal productivity of labour in the traded goods sector means higher wages are paid there and if labour is sufficiently mobile across sectors, wages are higher in the nontraded sector also. The higher costs in nontradables are passed on in terms of higher prices, while traded goods prices are fixed at world values. The result is that tradeables are relatively cheaper in rich countries, or nontradeables are more expensive. For more recent discussions of systematic patterns in prices across countries, see Bhagwati (1984), Bergin et al. (2006), Hsieh and Klenow (2007), Simonovska (2010) and Summers and Heston (1991).

In addition to the productivity bias hypothesis, there are two other streams of literature on the structure of relative prices internationally. First, Theil (1967, Chpt 5) uses Divisia-type concepts to measure how prices and quantities differ across six European countries/regions. This involves the comparison of the price of commodity $i$ in country a with that in $b, p_{i a} / p_{i b}$, that leads to a bilateral index of the price level in a relative to b. For this purpose, Theil uses the weighted geometric mean, the logarithm of which is $\sum_{\mathrm{i}=1}^{\mathrm{n}} \mathrm{W}_{\mathrm{i}, \mathrm{ab}} \log \left(\mathrm{p}_{\mathrm{ia}} / \mathrm{p}_{\mathrm{ib}}\right)$, where $\mathrm{n}$ is the number of commodities and $\mathrm{w}_{\mathrm{i}, \mathrm{ab}}$ is the weight that reflects the relative importance of commodity $i$ in the two countries. Also considered is the analogous bilateral variance which measures the dispersion of the individual prices around the average. If prices in one country are proportional to those in another, the variance is zero and the structure of relative prices is the same in the two countries. For further developments along these lines, see Theil (1996, Chpt. 5). 
The second stream of this literature is due to Kravis et al. (1982, pp. 104-109), who group countries on the basis of several criteria, one of which is the similarity of the structure of prices. They introduce a bilateral "similarity index", defined as the weighted correlation coefficient between prices in two countries. Another similarity measure these authors use is the Paasche-Laspeyres spread, defined as the ratio of the Paasche to the Laspeyres price index (Kravis et al., 1982, pp. 105, 109-110). It can be shown that this spread increases with variance of relative prices and so is related to the correlation coefficient. Diewert (2009) presents an axiomatic approach to similarity indexes of prices across countries; see also Cuthbert (2009) and Sergeev (2009). ${ }^{1}$

This paper advances both the theory and measurement of cross-country differences in incomes and prices. In Section 2, we first measure the dispersion of prices within a country by the cross-commodity weighted variance and then show in Section 3 how this concept is linked to the law of one price. Section 4 applies this dispersion measure to data from the International Comparison Program (2008) for 130+ countries, which leads to the "world" price distribution. An attractive feature of our approach is that the variance of the world distribution is simply the average of that in each country, with the "between country" effect vanishing. Next, in Section 5, we propose a simple pricing model that shows that under not unreasonable conditions the relative prices of luxuries (necessities) rise (fall) with income growth. We identify a systematic difference in pricing behaviour for rich and poor countries. This model provides a link between price dispersion and income that leads to several interesting concepts including the minimum-variance value of income and dispersion-equivalent income, the additional income that compensates for higher dispersion in the poor countries; these issues are explored in Sections 6 and 7. Section 8 analyses the welfare economics of price dispersion and Section 9 contains concluding comments.

\section{The Distribution of Prices}

This section introduces measures that summarise the distribution of prices in the form of its centre of gravity and dispersion.

For $\operatorname{good} \mathrm{i}(\mathrm{i}=1, \ldots, \mathrm{n})$ in country $\mathrm{c}(\mathrm{c}=1, \ldots, \mathrm{C})$, let $\mathrm{p}_{\mathrm{ic}}, \mathrm{q}_{\mathrm{ic}}$ and $\mathrm{w}_{\mathrm{ic}}=\mathrm{p}_{\mathrm{ic}} \mathrm{q}_{\mathrm{ic}} / \mathrm{M}_{\mathrm{c}}$ be the price, quantity consumed and budget share, where $\mathrm{M}_{\mathrm{c}}=\sum_{\mathrm{i}=1}^{\mathrm{n}} \mathrm{p}_{\mathrm{ic}} \mathrm{q}_{\mathrm{ic}}$ is total expenditure. Consider the probability distribution of the prices of the $n$ commodities in country $c, p_{1 c}, \ldots, p_{n c}$. A simple way of summarising this distribution is by the first two moments. It is appropriate to use a weighting scheme that recognises that some goods are more important than others in terms of spending. We use the weighted geometric mean, using the budget shares as weights to represent the relative importance of each good. The logarithm of this mean is:

\footnotetext{
${ }^{1}$ For a recent study of patterns of relative prices across countries that emphasises the traded/nontraded goods distinction, see Thomas et al. (2011).
} 


$$
\log \mathrm{P}_{\mathrm{c}}=\sum_{\mathrm{i}=1}^{\mathrm{n}} \mathrm{w}_{\mathrm{ic}} \log \mathrm{p}_{\mathrm{ic}} \cdot
$$

As $\log \mathrm{P}_{\mathrm{c}}$ weights prices in proportion to expenditures, it is a cost-of-living index. This index has an attractively simple sampling interpretation (Theil, 1967, pp. 136-137). For convenience, write $\log \mathrm{p}_{\text {ic }}$ as $\mathrm{X}_{\mathrm{ic}}$, and consider a discrete random variable $\mathrm{X}_{\mathrm{c}}$ that can take the $\mathrm{n}$ possible values $\mathrm{x}_{\mathrm{lc}}, \ldots, \mathrm{X}_{\mathrm{nc}}$. Regarding the probabilities attached to these $n$ realisations, suppose the names of goods are drawn at random from this distribution such that each dollar of spending has an equal chance of being selected. This means that the probability of drawing $\mathrm{x}_{\mathrm{ic}}$ is its budget share $\mathrm{w}_{\mathrm{ic}}$. Accordingly, the expected value of the random variable $\mathrm{X}_{\mathrm{c}}$ is $\mathrm{E}\left(\mathrm{X}_{\mathrm{c}}\right)=\sum_{\mathrm{i}=1}^{\mathrm{n}} \mathrm{w}_{\mathrm{ic}} \mathrm{X}_{\mathrm{ic}}$, which coincides with index (1). Thus, the index $\log \mathrm{P}_{\mathrm{c}}$ can be interpreted as the expected value of the (logarithmic) prices, so it is an appealing way of summarising the cost of the budget.

The above index is a weighted first-order moment of the cross-commodity distribution of prices. The corresponding second-order moment is

(2) $\Pi_{\mathrm{c}}=\sum_{\mathrm{i}=1}^{\mathrm{n}} \mathrm{w}_{\mathrm{ic}}\left(\log \mathrm{p}_{\mathrm{ic}}-\log \mathrm{P}_{\mathrm{c}}\right)^{2}$,

which, for country $\mathrm{c}$, is a measure of dispersion of the distribution of prices. If each of the $\mathrm{n}$ prices coincide with the mean, then $\Pi_{c}=0$.

\section{Prices at Home and Abroad}

This section considers aspects of the way in which prices are measured and their implications. We start with price comparisons within a country and then turn to bilateral relationships.

Expensive and Cheap Goods

In what sense is it possible to identify those goods that are expensive and those that are cheap? As the price $\mathrm{p}_{\text {ic }}$ is measured in terms of domestic currency units of country c per unit of good $\mathrm{i}$, the use of this price in cross-country comparisons is unsatisfactory. The relative price $\log \mathrm{p}_{\mathrm{ic}}-\log \mathrm{P}_{\mathrm{c}}$ is a pure number, independent of currency units, but not independent of the units of measurement of good $i$. To see this, consider, for example, the case of $i=$ food and suppose we initially measure its volume $\left(\mathrm{q}_{i}^{\text {old }}\right)$ in terms of kilograms per year. This means that the corresponding price $\left(\mathrm{p}_{\mathrm{i}}^{\text {old }}\right)$ is in terms of local dollars per kilo in order to satisfy the accounting identity $p_{i}^{\text {old }} \times q_{i}^{\text {old }}=X$, where $X$ is given food expenditure (dollars per year). If we now switch to grams, then as $1,000 \mathrm{~g}=1 \mathrm{k}, \mathrm{p}_{\mathrm{i}}^{\text {new }}=\mathrm{p}_{\mathrm{i}}^{\text {old }} / 1,000$ and $\mathrm{q}_{\mathrm{i}}^{\text {new }}=\mathrm{q}_{\mathrm{i}}^{\text {old }} \times 1,000$, which satisfy $\mathrm{p}_{\mathrm{i}}^{\text {new }} \times \mathrm{q}_{\mathrm{i}}^{\text {new }}=\mathrm{X}$. Furthermore, 
the index of prices under the new measurement regime satisfies $\log \mathrm{P}^{\text {new }}=\log \mathrm{P}^{\text {old }}-\mathrm{w}_{\mathrm{i}} \log (1,000)$, so that the difference between the corresponding relative prices is

$$
\left(\log \mathrm{p}_{\mathrm{i}}^{\text {new }}-\log \mathrm{P}^{\text {new }}\right)-\left(\log \mathrm{p}_{\mathrm{i}}^{\text {old }}-\log \mathrm{P}^{\text {old }}\right)=-\left(1-\mathrm{w}_{\mathrm{i}}\right) \log (1,000) .
$$

For $0<\mathrm{w}_{\mathrm{i}}<1$, this difference is nonzero, which establishes a lack of invariance of relative prices to the choice of the units of measurement of the quantities.

The above problem can be resolved by fixing on the quantity units. One approach would be to measure the quantity consumed of good i as its value in US dollars, so that the corresponding price is the domestic-currency cost of one US dollar's worth of the good. In fact, as the currency unit is not present in the relative price $\log \mathrm{p}_{\mathrm{i}}-\log \mathrm{P}$, this is not dependent on the US dollar as the base, so we could equally well use the euro for this purpose. Subsequently, we use the International Comparison Project (2008) data, where consumption of each of the $n$ goods is expressed in terms of US dollars. An implication of measuring quantities in terms of US dollars is that the $n$ prices $\left(\mathrm{p}_{1 \mathrm{c}}, \ldots, \mathrm{p}_{\mathrm{nc}}\right)$ are directly comparable across commodities. That is, as $\mathrm{p}_{\text {ic }}$ is the domestic-currency price of a US dollar's worth of good $i$, if $p_{i c}>p_{j c}$, then good $i$ is more expensive than $j$ in country c. For comparisons of prices in different countries, currency units have to be removed and we can use the relative price $\log \mathrm{p}_{\mathrm{ic}}-\log \mathrm{P}_{\mathrm{c}}$. Good $\mathrm{i}$ is then relatively more expensive in country $\mathrm{c}$ than in $\mathrm{d}$ when $\log \mathrm{p}_{\mathrm{ic}}-\log \mathrm{P}_{\mathrm{c}}>\log \mathrm{p}_{\mathrm{id}}-\log \mathrm{P}_{\mathrm{d}}$.

\section{The Law of One Price}

In the context of prices in different countries, it is relevant to mention the law of one price (LOP). Here, arbitrage equalises prices across countries, when prices are expressed in terms of a common currency. ${ }^{2}$ To examine the implications of the LOP, let $\mathrm{S}_{\mathrm{c}}$ be the market exchange rate for c, defined as the domestic currency cost of one US dollar, so that an increase in $\mathrm{S}_{\mathrm{c}}$ represents a depreciation of the currency of $\mathrm{c}$, and let $\mathrm{p}_{\mathrm{i}}^{*}$ be the cost of good $\mathrm{i}$ in the US in US dollars (the "world price"). ${ }^{3}$ If $\mathrm{k}_{\mathrm{ic}}$ is the "spread" between the domestic and world price of good $\mathrm{i}$ that measures all factors that account for deviations from the LOP (trade barriers, pricing to market, non-traded goods, etc.), then we have $\mathrm{p}_{\mathrm{ic}}=\mathrm{k}_{\mathrm{ic}} \times \mathrm{S}_{\mathrm{c}} \times \mathrm{p}_{\mathrm{i}}^{*}$, with $\mathrm{k}_{\mathrm{ic}}=1$ representing no deviations. When quantities are

\footnotetext{
2 The literature on the LOP, and its close cousin purchasing power parity, is large and growing. For modern surveys, see Froot and Rogoff (1995), Lan and Ong (2003), MacDonald (2007), Rogoff (1996), Sarno and Taylor (2002), Taylor and Taylor (2004) and Taylor (2006).

${ }^{3}$ This discussion is simplified in the interest of clarity. In fact, the ICP (2008) evaluate consumption at "international prices", which are cross-country averages, expressed in terms of US dollars. Thus, strictly speaking, $p_{i}^{*}$ is not the price in the US, but the international price measured in US dollars. This simplification does not affect the logic of the argument, however.
} 
measured in terms of US dollars and prices the cost of one dollar's worth, the price of each good in the US is unity, so that $\mathrm{p}_{\mathrm{ic}}=\mathrm{k}_{\mathrm{ic}} \times \mathrm{S}_{\mathrm{c}}$, or

$$
\log \mathrm{p}_{\mathrm{ic}}=\log \mathrm{k}_{\mathrm{ic}}+\log \mathrm{S}_{\mathrm{c}} \text {. }
$$

Multiplying both sides of this equation by $\mathrm{w}_{\mathrm{ic}}$ and then summing over $\mathrm{i}=1, \ldots, \mathrm{n}$ yields

$$
\log \mathrm{P}_{\mathrm{c}}=\log \mathrm{K}_{\mathrm{c}}+\log \mathrm{S}_{\mathrm{c}},
$$

where $\log \mathrm{K}_{\mathrm{c}}=\sum_{\mathrm{i}=1}^{\mathrm{n}} \mathrm{W}_{\mathrm{ic}} \log \mathrm{k}_{\mathrm{ic}}=\sum_{\mathrm{i}=1}^{\mathrm{n}} \mathrm{W}_{\mathrm{ic}} \log \left(\mathrm{p}_{\mathrm{ic}} / \mathrm{S}_{\mathrm{c}}\right)$ is the average spread. The term $\log \mathrm{K}_{\mathrm{c}}$ can be interpreted as the degree to which the currency is mispriced: When $\log \mathrm{K}_{\mathrm{c}}>0$ domestic prices are too high in relation to world prices, and the market exchange rate overvalues the currency by $100 \times\left(K_{c}-1\right)$ percent, while it is undervalued if $\log K_{c}<0$. A sufficient condition for no currency mispricing is when each of the $n$ prices in equalised $\left(\log \mathrm{k}_{\mathrm{ic}}=0, \mathrm{i}=1, \ldots, \mathrm{n}\right)$, which could be termed the "strong form" of the LOP. The complete, or absolute, equalisation of the n prices is clearly a very stringent condition that is most unlikely to be satisfied in practice.

Subtracting both sides of equation (4) from (3) yields

$$
\log \mathrm{p}_{\mathrm{ic}}-\log \mathrm{P}_{\mathrm{c}}=\log \mathrm{k}_{\mathrm{ic}}-\log \mathrm{K}_{\mathrm{c}} \text {. }
$$

This states that the logarithmic relative price of $i$ is the deviation of its spread from the average. The "weak version" of the LOP states that domestic prices are proportional to world prices, so that $\log \mathrm{k}_{\mathrm{ic}}=\log \mathrm{K}_{\mathrm{c}}$ and, from (5), $\log \mathrm{p}_{\mathrm{ic}}-\log \mathrm{P}_{\mathrm{c}}=0, \mathrm{i}=1, \ldots, \mathrm{n}$. In this case, the price variance $\Pi_{\mathrm{c}}=0$. More generally, the (weighted) variance of departures from the LOP is

$$
\sum_{i=1}^{n} w_{i c}\left[\log k_{i c}-\log K_{c}\right]^{2}=\sum_{i=1}^{n} w_{i c}\left[\log \left(p_{i c} / S_{c}\right)-\left(\log P_{c} / S_{c}\right)\right]^{2}=\Pi_{c}
$$

where $\Pi_{c}$ is the variance of relative prices (2). It can, therefore, be seen that a measure of departure from the LOP in its weak form is the degree of dispersion of relative prices. Moreover, as the price variance involves relative prices, for which currency units play no role, the variance is comparable across countries.

\section{Incomes and Prices in 132 Countries}

We use data on the prices and per capita consumption of 12 commodities in 132 countries, from the International Comparison Program (2008). Tables 1 and 2 list the countries and commodities. ${ }^{4}$ Countries are listed in terms of decreasing real income per capita, defined as the total real volume of per capita consumption measured in US dollars, scaled such that US=100. As can be seen, there is great variation in income, which ranges from 100 in the US, the richest country, to 0.4 in the Democratic Republic of Congo, the poorest. Table 1 also contains the standard deviations of

\footnotetext{
${ }^{4}$ For details of the data, see Appendix A1.
} 
the prices $\sqrt{\Pi_{c}}$. There is a broad tendency for the standard deviation to be higher in low income countries - from the last two entries of the last column of the table, the standard deviation of prices is about twice as high in the poor group of countries as compared to the rich (61 vs 30 percent), but other than that, there is no clear pattern, most likely because noise in the price data is necessarily attenuated in any measure of dispersion.

In addition to the dispersion of $\mathrm{n}$ prices within a country, it is of interest to consider the dispersion across $\mathrm{C}$ countries,

$$
\Pi=\frac{1}{\mathrm{C}} \sum_{\mathrm{c}=1}^{\mathrm{C}} \sum_{\mathrm{i}=1}^{\mathrm{n}} \mathrm{w}_{\mathrm{ic}}\left[\log \mathrm{p}_{\mathrm{ic}}-\log \mathrm{P}_{\mathrm{c}}-\frac{1}{\mathrm{C}} \sum_{\mathrm{c}=1 \mathrm{i}=1}^{\mathrm{C}} \sum_{\mathrm{ic}}^{\mathrm{n}} \mathrm{w}_{\mathrm{ic}}\left(\log \mathrm{p}_{\mathrm{ic}}-\log \mathrm{P}_{\mathrm{c}}\right)\right]^{2} \text {. }
$$

Here, commodities are weighted by their budget shares to reflect their relative importance, while countries are unweighted to reflect the idea that we have $\mathrm{C}$ independent readings on the structure of prices. This world variance $\Pi$ can be decomposed into within- and between-country components:

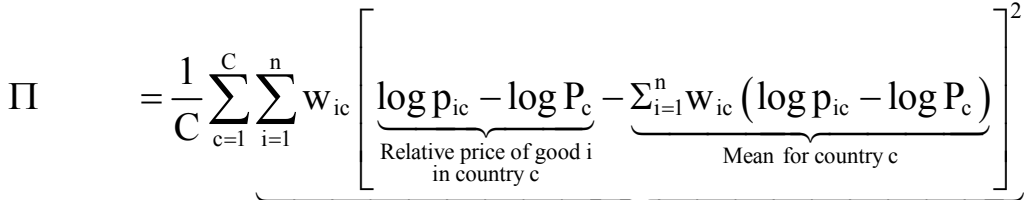

$$
\begin{aligned}
& \underbrace{\sim}_{\text {Total variance }}=\underbrace{\text { Variance for country c }}_{\text {Mean variance over countries; "within" component }}
\end{aligned}
$$

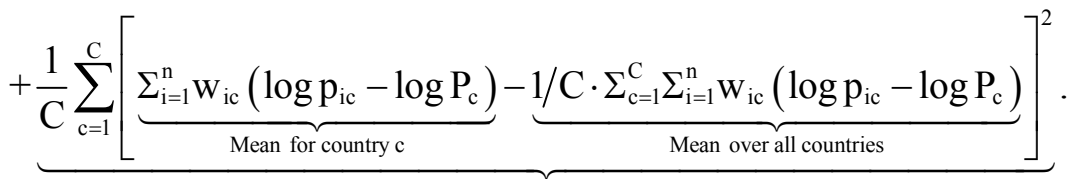

As $\sum_{\mathrm{i}=1}^{\mathrm{n}} \mathrm{W}_{\mathrm{ic}}\left(\log \mathrm{p}_{\mathrm{ic}}-\log \mathrm{P}_{\mathrm{c}}\right)=0$, the between-country variance vanishes and using equation (2), the following simple result emerges:

$$
\Pi=\frac{1}{\mathrm{C}} \cdot \sum_{\mathrm{c}=1}^{\mathrm{C}} \Pi_{\mathrm{c}} .
$$

Thus, the world variance is just the average of that in the $\mathrm{C}$ countries, which is a convenient result. Figure 1 presents histograms of relative prices of the $n=12$ goods for the two groups of countries. Consistent with the above approach, here prices are weighted by budget shares. As can be seen, prices are clearly less dispersed in the rich countries. ${ }^{5}$

Next, we investigate informally the dependence of prices on income. Let $\log \left(Q_{c} / \bar{Q}\right)$ be income in country c relative to the geometric mean income for all countries. Figure 2 plots each relative price $\log \left(\mathrm{p}_{\mathrm{ic}} / \mathrm{P}_{\mathrm{c}}\right)$ against relative income for the 132 countries. As discussed above, $\mathrm{p}_{\mathrm{ic}}$ is

\footnotetext{
${ }^{5}$ Note that the standard deviations of the histograms, corresponding to $\sqrt{\Pi}$ with $\Pi$ defined by equation (6), are close to the mean SDs given at the bottom of Table 1, but not identical. Identical results are obtained if we first square each country's SD in Table 1, average and then take the square root. That is to say, the results satisfy equation (7).
} 
the price of one US dollar's worth of good $\mathrm{i}$ in country c, while $\mathrm{P}_{\mathrm{c}}$ is the weighted geometric mean; accordingly, if $\mathrm{p}_{\mathrm{ic}} / \mathrm{P}_{\mathrm{c}}>1$, then $\mathrm{i}$ is relatively expensive in $\mathrm{c}$ and $\log \left(\mathrm{p}_{\mathrm{ic}} / \mathrm{P}_{\mathrm{c}}\right)>0$. The term "relatively more expensive" in this context means that a dollar's worth of $i$ costs more than the average over all goods. It is to be noted that as $\sum_{\mathrm{i}=1}^{12} \mathrm{w}_{\mathrm{ic}} \log \left(\mathrm{p}_{\mathrm{ic}} / \mathrm{P}_{\mathrm{c}}\right)=0$, some of the logarithmic relative prices must be positive, others negative, averaging out to zero. Panel 1 of Figure 2 indicates that food prices exhibit three patterns. First, as most of the points lie above the zero horizontal line, food is relatively expensive in the majority of countries. The other panels of the figure show that housing, health and education tend to be cheap, while clothing, transport and restaurants are expensive. Second, food prices tend to become cheaper as income rises, as indicated by the negative slope of the regression line in the panel. Third, in a number of instances there is clear visual evidence of the dependence of prices on income, a topic explored further in the next section.

\section{A Simple Model of Relative Prices}

Suppose the quantity supplied of good $i,\left(q_{i}^{s}\right)$, is a log-linear function of its relative price $\left(\mathrm{p}_{\mathrm{i}} / \mathrm{P}\right)$, while its consumption depends on the relative price and real income $(\mathrm{Q})$ :

$$
\log q_{i}^{s}=\phi_{i}^{s}+\eta_{i}^{s}\left(\log p_{i}-\log P\right), \quad \log q_{i}^{d}=\phi_{i}^{d}+\eta_{i}^{d}\left(\log p_{i}-\log P\right)+\theta_{i} \log Q,
$$

where $\phi_{i}^{s}\left(\phi_{i}^{d}\right)$ is the intercept of the supply (demand) function, $\eta_{i}^{s}>0 \quad\left(\eta_{i}^{d}<0\right)$ is the price elasticity of supply (demand) and $\theta_{\mathrm{i}}$ is the income elasticity. Market clearing implies that

$$
\log \mathrm{p}_{\mathrm{i}}-\log \mathrm{P}=\alpha_{\mathrm{i}}^{\prime}+\beta_{\mathrm{i}}^{\prime} \log \mathrm{Q}
$$

where $\alpha_{i}^{\prime}=\left(\phi_{i}^{\mathrm{d}}-\phi_{\mathrm{i}}^{\mathrm{s}}\right) / \Delta_{\mathrm{i}}$, with $\Delta_{\mathrm{i}}=\eta_{\mathrm{i}}^{\mathrm{s}}-\eta_{\mathrm{i}}^{\mathrm{d}}>0$ the excess supply elasticity, and $\beta_{\mathrm{i}}^{\prime}=\theta_{\mathrm{i}} / \Delta_{\mathrm{i}}$. This reduced form is not a completely satisfactory formulation for the following reason. If good $\mathrm{i}$ is normal, then the income elasticity $\theta_{\mathrm{i}}$ and the reduced-form income coefficient $\beta_{\mathrm{i}}^{\prime}$ are both positive. If each of the $n$ goods is normal, which is entirely possible, then equation (8) says that the impact of income growth is to increase all relative prices, which is logically impossible: As a budget-share weighted average of relative prices is zero, some would have to increase, while others decrease.

To rectify this problem, we proceed in two steps. First, we multiply both sides of equation (8) by the budget share of good $i$ and add both sides over $i=1, \ldots, n$. As $\sum_{i=1}^{n} w_{i}\left(\log p_{i}-\log P\right)=0$, we have $\mathrm{A}+\mathrm{B} \log \mathrm{Q}=0$, where $\mathrm{A}=\sum_{\mathrm{i}=1}^{\mathrm{n}} \mathrm{w}_{\mathrm{i}} \alpha_{\mathrm{i}}^{\prime}$ and $\mathrm{B}=\sum_{\mathrm{i}=1}^{\mathrm{n}} \mathrm{w}_{\mathrm{i}} \beta_{\mathrm{i}}^{\prime}$ are weighted averages of the coefficients of equation (8). Second, we subtract $A+B \log Q$ from both sides of equation (8) by then multiply both sides by $\mathrm{w}_{\mathrm{i}}$ to give

$$
\mathrm{w}_{\mathrm{i}}\left(\log \mathrm{p}_{\mathrm{i}}-\log \mathrm{P}\right)=\alpha_{\mathrm{i}}+\beta_{\mathrm{i}} \log \mathrm{Q},
$$


where $\alpha_{i}=w_{i}\left(\alpha_{i}^{\prime}-A\right)$ and $\beta_{i}=w_{i}\left(\beta_{i}^{\prime}-B\right)$ are weighted deviations from weighted means that satisfy $\sum_{\mathrm{i}=1}^{\mathrm{n}} \alpha_{\mathrm{i}}=\sum_{\mathrm{i}=1}^{\mathrm{n}} \beta_{\mathrm{i}}=0$. According to model (9), growth in income leads a rise in the relative price of good $\mathrm{i}$ if its $\beta_{\mathrm{i}}>0$. As $\mathrm{w}_{\mathrm{i}}>0$, this occurs when its $\beta_{\mathrm{i}}^{\prime}=\theta_{\mathrm{i}} /\left(\eta_{\mathrm{i}}^{\mathrm{s}}-\eta_{\mathrm{i}}^{\mathrm{d}}\right)$ is larger than the average, B. Accordingly, income growth increases the relative price of $i$ when the ratio of its income elasticity to the excess supply elasticity is larger than average, and vice versa. Dividing both sides of equation (9) by $\mathrm{w}_{\mathrm{i}}$, it can be seen that $\beta_{\mathrm{i}} / \mathrm{w}_{\mathrm{i}}$ is the income elasticity of the relative price of good $\mathrm{i}$ and that a budget share weighted-average of these elasticties, $\sum_{\mathrm{i}=1}^{\mathrm{n}} \mathrm{w}_{\mathrm{i}}\left(\beta_{\mathrm{i}} / \mathrm{w}_{\mathrm{i}}\right)$, is zero, as required.

To analyse further the workings of model (9), suppose that the excess supply elasticity is the same for each commodity: $\eta_{i}^{\mathrm{s}}-\eta_{\mathrm{i}}^{\mathrm{d}}=\Delta_{\mathrm{i}}=\Delta>0$. The income coefficient in (9) then takes the form

$$
\beta_{\mathrm{i}}=\frac{1}{\Delta} \mathrm{w}_{\mathrm{i}}\left(\theta_{\mathrm{i}}-\sum_{\mathrm{j}=1}^{\mathrm{n}} \mathrm{w}_{\mathrm{j}} \theta_{\mathrm{j}}\right)=\frac{1}{\Delta} \mathrm{w}_{\mathrm{i}}\left(\theta_{\mathrm{i}}-1\right),
$$

where the second step follows from the requirement that a budget-share weighted average of the income elasticities is unity. As $1 / \Delta$ and $\mathrm{w}_{\mathrm{i}}$ are both positive, equation (10) reveals that the sign of $\beta_{\mathrm{i}}$ for goods that are luxuries $\left(\theta_{\mathrm{i}}>1\right)$ is positive and negative for necessities $\left(\theta_{\mathrm{i}}<1\right)$. Thus, under the stated conditions, income growth increases the relative prices of luxuries and decreases those of necessities, which is perfectly reasonable.

The variance of income elasticities of the relative prices is $\sum_{\mathrm{i}=1}^{\mathrm{n}} \mathrm{w}_{\mathrm{i}}\left(\beta_{\mathrm{i}} / \mathrm{w}_{\mathrm{i}}\right)^{2}=\sum_{\mathrm{i}=1}^{\mathrm{n}} \beta_{\mathrm{i}}^{2} / \mathrm{w}_{\mathrm{i}}$, which is a cross-commodity weighted variance and is exactly analogous to the price variance (2). From definition (10), this variance takes the form

$$
\sum_{\mathrm{i}=1}^{\mathrm{n}} \frac{\beta_{\mathrm{i}}^{2}}{\mathrm{w}_{\mathrm{i}}}=\frac{1}{\Delta^{2}} \sum_{\mathrm{i}=1}^{\mathrm{n}} \mathrm{w}_{\mathrm{i}}\left(\theta_{\mathrm{i}}-1\right)^{2} .
$$

As a budget-share weighted mean of the income elasticities is unity, their weighted variance is $\sum_{\mathrm{i}=1}^{\mathrm{n}} \mathrm{W}_{\mathrm{i}}\left(\theta_{\mathrm{i}}-1\right)^{2}$. This is the third cross-commodity variance that we have encountered. Equation (11) shows that the variance of the income elasticities of prices, $\beta_{\mathrm{i}} / \mathrm{w}_{\mathrm{i}}$, is proportional to the variance of the income elasticities of demand, $\theta_{i}$, with proportionality factor $1 / \Delta^{2}$. A greater diversity of the goods implies a larger dispersion of income elasticities and, from (11), a larger variability of the price elasticities. For example, when all goods are the same, the income elasticities are all unity and there is no dispersion among the price elasticities (each $\beta_{\mathrm{i}}=0$, so relative prices are independent of income).

We apply model (9) to the 12 commodities and 132 countries discussed in the previous section. To do this, we make three adjustments. First, to allow for excluded factors, we add a zero- 
mean disturbance term for good $\mathrm{i}$ and country $\mathrm{c}, \varepsilon_{\mathrm{ic}}$, with $\mathrm{E}\left(\varepsilon_{\mathrm{ic}}\right)^{2}=\sigma_{\mathrm{i}}^{2}$. Second, we recognise that there may be systematic differences in pricing patterns in rich and poor countries. For example, rich economies may have access to more advanced technologies, leading to lower costs of production. This implies a larger intercept of the supply function, $\phi_{i}^{\mathrm{s}}$, for those countries, which has a consequential impact on the intercept $\alpha_{i}$ in model (9). To allow for this possibility, we specify that this intercept takes different values for the rich and poor groups of countries. Third, for convenience, we measure income as a deviation from the geometric mean $\overline{\mathrm{Q}}$ as was done in the previous section. Thus, we estimate a system of 12 equations, the $i^{\text {th }}$ member of which is

$$
\mathrm{w}_{\text {ic }} \log \left(\mathrm{p}_{\text {ic }} / \mathrm{P}_{\mathrm{c}}\right)=\alpha_{\mathrm{i}}+\gamma_{\mathrm{i}} \mathrm{D}_{\mathrm{c}}+\beta_{\mathrm{i}} \log \left(\mathrm{Q}_{\mathrm{c}} / \overline{\mathrm{Q}}\right)+\varepsilon_{\mathrm{ic}}, \mathrm{c}=1, \ldots, 132,
$$

where $\mathrm{D}_{\mathrm{c}}=1$ if $\mathrm{c}$ refers to a poor economy, zero otherwise.

The least-squares estimates of equation (12) for $i=1, \ldots, 12$ are given in Table 2 . These estimates (denoted by a circumflex) satisfy the aggregation constraints $\sum_{i=1}^{12} \hat{\alpha}_{i}=\sum_{i=1}^{12} \hat{\beta}_{i}=\sum_{i=1}^{12} \hat{\gamma}_{i}=0$. As can be seen, 5 of the 12 coefficients of the poor-country dummy are significant, especially those for clothing and education; these coefficients indicate that in these countries clothing is more expensive and education cheaper, when incomes are held constant. The income coefficient of food is negative and highly significant, so that food becomes cheaper as affluence rises. As food is a necessity, the negative sign of this coefficient agrees with the discussion below equation (10). The third last column of the table shows that the income elasticity of the price of food is -0.19 , so a doubling of income leads to approximately a 20-percent decline in prices. The largest income elasticity is 0.18 for housing prices (clothing is a close second).

Table 3 explores relation (10) by presenting the income elasticities of demand implied by the estimates of $\beta_{\mathrm{i}}$ from Table 2 . To do this, the excess supply elasticity $\Delta$ is required and in columns 35 we use three "central" values, 1, 2 and 3. The implied elasticities can then be compared to directly estimated ones (derived from Clements and Chen, 2010, with the same data), which are given in column 6. Although the agreement is not exact, the implied elasticities of column 4, corresponding to $\Delta=2$, seem to be closest, especially for the important case of food: For this good, here the implied income elasticity is 0.62 , which is close to the estimated value of 0.66 . The excess supply elasticity of $\Delta=2$ is consistent with the supply and demand elasticities being 1 and -1 , respectively. As these computations are based on the simplifying assumption that the excess supply elasticities are the same for all goods, the results should not be taken to be hard and fast. Nonetheless, the not unreasonable agreement between the implied and estimated elasticities can be interpreted as providing some reassurance that the pricing model (12) makes economic sense. 


\section{6. $\quad$ Price Dispersion and Income}

The parameter $\beta_{\mathrm{i}}$ in model (12) represents the sensitivity of the relative price of good $\mathrm{i}$ to changes in income. This dependence of prices means that income has a systematic impact on price dispersion. Using the pricing equations to analyse dispersion has the effect of eliminating much of the noise in the variance of prices and gives rises to several interesting concepts including the value of income that leads to a minimum variance (MV), as well as variance-equivalent incomes. This and the next section peruse these issues.

\section{Dispersion Quadratic in Income}

We divide both sides of equation (12) by $\mathrm{w}_{\mathrm{ic}}$ and then substitute the expression for the relative price of good $i, \log p_{i c}-\log P_{c}$, into the definition of the variance (2). Taking the expectation and writing $\mathrm{y}_{\mathrm{c}}=\mathrm{E}\left(\Pi_{\mathrm{c}}\right)$ and $\mathrm{x}_{\mathrm{c}}=\log \left(\mathrm{Q}_{\mathrm{c}} / \overline{\mathrm{Q}}\right)$, we obtain an expression for the dispersion of relative prices that is quadratic in income:

$$
\mathrm{y}_{\mathrm{c}}=\lambda_{0}+\lambda_{1} \mathrm{x}_{\mathrm{c}}+\lambda_{2} \mathrm{x}_{\mathrm{c}}^{2}, \quad \text { with } \lambda_{0}=\sum_{\mathrm{i}=1}^{12} \frac{\tilde{\alpha}_{\mathrm{i}}^{2}+\sigma_{\mathrm{i}}^{2}}{\mathrm{w}_{\mathrm{ic}}}, \lambda_{1}=\sum_{\mathrm{i}=1}^{12} \frac{2 \tilde{\alpha}_{\mathrm{i}} \beta_{\mathrm{i}}}{\mathrm{w}_{\mathrm{ic}}} \text { and } \lambda_{2}=\sum_{\mathrm{i}=1}^{12} \frac{\beta_{\mathrm{i}}^{2}}{\mathrm{w}_{\mathrm{ic}}},
$$

where $\tilde{\alpha}_{i}=\alpha_{i}+\gamma_{i} D_{c}$ is the intercept of the pricing equation (12) for good $i$ in country $\mathrm{c}$ and $\sigma_{\mathrm{i}}^{2}=\mathrm{E}\left(\varepsilon_{\mathrm{ic}}\right)^{2}$ is the variance of the disturbance term of that equation. To implement equation (13), we use the estimates of Table 2 and the shares of countries that are representative of the poor and rich groups of countries. Table 4 and Figure 3 present the results, to be discussed in detail below.

\section{Meanland and MV Income}

As income is measured relative to the mean, the intercept in equation (13), $\lambda_{0}$, represents the variance of prices corresponding to mean income. This is dispersion in "Meanland", the hypothetical country at the centre of the world with mean income. As dy/dx $=\lambda_{1}+2 \lambda_{2} x_{c}$, and $\lambda_{2}>0$, $\mathrm{x}^{*}=-\lambda_{1} / 2 \lambda_{2}$ is the variance-minimising value of income. In terms of the basic parameters of equation (13), this MV income takes the form

$$
\log \frac{\mathrm{Q}^{*}}{\overline{\mathrm{Q}}}=-\sum_{\mathrm{i}=1}^{12} \kappa_{\mathrm{i}} \frac{\tilde{\alpha}_{\mathrm{i}}}{\beta_{\mathrm{i}}}, \text { with } \kappa_{\mathrm{i}}=\frac{\beta_{\mathrm{i}}^{2} / \mathrm{w}_{\mathrm{ic}}}{\sum_{\mathrm{i}=1}^{12} \beta_{\mathrm{i}}^{2} / \mathrm{w}_{\mathrm{ic}}}>0, \sum_{\mathrm{i}=1}^{12} \kappa_{\mathrm{i}}=1
$$

Thus, MV income is a weighted average of ratios of the intercept to the slope in equation (12), with the signs changed, $-\tilde{\alpha}_{1} / \beta_{1}, \ldots,-\tilde{\alpha}_{12} / \beta_{12}$. The weight for good $\mathrm{i}$ in (14), $\kappa_{\mathrm{i}}$, is proportional to $\beta_{\mathrm{i}}^{2} / \mathrm{w}_{\mathrm{ic}}=\mathrm{w}_{\mathrm{ic}}\left(\beta_{\mathrm{i}} / \mathrm{w}_{\mathrm{ic}}\right)^{2}$, which is the square of the income elasticity of the relative price of $\mathrm{i}$, weighted by its share $\mathrm{w}_{\mathrm{ic}}$. In view of the discussion above result (11), $\kappa_{\mathrm{i}}$ is proportional to the contribution of the good in question to the variance of the income elasticities of the relative prices. 
From (11), $\kappa_{\mathrm{i}}$ is also proportional to the contribution of good $\mathrm{i}$ to the variance of the income elasticities of demand, under the condition that the excess supply elasticity is the same for each good.

Another interesting way to express the quadratic (13) is in terms of the deviation of income from its MV value. It follows from $x^{*}=-\lambda_{1} / 2 \lambda_{2}$ that $\lambda_{2}\left(x-x^{*}\right)^{2}=\lambda_{2} x^{2}+\lambda_{1} x+\lambda_{1}^{2} / 4 \lambda_{2}$, so that equation (13) can be written as

$$
\mathrm{y}_{\mathrm{c}}=\lambda_{0}^{\prime}+\lambda_{2}\left(\mathrm{x}_{\mathrm{c}}-\mathrm{x}^{*}\right)^{2}, \text { with } \lambda_{0}^{\prime}=\lambda_{0}-\lambda_{1}^{2} / 4 \lambda_{2}
$$

This shows that when $x_{c}=x^{*}$, the variance of prices is minimised and takes the value $\lambda_{0}-\lambda_{1}^{2} / 4 \lambda_{2}$. As $\lambda_{2}>0$, the variance is higher for all other values of income, and increases with the square of the deviation of income from MV income. In view of the logarithmic formulation, this deviation is the difference of country c's income from the MV value, $\log \left(Q_{c} / Q^{*}\right)$. The excess of the variance over its minimum is $\mathrm{y}_{\mathrm{c}}-\lambda_{0}^{\prime}$; the income elasticity of this excess is 2 .

\section{A Picture of Dispersion}

Figure 3 is a sketch of expected price dispersion against income for the rich and poor countries. As can be seen, for most values of income, dispersion for the poor is above that for the rich. But as the two curves are not parallel, they intersect at the point A and for incomes below this critical value, dispersion in the rich countries exceeds that of the poor. Relative income at this point is

$$
\frac{-\left(\lambda_{1}^{\mathrm{P}}-\lambda_{1}^{\mathrm{R}}\right) \pm \sqrt{\left(\lambda_{1}^{\mathrm{P}}-\lambda_{1}^{\mathrm{R}}\right)^{2}-4\left(\lambda_{2}^{\mathrm{P}}-\lambda_{2}^{\mathrm{R}}\right)\left(\lambda_{0}^{\mathrm{P}}-\lambda_{0}^{\mathrm{R}}\right)}}{2\left(\lambda_{2}^{\mathrm{P}}-\lambda_{2}^{\mathrm{R}}\right)}
$$

where $\lambda_{i}^{g}$ is the quadratic coefficient of order $i$ in equation (13) for country group $g(g=R, P$, for rich, poor). In the figure, we use the positive root in (15) as that is closest to mean income.

The point of intersection of the curve with the vertical axis is dispersion in Meanland. This is $B_{P}$ for the poor and $B_{R}$ for the rich, with $B_{P}>B_{R}$, reflecting again that on average dispersion is higher in poorer countries. The minimum-variance points are $C_{P}$ and $C_{R}$, which show that for rich countries as compared to the poor (i) this variance is lower; and (ii) the corresponding income is higher $\left(C_{R}\right.$ lies to the right of $\left.C_{P}\right)$. In terms of the quadratic coefficients, the points of intersection with the vertical axis are $B_{P}=\lambda_{0}^{P}$ and $B_{R}=\lambda_{0}^{R}$, so these coefficients determine the overall "height" of each curve. The sensitivity of dispersion to variations in income is given by the slope of the quadratic. This slope is expressed in terms of the change in the variance for a one-percent increase in income; the income elasticity of the variance (the slope divided by the variance) is proportional to 
this slope. For country group $\mathrm{g}(\mathrm{g}=\mathrm{R}, \mathrm{P})$, the slope is $\lambda_{1}^{\mathrm{g}}+2 \lambda_{2}^{\mathrm{g}} \log \left(\mathrm{Q}^{\mathrm{c}} / \overline{\mathrm{Q}}\right)$. Thus, for income less than $\mathrm{MV}$ in the poor countries (given by the point $\mathrm{C}_{\mathrm{P}}$ in the figure), the difference in the slopes between the two groups, $\left(\lambda_{1}^{\mathrm{R}}-\lambda_{1}^{\mathrm{P}}\right)+2\left(\lambda_{2}^{\mathrm{R}}-\lambda_{2}^{\mathrm{P}}\right) \log \left(\mathrm{Q}^{\mathrm{c}} / \overline{\mathrm{Q}}\right)$, is always negative. This establishes that in this range, a proportionate increase in income decreases dispersion by more in the rich countries than in the poor.

Finally, the change in the income sensitivity of dispersion is $2 \lambda_{2}$, which is a measure of the curvature of the quadratic. It follows from equations (10), (11) and (13) that the ratio of this coefficient for the rich to that for the poor is the ratio of the variances of the income elasticities of demand:

$$
\frac{\lambda_{2}^{\mathrm{R}}}{\lambda_{2}^{\mathrm{P}}}=\frac{\mathrm{d}(\text { income sensitivity of dispersion in rich })}{\mathrm{d}(\text { income sensitivity of dispersion in poor })}=\frac{\text { variance of income elasticities in rich }}{\text { variance of income elasticities in poor }} .
$$

This result holds under the condition that the excess supply elasticities are the same. From column 2 of Table 4, the estimate of $\lambda_{2}^{R}$ is almost 40 percent larger than that for the poor, implying that there is substantially more diversity among the income elasticities of demand for the rich as compared to the poor. Identifying the differences in goods in the basket by the dispersion of the income elasticties of demand, result (16) agrees with the idea that for the rich, consumption patterns are more diversified and relatively less intensive in food in particular (Engel's law).

\section{More on Meanland and MV Income}

The estimates of the zero-order coefficient in the quadratic (13), $\lambda_{0}$, contained in column 4 of Table 4, are 0.33 and 0.26 for the poor and rich countries, respectively. Thus, dispersion at mean income is $\sqrt{0.33}=0.57$ and $\sqrt{0.26}=0.51$, or about 57 and 51 percent for the poor and rich. The last two entries in this column of the table establish that these values are significantly different.

Column 5 of Table 4 reveals that in the poor (rich) countries, variance is a minimum when income is about 132 (166) percent above the mean. The last two entries in this column show that the difference between these two income values is significant. From column 6 , the minimum variance is 29 (17) percent for the poor (rich), and again this difference is significant. The next several columns indicate that Greece has income closest to the minimum-variance for the poor, while Iceland plays this role for the rich.

Equation (14) defines MV income as a weighted average of ratios of the intercept to slope coefficients (with the signs changed) in the pricing model (12). This income can thus be decomposed 
commodity-wise, as in Table 5. This shows that for both groups of countries, food and housing are the dominant contributors to MV income. ${ }^{6}$

\section{Dispersion-Equivalent Income}

As price dispersion depends on income, it is natural to ask, what change in income has the effect of equalising dispersion? We call this change "dispersion-equivalent income" (DEI). This section investigates the nature of DEI and applies the idea to the two groups of countries.

As discussed above, dispersion in the poor countries is higher than in the rich and, usually, dispersion falls as income rises. These two characteristics are only satisfied in the shaded region of Figure 4. The left-hand boundary of the region is defined by the intersection of the two curves, where income is $\mathrm{x}_{1}$; for incomes below this value, dispersion of the rich exceeds that of the poor. The right-hand boundary of the region corresponds to the minimum point for the poor, associated with income $\mathrm{x}_{2}$; when income exceeds $\mathrm{x}_{2}$, dispersion in the rich group continues to fall (which is satisfactory), but that for the poor rises (not satisfactory). Within the shaded region, we can ask, by how much does income of the rich need to be lowered to eliminate the difference in dispersion? Consider, for example, the case when income for each group is $\mathrm{x}_{3}$. Here, dispersion in the two groups is equalised when income of the rich is lowered by $\Delta \mathrm{x}>0$ to $\mathrm{x}_{3}-\Delta \mathrm{x}$. This $\Delta \mathrm{x}$ is DEI corresponding to $\mathrm{x}_{3}$.

In the above, we commenced with the poor and then determined the adjustment of the income of the rich required to increase their dispersion so that it was equal to the poor's; in this sense, the poor are the base group. We could just as well reverse things and start with the rich. Thus, when the rich's income is $x_{3}-\Delta x$, by how much does the poor's income need to be increased? Answer: the same $\Delta \mathrm{x}$, which establishes that the analysis is symmetric with respect to the base group. However, there is an additional consideration when we start with the rich: A positive DEI exists only within the smaller, cross-hatched sub region of Figure 4, where income falls in the range $\mathrm{x}_{1} \leq \mathrm{x} \leq \mathrm{x}_{4}$. The new boundary value $\mathrm{x}_{4}$ is income when dispersion of the rich equals the minimum value for the poor. For

\footnotetext{
${ }^{6}$ It should be noted that we explored two extensions to and checks on the results. First, some of the relative prices for Lebanon, Iran and Georgia seem to be outlying observations. As a robustness check, we redid the results of Table 4 with the data for these three countries omitted; this had only a very marginal impact on the results. Second, in Table 2 poor countries were distinguished from the rich by an intercept dummy. This treatment was re-examined graphically by plotting each relative price against income and then fitting separate regression lines for the rich and poor groups of countries. For most commodities, the scatterplots show something approximating an intercept shift. Clothing and furnishings are exceptions to this general rule, but as these goods each absorb about 5 percent of the budget for an average country, they are unlikely to substantially affect the overall results which entail weighting by budget shares. However, when pricing model (12) was estimated separately for the two groups of countries and the quadratic (13) reevaluated, the results do change. There may be a case to keep the two groups separate, but due to the relatively small sample size for the rich, it is not possible to be hard and fast on this issue. For details, see Appendix A1.
} 
income exceeding $\mathrm{x}_{4}$, no addition to income of the poor will equalise dispersion. To summarise, it is legitimate to use either the rich or the poor as the base group for the analysis of DEI, but given the way the two curves are drawn in Figure 4, the feasible range of income is smaller when the rich are used for this purpose.

As is clear from Figure 4, the nonlinearities mean that DEI varies with income; as will be shown below, DEI is quadratic in income. This is further illustrated by Figure 5, which plots DEI against income. ${ }^{7}$ The curve to the right, which refers to the case in which the base is the poor, is derived from the left curve (base = rich) by adding the DEI for the rich, the height of their curve, to income of the rich to obtain the income of the poor. For example, when income of the rich is $\mathrm{x}_{3}-\Delta \mathrm{x}, \mathrm{DEI}=\Delta \mathrm{x}$. As the point $\mathrm{A}$ on the curve for the rich lies above the $45^{\circ}$ line, $\Delta \mathrm{x}>\left|\mathrm{x}_{3}-\Delta \mathrm{x}\right|$. The associated point on the poor's curve is B, where DEI is the same $\Delta \mathrm{x}$ as before, while income is the previous value, $\mathrm{x}_{3}-\Delta \mathrm{x}$, plus DEI, $\Delta \mathrm{x}$, or $\mathrm{x}_{3}$. Figure 5 reveals three patterns in the nature of DEI. First, DEI increases with income, reflecting that the rising difference in dispersion for the rich and the poor. Second, in the range $\mathrm{x}_{1} \leq \mathrm{x} \leq \mathrm{x}_{4}$, the DEI curve for the rich lies everywhere above that for the poor. This means that when the income of the poor is increased to equalise dispersion, DEI is larger than when the rich's income is reduced. Finally, for a given income within the range $\mathrm{x}_{1} \leq \mathrm{x} \leq \mathrm{x}_{4}$, the marginal DEI, $\mathrm{d}(\mathrm{DEI}) / \mathrm{dx}$, for the rich exceeds that for the poor.

To formulate DEI algebraically, we apply equation (13) to the rich and poor groups of countries explicitly by defining the quadratic coefficients as $\lambda_{\mathrm{k}}^{\mathrm{g}}$, for $\mathrm{k}=0,1,2$ (for the order) and $\mathrm{g}=$ $\mathrm{R}, \mathrm{P}$ (for the rich and poor). Thus, we now have

$$
\begin{aligned}
& \mathrm{y}_{\mathrm{c}}=\lambda_{0}^{\mathrm{R}}+\lambda_{1}^{\mathrm{R}} \mathrm{x}_{\mathrm{c}}+\lambda_{2}^{\mathrm{R}} \mathrm{x}_{\mathrm{c}}^{2}, \text { with } \lambda_{0}^{\mathrm{R}}=\sum_{\mathrm{i}=1}^{12} \frac{\alpha_{\mathrm{i}}^{2}+\sigma_{\mathrm{i}}^{2}}{\mathrm{w}_{\mathrm{ic}}}, \lambda_{1}^{\mathrm{R}}=\sum_{\mathrm{i}=1}^{12} \frac{2 \alpha_{\mathrm{i}} \beta_{\mathrm{i}}}{\mathrm{w}_{\mathrm{ic}}} \text { and } \lambda_{2}^{\mathrm{R}}=\sum_{\mathrm{i}=1}^{12} \frac{\beta_{\mathrm{i}}^{2}}{\mathrm{w}_{\mathrm{ic}}}, \text { if } \mathrm{c} \in \text { Rich, } \\
& \mathrm{y}_{\mathrm{c}}=\lambda_{0}^{\mathrm{P}}+\lambda_{1}^{\mathrm{P}} \mathrm{x}_{\mathrm{c}}+\lambda_{2}^{\mathrm{P}} \mathrm{x}_{\mathrm{c}}^{2}, \text { with } \lambda_{0}^{\mathrm{P}}=\sum_{\mathrm{i}=1}^{12} \frac{\tilde{\alpha}_{\mathrm{i}}^{2}+\sigma_{\mathrm{i}}^{2}}{\mathrm{w}_{\mathrm{ic}}}, \lambda_{1}^{\mathrm{P}}=\sum_{\mathrm{i}=1}^{12} \frac{2 \tilde{\alpha}_{\mathrm{i}} \beta_{\mathrm{i}}}{\mathrm{w}_{\mathrm{ic}}} \text { and } \lambda_{2}^{\mathrm{P}}=\sum_{\mathrm{i}=1}^{12} \frac{\beta_{\mathrm{i}}^{2}}{\mathrm{w}_{\mathrm{ic}}}, \text { if } \mathrm{c} \in \text { Poor. }
\end{aligned}
$$

These equations for the two groups differ for two reasons. First, the zero-order coefficients contain the respective intercepts of equation (12), $\tilde{\alpha}_{i}=\alpha_{i}+\gamma_{i}$ for the poor and $\alpha_{i}$ for the rich. Second, the budget shares in the coefficients are different across countries.

Write the variance for country $\mathrm{c}$ that belongs to group $\mathrm{g}$ as a function of income as $y_{c}=f_{g}\left(x_{c}\right)$. Then, DEI, $\Delta x$, solves $f_{R}\left(x_{c}\right)=f_{P}\left(x_{c}+\Delta x\right)$. Using the above, this becomes

$$
\lambda_{0}^{\mathrm{R}}+\lambda_{1}^{\mathrm{R}} \mathrm{x}_{\mathrm{c}}+\lambda_{2}^{\mathrm{R}} \mathrm{x}_{\mathrm{c}}^{2}=\lambda_{0}^{\mathrm{P}}+\lambda_{1}^{\mathrm{P}}\left(\mathrm{x}_{\mathrm{c}}+\Delta \mathrm{x}\right)+\lambda_{2}^{\mathrm{P}}\left(\mathrm{x}_{\mathrm{c}}+\Delta \mathrm{x}\right)^{2} \text {, or } \phi_{0}+\phi_{1} \Delta \mathrm{x}+\phi_{2}(\Delta \mathrm{x})^{2}=0,
$$

\footnotetext{
${ }^{7}$ For clarity, this figure is not drawn on the same scale as Figure 4.
} 
with $\phi_{0}=\lambda_{0}^{\mathrm{P}}-\lambda_{0}^{\mathrm{R}}+\left(\lambda_{1}^{\mathrm{P}}-\lambda_{1}^{\mathrm{R}}\right) \mathrm{x}_{\mathrm{c}}+\left(\lambda_{2}^{\mathrm{P}}-\lambda_{2}^{\mathrm{R}}\right) \mathrm{x}_{\mathrm{c}}^{2}, \phi_{1}=\lambda_{1}^{\mathrm{P}}+2 \lambda_{2}^{\mathrm{P}} \mathrm{x}_{\mathrm{c}}$ and $\phi_{2}=\lambda_{2}^{\mathrm{P}}$. The roots of this equation are

$$
\Delta \mathrm{x}=\frac{-\phi_{1} \pm \sqrt{\phi_{1}^{2}-4 \phi_{2} \phi_{0}}}{2 \phi_{2}} .
$$

We evaluate this equation with the quadratic coefficients of Table 4 and use the smaller root. When the rich is used as the base for the comparison, the admissible range of income is $-1.11 \leq \mathrm{x} \leq-0.26$, which is equivalent to the poor's income falling within the range 33-77 percent of the mean. Table 6 gives the values of DEI and as can be seen, it is sensitive to income: DEI is 3 percent of income when the poor's income is 33 percent of the mean, while DEI is 61 percent when income rises to 56 percent of the mean.

\section{The Cost of Dispersion}

Consider two countries with the same income and suppose that because of flawed institutions and/or policies, price dispersion is higher in one than the other. This will distort economic decisions and impose a welfare cost on the high-dispersion economy. In this section, we analyse the welfare implications of the higher dispersion in the poor group of countries. This analysis takes place under several simplified conditions: The excess dispersion is taken to be distortionary, and the implications are confined to consumption in the context of a simple demand. For these reasons, the results that follow should be viewed as illustrating the issues involved, rather than representing precise quantification.

Suppose distortions change the vector of $\mathrm{n}$ prices by $\Delta \mathbf{p}$, which leads to changes in consumption of $\mathbf{S} \Delta \mathbf{p}$, where $\mathbf{S}$ is the substitution matrix. The associated welfare cost can be expressed as $\mathrm{W}=-\frac{1}{2} \Delta \mathbf{p}^{\prime} \mathbf{S} \Delta \mathbf{p}$ (Harberger, 1964). It can be shown that the welfare cost as a fraction of income $(\mathrm{M})$ is

$$
\frac{\mathrm{W}}{\mathrm{M}}=-\frac{\kappa}{2} \Pi,
$$

where $\kappa<0$ is the negative of the elasticity of substitution and $\Pi$ is price dispersion $(2) .{ }^{8}$ In words, the welfare cost is proportional to the price variance, where the proportionality factor is one-half of the elasticity of substitution. The cost of the higher dispersion in the poor, as compared to the rich, is then $\Delta(\mathrm{W} / \mathrm{M})=-(\kappa / 2) \Delta \Pi$, where $\Delta \Pi>0$ is the increase in dispersion.

In view of the broad nature of the commodity groups, there is not likely to be much substitutability between them, so a low value of the elasticity of substitution would be appropriate. Thus, if this elasticity is one-half, then the welfare cost is one-quarter of the increase in the variance.

\footnotetext{
${ }^{8}$ For the derivation of result (18), based on Selvanathan's (1985) model, see Appendix A2.
} 
One way to measure $\Delta \Pi$ is by the increase in the variance at mean income, which from the last entry of column 4 of Table 4 is $7.95\left(\times 100^{-1}\right)$. Thus, the welfare cost for the poor, expressed as a proportion of their income, is $7.95 / 4 \approx 2$ percentage points higher than that for the rich. Although apparently quite modest, for some countries this figure could be near one year's economic growth. As the cost repeats itself each year, the implication is that in some cases the elimination of the underlying distortions could lead to a non-trivial acceleration of growth. But as our estimate of the cost depends on the demand structure used, the value of the elasticity of substitution and exactly how the increase in dispersion is measured, it should be clear that it provides only a back-of-the-envelope indication of the order of magnitude involved.

\section{Concluding Comments}

This paper has dealt with the theory and measurement of differences in income and prices across countries. Using the data on the $130+$ countries recently published by the International Comparison Program, the distribution of prices within poor countries was found to be substantially more dispersed than that in the rich group. As the prices of some commodities are strongly related to income, we developed a simple analytical model to understand this phenomenon. This model provides a novel link between prices and the income-sensitivity of consumption patterns. This approach implies that price dispersion is quadratic in income and gives rise to several interesting concepts including the value of income that minimises dispersion, as well as dispersion-equivalent income. Finally, we carried out some illustrative calculations regarding the welfare cost of dispersion. In summary, this framework permits an understanding of price dispersion, the identification of its determinants and provides useful new concepts.

Rather than reiterating the findings in detail, we conclude with some broader issues raised by the analysis. If higher dispersion entails a welfare cost, we could ask what is the source of the distortion? If it were the result of bad policy (taxes, import tariffs, misaligned exchange rate, etc.), or mispricing of factor inputs (under-priced natural resources, too high labour costs due to unions, etc.), then a genuine distortion exists that imposes human-made damage on the economy, as measured by the welfare cost. But if the distribution of prices is more dispersed because of natural factors such as climate, geography or factor endowments, then there is no distortion. The associated cost is not a welfare cost as usually understood, but a cost that simply has to be lived with.

What if the higher dispersion results from poor infrastructure such as low-quality ports, roads and telecommunications? Here, the higher costs could result in higher prices at home for imported commodities and lower prices of those goods that are exported, thus increasing overall dispersion. Without further information, it is not clear if this is a distortion that carries a welfare cost; for example, a country's infrastructure may be inferior by international standards, it may still be 
appropriate if there is a limited pool of investable funds. Another difficulty occurs when the lack of assess to modern technology causes the costs of certain goods to be higher than would otherwise be the case, while others are lower. The interpretation of the higher price dispersion is unclear here also. A final broader issue relates to how the economy responds to shocks of all kind. When the economy is better able to adjust to shocks, supply and demand schedules are more price elastic and relative prices are more stable. Accordingly, for a given disturbance, such as an oil-price shock, price dispersion will be lower due to the greater flexibility of the economy, other things remaining unchanged.

\section{$\underline{\text { References }}$}

Balassa, B. (1964). "The Purchasing Power Parity Doctrine: A Reappraisal.” Journal of Political Economy 72: 584-96.

Bergin, P. R., R. Glick and A. M. Taylor (2006). "Productivity, Tradability and the Long-Run Price Puzzle." Journal of Monetary Economics 53: 2041-66.

Bhagwati, J. N. (1984). "Why are Services Cheaper in the Poor Countries?" Economic Journal 94: 279-86.

Clements, K. W. and D. Chen (2010). "Affluence and Food: A Simple Way to Infer Incomes." American Journal of Agricultural Economics 92 (4): 909-26.

Cuthbert, J. (2009). "Implicit Data Structures and Properties of Selected Additive Indices." In D. S. P. Rao (Ed) Purchasing Power Parities of Currencies: Recent Advances in Methods and Approaches. Cheltenham, UK and Northampton, MA, USA: Edward Elgar. Pp. 160-80.

Diewert, W. E. (2009). "Similarity Indexes and Criteria for Spatial Linking." In D. S. P. Rao (Ed) Purchasing Power Parities of Currencies: Recent Advances in Methods and Approaches. Cheltenham, UK and Northampton, MA, USA: Edward Elgar. Pp. 183-216.

Froot, K. A., and K. Rogoff (1995). "Perspectives on PPP and Long-Run Real Exchange Rates." In G. Grossman and K. Rogoff (Eds) Handbook of International Economics. Volume 3. Amsterdam: North-Holland. Pp. 1647-88.

Harberger, A. C. (1964). "Taxation, Resource Allocation, and Welfare." In National Bureau of Economic Research and The Brookings Institution, The Role of Direct and Indirect Taxes in the Federal Revenue System. Princeton: Princeton University Press. Pp. 25-75.

Hsieh, C-T, and P. J. Klenow (2007). "Relative Prices and Relative Prosperity." American Economic Review 97: 562-85.

International Comparison Program (2008). "Global Purchasing Power Parities and Real Expenditures." Available at http://www.worldbank.org.

Kravis, I. B., A. Heston and R. Summers (1982). World Product and Income: International Comparisons of Real Gross Product. Baltimore and London: Johns Hopkins University Press for the World Bank.

Lan, Y., and L. L. Ong (2003). "The Growing Evidence on Purchasing Power Parity.” In L. L. Ong The Big Mac Index: Applications of Purchasing Power Parity. UK: Palgrave MacMillan. Pp. 29-50.

MacDonald, R. (2007). Exchange Rate Economics: Theories and Evidence. Milton Park, UK: Routledge.

Rogoff, K. (1996). “The Purchasing Power Parity Puzzle.” Journal of Economic Literature 34: 64768.

Samuelson, P. A. (1964). "Theoretical Notes on Trade Problems." Review of Economics and Statistics 46: 145-54. 
Sarno, L., and M. P. Taylor (2002). The Economics of Exchange Rates. Cambridge: Cambridge University Press.

Selvanathan, E. A. (1985). “An Even Simpler Differential Demand System.” Economics Letters 19: $343-47$.

Sergeev, S. (2009). “Aggregation Methods Based on Structural International Prices.” In D. S. P. Rao (Ed) Purchasing Power Parities of Currencies: Recent Advances in Methods and Approaches. Cheltenham, UK and Northampton, MA, USA: Edward Elgar. Pp. 274-97.

Simonovska, I. (2010). "Income Differences and Prices of Tradables." Working Paper 16233, NBER.

Summers, R., and A. Heston (1991). "The Penn World Table (Mark 5): An Expanded Set of International Comparisons, 1950-1988." Quarterly Journal of Economics 106: 327-68.

Taylor, A. M., and M. P. Taylor (2004). "The Purchasing Power Parity Debate." Journal of Economic Perspectives 18: 135-58.

Taylor, M. P. (2006). "Real Exchange Rates and Purchasing Power Parity: Mean Reversion in Economic Thought." Applied Financial Economics 16: 1-17.

Theil, H. (1967). Economics and Information Theory. Amsterdam and Chicago: North-Holland and Rand McNally.

Theil, H. (1996). Studies in Global Econometrics. Dordrecht, Boston, London: Kluwer Academic Publishers.

Thomas, C., J. Marquez, S. Fahle and J. Coonan (2011). "International Relative Price Levels: An Empirical Analysis." In D. S. Prasada Rao and F. Vogel (Eds), Measuring the Size of the World Economy: A Framework, Methodology and Results from the International Comparison Program (ICP). Washington DC: World Bank. Forthcoming. 
TABLE 1

INCOMES AND DISPERSION OF PRICES, 132 COUNTRIES IN 2005

\begin{tabular}{|c|c|c|c|c|c|c|c|c|}
\hline Country & $\begin{array}{l}\text { Income } \\
\text { p.c. }\end{array}$ & $\begin{array}{l}\text { SD of } \\
\text { prices }\end{array}$ & Country & $\begin{array}{l}\text { Income } \\
\text { p.c. }\end{array}$ & $\begin{array}{l}\text { SD of } \\
\text { prices }\end{array}$ & Country & $\begin{array}{l}\text { Income } \\
\text { p.c. }\end{array}$ & $\begin{array}{l}\text { SD of } \\
\text { prices }\end{array}$ \\
\hline 1. United States & 100.0 & 0.0 & 46. Mexico & 28.7 & 35.3 & 91. Kyrgyz & 8.0 & 88.3 \\
\hline 2. Luxembourg & 92.2 & 16.8 & 47. Belarus & 27.3 & 73.1 & 92. Sri Lanka & 7.9 & 55.8 \\
\hline 3. Iceland & 80.7 & 29.1 & 48. Kazakhstan & 26.5 & 72.9 & 93. Iraq & 7.8 & 64.6 \\
\hline 4. Norway & 77.7 & 31.3 & 49. Mauritius & 26.3 & 55.3 & 94. Mongolia & 7.7 & 81.9 \\
\hline 5. United Kingdom & 76.9 & 26.7 & 50. Russia & 26.3 & 63.1 & 95. Philippines & 7.5 & 55.9 \\
\hline 6. Austria & 76.4 & 24.9 & 51. Bulgaria & 26.1 & 62.8 & 96. Indonesia & 7.4 & 50.9 \\
\hline 7. Switzerland & 74.6 & 18.9 & 52. Iran & 25.2 & 69.1 & 97. Pakistan & 7.3 & 68.1 \\
\hline 8. Canada & 74.4 & 21.8 & 53. Romania & 24.4 & 53.5 & 98. Morocco & 7.2 & 42.8 \\
\hline 9. Netherlands & 72.4 & 25.1 & 54. Oman & 24.2 & 37.7 & 99. Lesotho & 7.1 & 76.8 \\
\hline 10. Sweden & 72.0 & 25.3 & 55. Argentina & 24.0 & 42.9 & 100. China & 7.0 & 66.6 \\
\hline 11. France & 71.5 & 23.0 & 56. Serbia & 23.7 & 58.3 & 101. Vietnam & 6.8 & 91.3 \\
\hline 12. Australia & 70.6 & 23.3 & 57. Saudi Arabia & 23.6 & 36.6 & 102. India & 5.5 & 70.8 \\
\hline 13. Denmark & 69.8 & 25.2 & 58. Chile & 23.3 & 36.0 & 103. Cambodia & 5.3 & 79.8 \\
\hline 14. Belgium & 68.4 & 22.5 & 59. Uruguay & 22.1 & 36.3 & 104. Yemen & 5.2 & 57.7 \\
\hline 15. Germany & 67.5 & 21.3 & 60. Bosnia Herz. & 21.9 & 55.9 & 105. Sudan & 4.5 & 46.2 \\
\hline 16. Hong Kong & 66.3 & 38.4 & 61. Macedonia & 20.5 & 60.6 & 106. Lao & 4.4 & 82.1 \\
\hline 17. Ireland & 66.2 & 24.6 & 62. Ukraine & 19.8 & 78.8 & 107. Djibouti & 4.4 & 70.0 \\
\hline 18. Japan & 66.0 & 35.6 & 63. South Africa & 19.3 & 41.7 & 108. Kenya & 4.3 & 69.4 \\
\hline 19. Taiwan & 64.5 & 56.0 & 64. Malaysia & 19.3 & 51.6 & 109. Sao Tome & 4.3 & 62.6 \\
\hline 20. Cyprus & 63.4 & 33.7 & 65. Turkey & 18.9 & 51.3 & 110. Congo, R. & 4.1 & 81.9 \\
\hline 21. Finland & 63.0 & 24.6 & 66. Montenegro & 18.7 & 55.8 & 111. Cameroon & 4.0 & 52.8 \\
\hline 22. Spain & 61.9 & 28.5 & 67. Brazil & 18.7 & 39.8 & 112. Nigeria & 4.0 & 76.1 \\
\hline 23. Italy & 61.6 & 20.3 & 68. Venezuela & 17.1 & 46.9 & 113. Senegal & 3.9 & 57.7 \\
\hline 24. Greece & 59.4 & 30.1 & 69. Thailand & 16.1 & 60.4 & 114. Chad & 3.5 & 75.3 \\
\hline 25. NZ & 57.7 & 23.3 & 70. Albania & 14.6 & 58.5 & 115. Nepal & 3.4 & 64.7 \\
\hline 26. Israel & 54.7 & 34.4 & 71. Colombia & 14.5 & 48.4 & 116. Bangladesh & 3.3 & 54.8 \\
\hline 27. Malta & 54.3 & 42.5 & 72. Ecuador & 13.7 & 43.0 & 117. Benin & 3.3 & 66.3 \\
\hline 28. Singapore & 53.6 & 47.8 & 73. Jordan & 13.7 & 52.4 & 118. Ghana & 3.3 & 77.6 \\
\hline 29. Qatar & 50.5 & 61.5 & 74. Tunisia & 13.7 & 49.9 & 119. Cote d'Ivoire & 3.1 & 53.4 \\
\hline 30. Slovenia & 50.0 & 31.9 & 75. Peru & 13.6 & 40.0 & 120. S. Leone & 3.1 & 89.5 \\
\hline 31. Portugal & 49.0 & 25.6 & 76. Egypt & 13.5 & 66.3 & 121. M'gascar & 3.0 & 80.2 \\
\hline 32. Brunei & 48.7 & 55.6 & 77. Moldova & 13.0 & 83.6 & 122. Togo & 2.7 & 68.0 \\
\hline 33. Kuwait & 47.0 & 35.8 & 78. Maldives & 12.9 & 101.4 & 123. Burkina Faso & 2.5 & 60.7 \\
\hline 34. Czech Rep & 46.3 & 45.5 & 79. Gabon & 12.7 & 78.4 & 124. Guinea & 2.4 & 80.5 \\
\hline 35. Hungary & 42.6 & 48.1 & 80. Fiji & 12.6 & 57.6 & 125. Mali & 2.3 & 62.4 \\
\hline 36. Bahrain & 41.6 & 45.6 & 81. Georgia & 12.1 & 94.2 & 126. Angola & 2.3 & 64.9 \\
\hline 37. Korea & 40.4 & 41.7 & 82. Botswana & 11.9 & 62.7 & 127. Rwanda & 2.1 & 62.1 \\
\hline 38. Estonia & 39.4 & 47.2 & 83. Namibia & 10.9 & 54.8 & 128. C. Africa & 1.9 & 63.2 \\
\hline 39. Slovakia & 38.8 & 49.5 & 84. Swaziland & 10.8 & 65.4 & 129. M'bique & 1.7 & 61.6 \\
\hline 40. Lithuania & 38.3 & 54.2 & 85. Syria & 10.5 & 57.8 & 130. Niger & 1.3 & 58.5 \\
\hline 41. Poland & 36.7 & 48.8 & 86. Bolivia & 10.2 & 63.6 & 131. G-Bissau & 1.2 & 61.3 \\
\hline 42. Croatia & 36.1 & 50.0 & 87. Equat. Guinea & 10.1 & 71.9 & 132. Congo, D. R. & 0.4 & 61.3 \\
\hline 43. Macao & 36.1 & 44.4 & 88. Paraguay & 9.9 & 50.4 & Mean--All & 27.4 & 52.9 \\
\hline 44. Latvia & 33.4 & 54.9 & 89. Cape Verde & 8.8 & 47.6 & --Rich & 67.9 & 30.3 \\
\hline 45. Lebanon & 32.0 & 56.0 & 90. Bhutan & 8.0 & 66.3 & --Poor & 15.5 & 60.7 \\
\hline
\end{tabular}

Notes: 1. Standard deviations (SD) are to be divided by 100.

2. "Poor" countries are those with those numbered 29 and 32-132, excluding 34, 37 and 39, while the remainder are "rich". Poor countries coincide with "Emerging and Developing Economies" of the IMF's 2010 World Economic Outlook; see http://www.imf.org/external/pubs/ft/weo/2010/01/weodata/groups.htm\#oem. 
TABLE 2

RELATIVE PRICES AND INCOMES, 132 COUNTRIES IN 2005

$$
\mathrm{w}_{\text {ic }} \log \left(\mathrm{p}_{\text {ic }} / \mathrm{P}_{\mathrm{c}}\right)=\alpha_{\mathrm{i}}+\gamma_{\mathrm{i}} \mathrm{D}_{\mathrm{c}}+\beta_{\mathrm{i}} \log \left(\mathrm{Q}_{\mathrm{c}} / \overline{\mathrm{Q}}\right)+\varepsilon_{\text {ic }}
$$

\begin{tabular}{lcccccc}
\hline \hline Commodity & $\begin{array}{c}\text { Intercept } \\
\left.\alpha_{\mathrm{i}} \times 100\right)\end{array}$ & $\begin{array}{c}\text { Poor country } \\
\text { dummy } \\
\gamma_{\mathrm{i}}(\times 100)\end{array}$ & $\begin{array}{c}\text { Income } \\
\beta_{\mathrm{i}}(\times 100)\end{array}$ & $\begin{array}{c}\text { Income } \\
\text { elasticity } \\
\beta_{\mathrm{i}} / \mathrm{w}_{\mathrm{i}}\end{array}$ & $\begin{array}{c}\text { SEE } \\
\mathrm{R}^{2}\end{array}$ & $\begin{array}{c}\text { SE } \\
(\times 100)\end{array}$ \\
\hline Food & $9.71(0.99)$ & $0.22(1.21)$ & $-5.31(0.44)$ & -0.19 & 0.68 & 4.34 \\
Alcoholic beverages & $0.08(0.21)$ & $-0.11(0.26)$ & $0.11(0.10)$ & 0.03 & 0.03 & 0.94 \\
Clothing & $-0.55(0.44)$ & $2.71(0.54)$ & $0.88(0.20)$ & 0.17 & 0.18 & 1.93 \\
Housing & $-5.34(1.40)$ & $2.38(1.71)$ & $2.70(0.62)$ & 0.18 & 0.15 & 6.15 \\
Furnishings & $-0.09(0.26)$ & $0.91(0.32)$ & $0.49(0.12)$ & 0.10 & 0.12 & 1.15 \\
Health & $-4.53(0.67)$ & $-2.41(0.82)$ & $-0.24(0.30)$ & -0.03 & 0.08 & 2.94 \\
Transport & $3.84(0.63)$ & $0.12(0.77)$ & $0.19(0.28)$ & 0.02 & 0.00 & 2.76 \\
Communication & $-0.14(0.24)$ & $0.84(0.29)$ & $-0.03(0.11)$ & -0.01 & 0.12 & 1.05 \\
Recreation & $0.39(0.17)$ & $0.50(0.20)$ & $0.17(0.07)$ & 0.03 & 0.05 & 0.74 \\
Education & $-4.39(0.87)$ & $-5.23(1.06)$ & $0.28(0.39)$ & 0.03 & 0.30 & 3.83 \\
Restaurants & $1.48(0.27)$ & $0.09(0.32)$ & $0.47(0.12)$ & 0.11 & 0.17 & 1.17 \\
Miscellaneous & $-0.47(0.21)$ & $-0.02(0.26)$ & $0.29(0.09)$ & 0.04 & 0.13 & 0.93 \\
\hline
\end{tabular}

Notes: 1. Standard errors in parentheses.

2. Regressions exclude US, the base country.

3. Elasticities in the third last column are evaluated at means. 
TABLE 3

INCOME ELASTICITIES OF

PRICES AND DEMAND

\begin{tabular}{|c|c|c|c|c|c|}
\hline \multirow[b]{3}{*}{$\begin{array}{l}\text { Commodity } \\
\text { (1) }\end{array}$} & \multirow{3}{*}{$\begin{array}{c}\text { Income } \\
\text { elasticity } \\
\text { of price } \\
\beta_{\mathrm{i}} / \mathrm{w}_{\mathrm{i}} \\
(2)\end{array}$} & \multicolumn{4}{|c|}{ Income elasticity of demand } \\
\hline & & \multicolumn{3}{|c|}{ Value of excess supply elasticity $\Delta$} & \multirow{2}{*}{$\begin{array}{c}\text { Directly } \\
\text { estimated } \\
(6)\end{array}$} \\
\hline & & $\begin{array}{c}1 \\
(3)\end{array}$ & $\begin{array}{c}2 \\
(4) \\
\end{array}$ & $\begin{array}{c}3 \\
(5) \\
\end{array}$ & \\
\hline Food & -0.19 & 0.81 & 0.62 & 0.43 & 0.66 \\
\hline Alcohol & 0.03 & 1.00 & 0.06 & 1.09 & 0.93 \\
\hline Clothing & 0.17 & 0.17 & 1.34 & 1.51 & 0.96 \\
\hline Housing & 0.18 & 1.18 & 1.36 & 1.54 & 1.04 \\
\hline Furnishings & 0.10 & 1.10 & 1.20 & 1.30 & 1.07 \\
\hline Health & -0.03 & 0.97 & 0.94 & 0.91 & 1.16 \\
\hline Transport & 0.02 & 1.02 & 1.04 & 1.06 & 1.18 \\
\hline Communication & -0.01 & 0.99 & 0.98 & 0.97 & 1.22 \\
\hline Recreation & 0.03 & 1.03 & 1.06 & 1.09 & 1.36 \\
\hline Education & 0.03 & 1.03 & 1.06 & 1.09 & 0.99 \\
\hline Restaurants & 0.11 & 1.11 & 1.22 & 1.33 & 1.28 \\
\hline Miscellaneous & 0.04 & 1.04 & 1.08 & 1.12 & 1.30 \\
\hline
\end{tabular}

Sources: Column 2 is from Table 2; column 6 is derived from Clements and Chen (2010).

TABLE 4

IMPLIED PRICE DISPERSION AND INCOME

$$
\mathrm{y}_{\mathrm{c}}=\lambda_{0}+\lambda_{1} \mathrm{x}_{\mathrm{c}}+\lambda_{2} \mathrm{x}_{\mathrm{c}}^{2}
$$

\begin{tabular}{|c|c|c|c|c|c|c|c|c|}
\hline \multirow[b]{2}{*}{$\begin{array}{l}\text { Country } \\
\text { group }\end{array}$} & \multicolumn{3}{|c|}{ Order of quadratic coefficients } & \multicolumn{2}{|c|}{ Minimum variance } & \multicolumn{3}{|c|}{ Country nearest MV income } \\
\hline & $\begin{array}{c}\text { Second } \\
\lambda_{2}\end{array}$ & $\begin{array}{c}\text { First } \\
\lambda_{1}\end{array}$ & $\begin{array}{c}\text { Zero } \\
\lambda_{0}\end{array}$ & $\begin{array}{c}\text { Income } \\
x^{*}=-\lambda_{1} / 2 \lambda_{2}\end{array}$ & $\begin{array}{c}\text { Variance } \\
\mathrm{y}_{\mathrm{x}^{*}}\end{array}$ & Country & Income & Variance \\
\hline$(1)$ & (2) & $(3)$ & $(4)$ & (5) & (6) & (7) & (8) & $(9)$ \\
\hline Poor & $\begin{array}{c}2.47 \\
(0.43)\end{array}$ & $\begin{array}{l}-6.55 \\
(2.60)\end{array}$ & $\begin{array}{l}33.36 \\
(1.24)\end{array}$ & $\begin{array}{l}132.71 \\
(54.23)\end{array}$ & $\begin{array}{l}29.01 \\
(1.68)\end{array}$ & 24.Greece & 133.19 & 9.08 \\
\hline Rich & $\begin{array}{c}3.38 \\
(0.49)\end{array}$ & $\begin{array}{l}-11.23 \\
(1.85)\end{array}$ & $\begin{array}{l}26.41 \\
(2.36)\end{array}$ & $\begin{array}{l}166.28 \\
(14.70)\end{array}$ & $\begin{array}{l}17.07 \\
(0.98)\end{array}$ & 3.Iceland & 163.85 & 8.44 \\
\hline Difference & $\begin{array}{l}-0.91 \\
(0.16)\end{array}$ & $\begin{array}{c}4.68 \\
(0.98)\end{array}$ & $\begin{array}{c}6.95 \\
(2.13)\end{array}$ & $\begin{array}{l}-33.57 \\
(14.25)\end{array}$ & $\begin{array}{c}11.94 \\
(1.41)\end{array}$ & & & \\
\hline
\end{tabular}

Notes: 1. Asymptotic standard errors in parenthesis.

2. "Country nearest minimum variance" is restricted to those of the corresponding category (rich/poor).

3. Budget shares of Chile and France are used to represent the rich and poor country groups, respectively. These are listed in column 2 of Table 5.

4. All entries are to be divided by 100 . 
TABLE 5

\section{COMMODITY DECOMPOSITION OF}

MINIMUM VARIANCE INCOME

\begin{tabular}{|c|c|c|c|c|c|c|c|}
\hline $\begin{array}{l}\text { Commodity } \\
\text { (1) }\end{array}$ & $\begin{array}{c}\text { Budget } \\
\text { share } \\
\mathrm{w}_{\mathrm{i}} \\
(\times 100) \\
(2)\end{array}$ & \multicolumn{2}{|c|}{$\begin{array}{l}\text { Weight in eq (15) } \\
\qquad \begin{array}{c}\kappa_{\mathrm{i}}=\frac{\beta_{\mathrm{i}}^{2} / \mathrm{w}_{\mathrm{i}}}{\sum_{\mathrm{i}=1}^{12} \beta_{\mathrm{i}}^{2} / \mathrm{w}_{\mathrm{i}}} \\
(\times 100) \\
(3)\end{array}\end{array}$} & \multicolumn{2}{|c|}{$\begin{array}{c}\text { Ratio of intercept } \\
\text { to slope } \\
-\frac{\tilde{\alpha}_{\mathrm{i}}}{\beta_{\mathrm{i}}} \\
(4)\end{array}$} & \multicolumn{2}{|c|}{$\begin{array}{l}\text { Contribution to } \\
\text { MV income } \\
-\kappa_{\mathrm{i}} \cdot \frac{\tilde{\alpha}_{\mathrm{i}}}{\beta_{\mathrm{i}}}(\times 100) \\
\text { (5) }\end{array}$} \\
\hline \multicolumn{8}{|c|}{ A. Poor } \\
\hline 1. Food & 16.22 & 70.44 & $(12.13)$ & 1.87 & $(0.21)$ & 131.73 & $(21.03)$ \\
\hline 2. Alcohol & 2.65 & 0.19 & $(0.32)$ & 0.27 & $(1.28)$ & 0.05 & $(0.19)$ \\
\hline 3. Clothing & 7.09 & 4.43 & $(1.95)$ & -2.45 & $(0.49)$ & -10.86 & $(3.22)$ \\
\hline 4. Housing & 15.37 & 19.22 & $(6.38)$ & 1.10 & $(0.43)$ & 21.07 & $(4.86)$ \\
\hline 5. Furnishings & 7.32 & 1.33 & $(0.65)$ & -1.67 & $(0.37)$ & -2.22 & $(0.81)$ \\
\hline 6. Health & 10.57 & 0.22 & $(0.54)$ & -28.92 & $(34.81)$ & -6.39 & $(7.93)$ \\
\hline 7. Transport & 13.59 & 0.11 & $(0.31)$ & -20.84 & $(30.06)$ & -2.24 & $(3.39)$ \\
\hline 8. Communication & 2.91 & 0.01 & $(0.08)$ & 23.33 & (99.84) & 0.29 & $(1.22)$ \\
\hline 9. Recreation & 4.03 & 0.29 & $(0.26)$ & -5.24 & $(2.18)$ & -1.52 & $(0.79)$ \\
\hline 10. Education & 9.00 & 0.35 & $(0.97)$ & 34.36 & $(48.64)$ & 12.13 & $(16.67)$ \\
\hline 11. Restaurants & 2.98 & 3.00 & $(1.55)$ & -3.34 & $(0.77)$ & -10.03 & $(3.28)$ \\
\hline 12. Miscellaneous & 8.26 & 0.41 & $(0.27)$ & 1.69 & $(0.76)$ & 0.70 & $(0.24)$ \\
\hline 13. Total & 100.00 & 100.00 & & & & 132.71 & $(54.23)$ \\
\hline \multicolumn{8}{|c|}{ B. $\underline{\text { Rich }}$} \\
\hline 14. Food & 10.58 & 78.93 & $(5.77)$ & 1.83 & $(0.15)$ & 144.33 & $(14.88)$ \\
\hline 15. Alcohol & 2.37 & 0.15 & $(0.27)$ & -0.73 & $(2.32)$ & -0.11 & $(0.25)$ \\
\hline 16. Clothing & 3.71 & 6.18 & $(2.74)$ & 0.63 & $(0.42)$ & 3.86 & (3.65) \\
\hline 17. Housing & 19.72 & 10.95 & (4.64) & 1.98 & $(0.42)$ & 21.65 & $(8.99)$ \\
\hline 18. Furnishings & 4.58 & 1.55 & $(0.75)$ & 0.18 & $(0.51)$ & 0.29 & $(0.87)$ \\
\hline 19. Health & 12.04 & 0.14 & $(0.35)$ & -18.88 & $(24.92)$ & -2.67 & $(3.05)$ \\
\hline 20. Transport & 11.35 & 0.09 & $(0.27)$ & -20.21 & $(31.92)$ & -1.90 & (2.63) \\
\hline 21. Communication & 2.15 & 0.01 & $(0.07)$ & -4.67 & $(25.43)$ & -0.06 & $(0.20)$ \\
\hline 22. Recreation & 8.83 & 0.10 & $(0.09)$ & -2.29 & $(1.81)$ & -0.22 & $(0.10)$ \\
\hline 23. Education & 7.11 & 0.33 & $(0.91)$ & 15.68 & $(20.10)$ & 5.12 & $(7.83)$ \\
\hline 24. Restaurants & 4.77 & 1.37 & $(0.72)$ & -3.15 & $(1.23)$ & -4.32 & $(1.05)$ \\
\hline 25. Miscellaneous & 12.80 & 0.19 & $(0.13)$ & 1.62 & $(0.56)$ & 0.32 & $(0.22)$ \\
\hline 26. Total & 100.00 & 100.00 & & & & 166.28 & $(14.70)$ \\
\hline
\end{tabular}

Note: Asymptotic standard errors in parenthesis. 
TABLE 6

DISPERSION-EQUIVALENT INCOME,

ILLUSTRATIVE CALCULATIONS

\begin{tabular}{ccccc}
\hline \hline \multicolumn{2}{c}{$\begin{array}{c}\text { Income } \\
\text { (Relative to mean) }\end{array}$} & & \multicolumn{2}{c}{$\begin{array}{c}\text { Dispersion equivalent income } \\
\text { (Additional income relative to } \\
\text { the base income of the poor) }\end{array}$} \\
\cline { 1 - 2 } \cline { 5 - 5 } $\begin{array}{c}\text { Logarithmic }(\times 100) \\
(1)\end{array}$ & $\begin{array}{c}\text { Percentage } \\
(2)\end{array}$ & & $\begin{array}{c}\text { Logarithmic }(\times 100) \\
(3)\end{array}$ & $\begin{array}{c}\text { Percentage } \\
(4)\end{array}$ \\
\hline-111 & 33 & 3 & 3 \\
-76 & 47 & 28 & 33 \\
-57 & 56 & 47 & 61 \\
-26 & 77 & 113 & 208 \\
\hline
\end{tabular}


FIGURE 1

RELATIVE PRICES

IN RICH AND POOR COUNTRIES

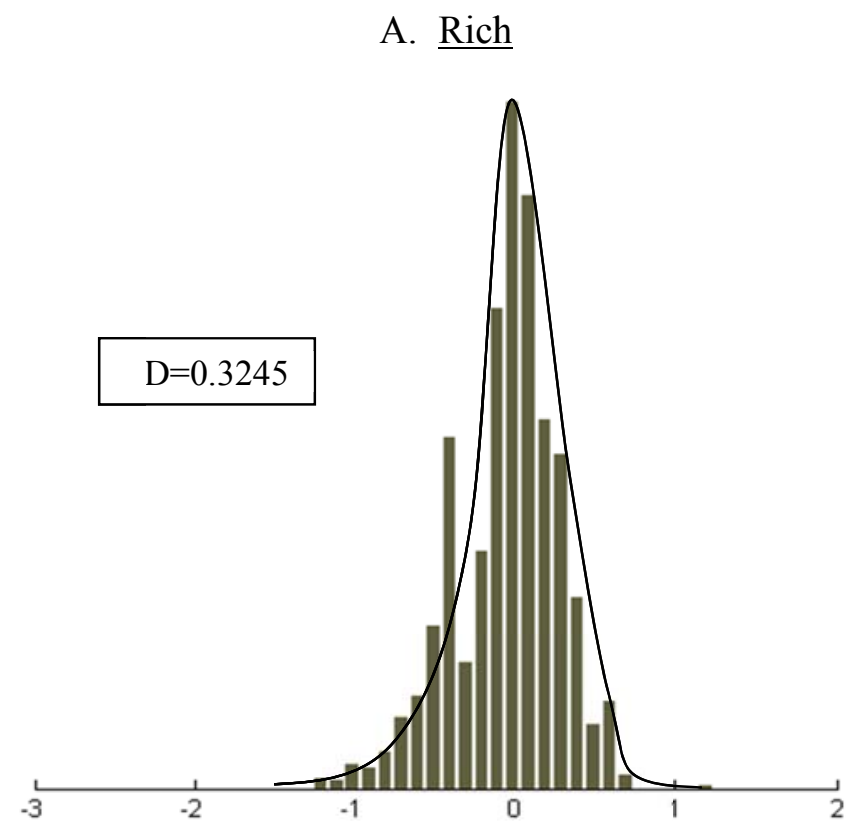

B. $\underline{\text { Poor }}$

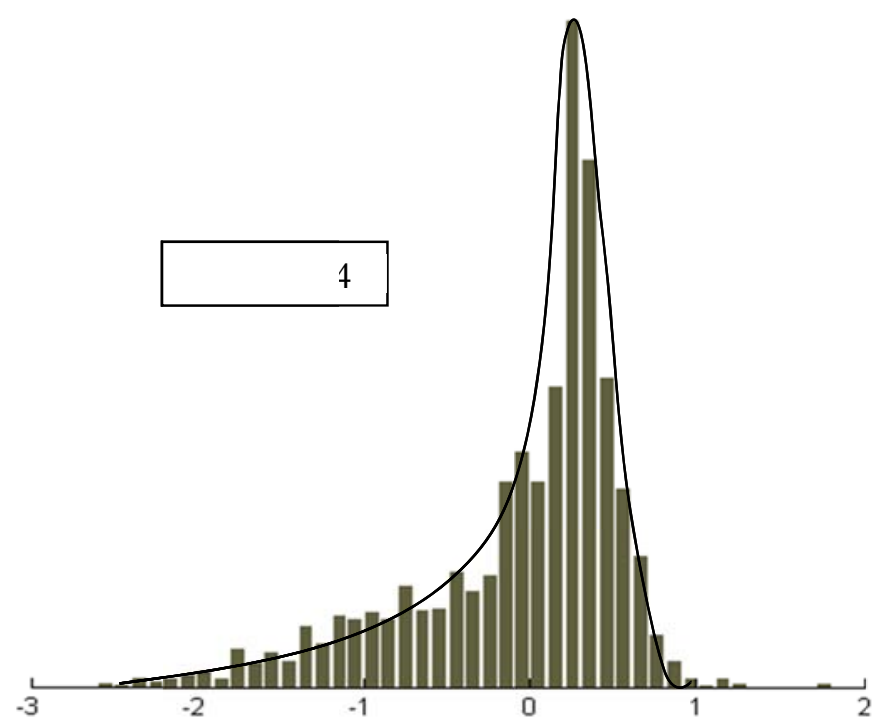


FIGURE 2

RELATIVE PRICES AND INCOMES,

132 COUNTRIES IN 2005

1. Food

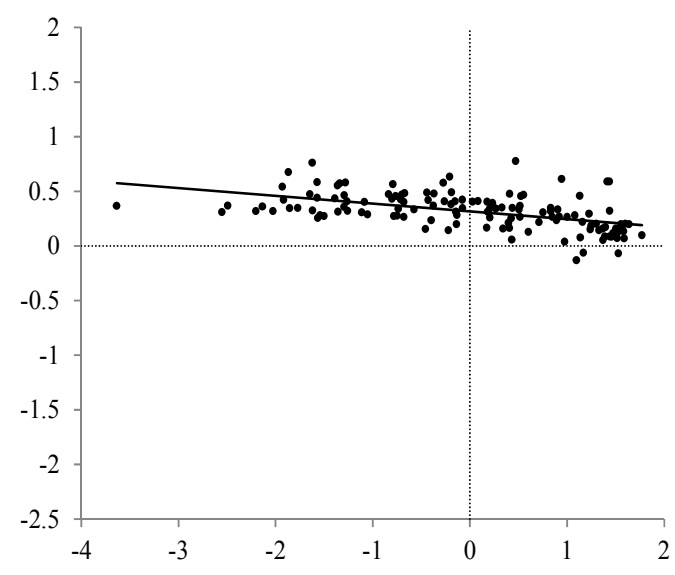

3. Clothing

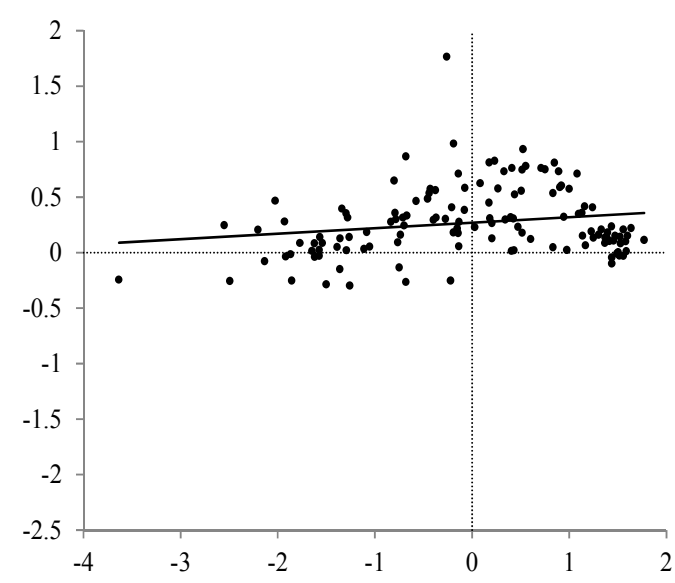

5. Furnishings

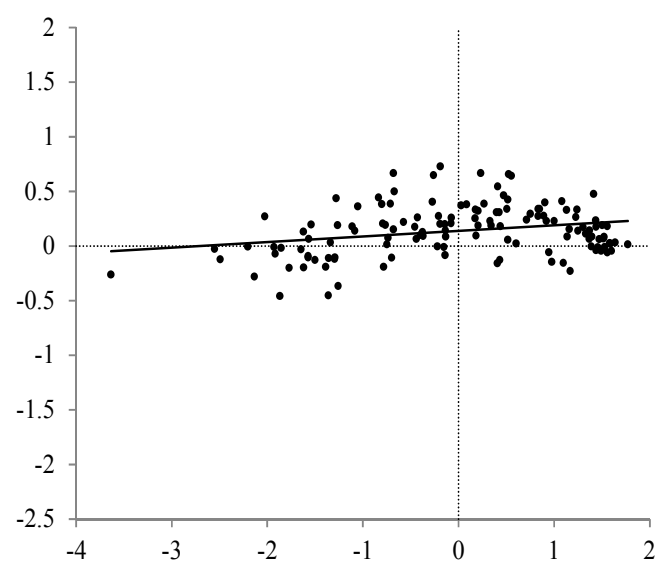

2. Alcoholic Beverages

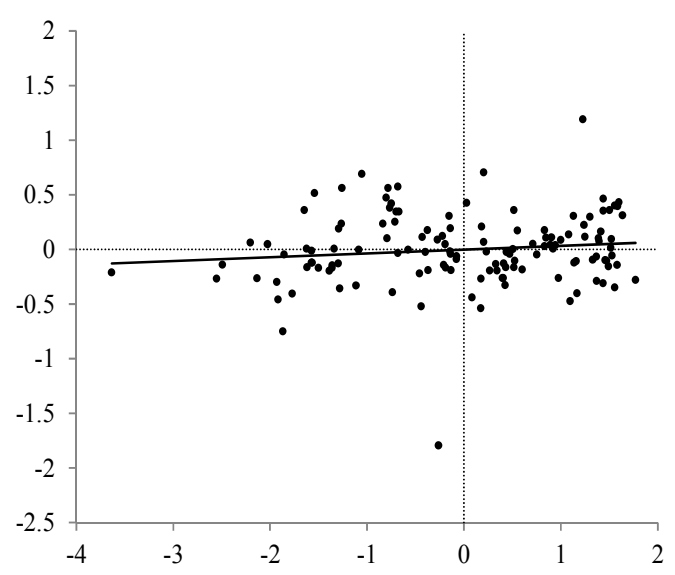

4. Housing

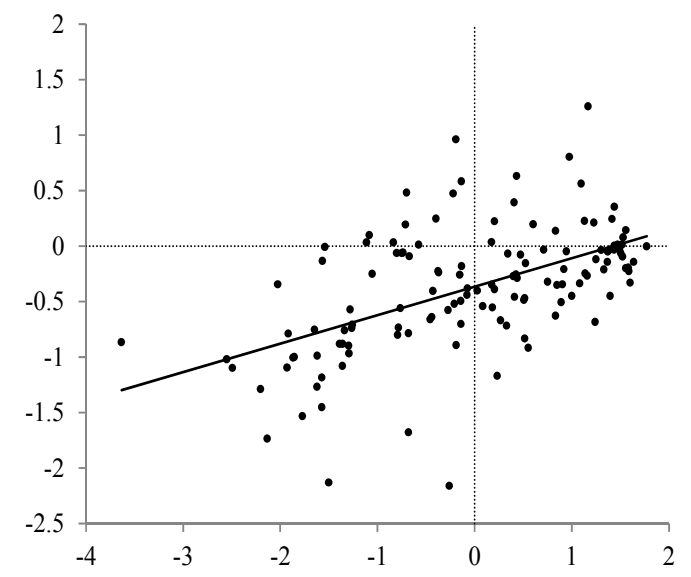

6. Health

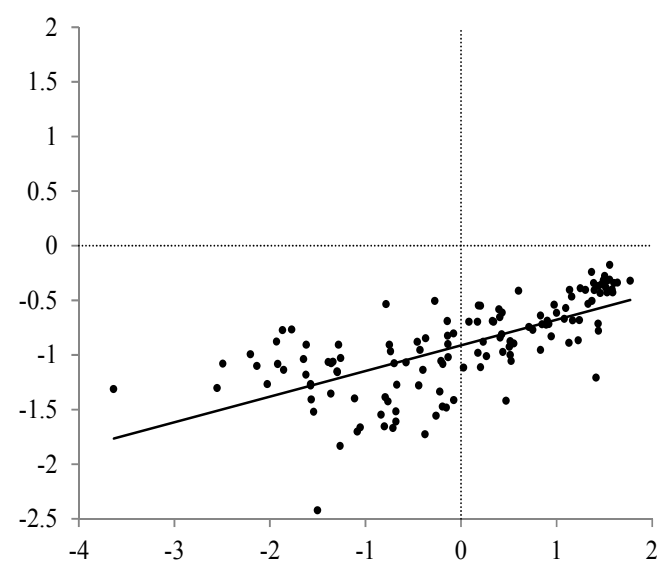

(Continued on next page) 
FIGURE 2 (continued)

\section{RELATIVE PRICES AND INCOMES,}

\section{COUNTRIES IN 2005}

\section{Transport}

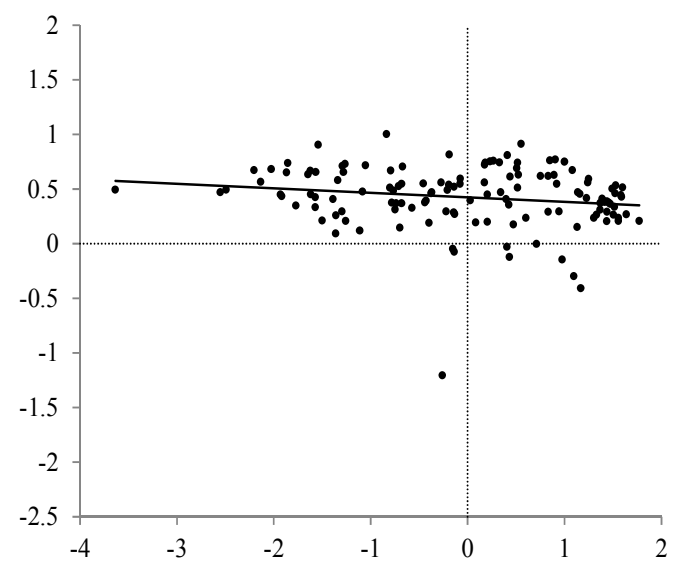

9. Recreation

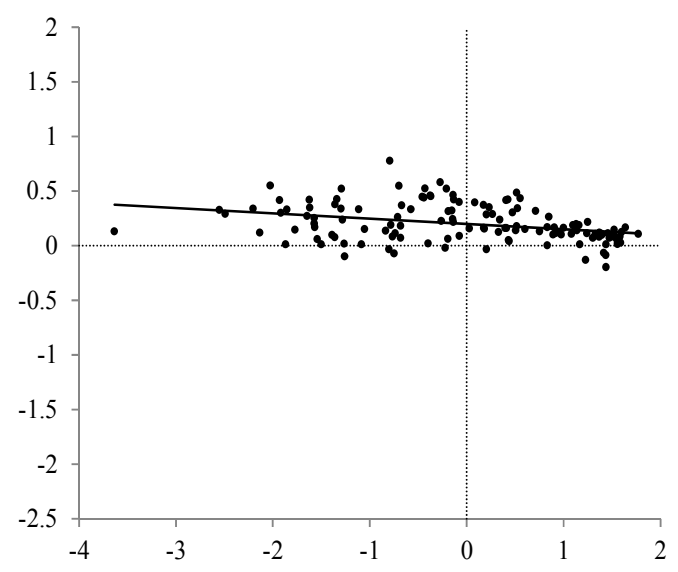

11. Restaurants

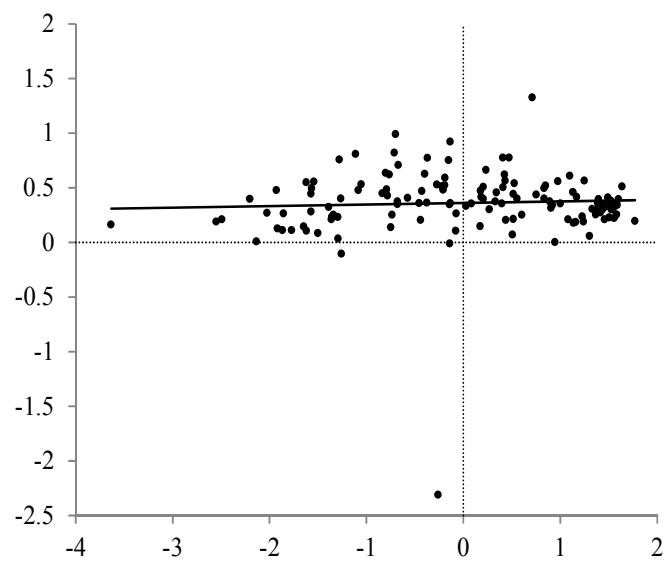

8. Communication

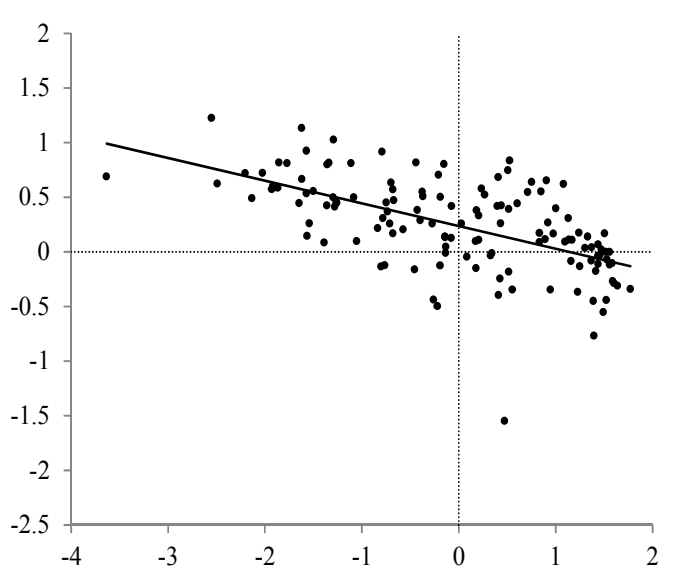

10. Education

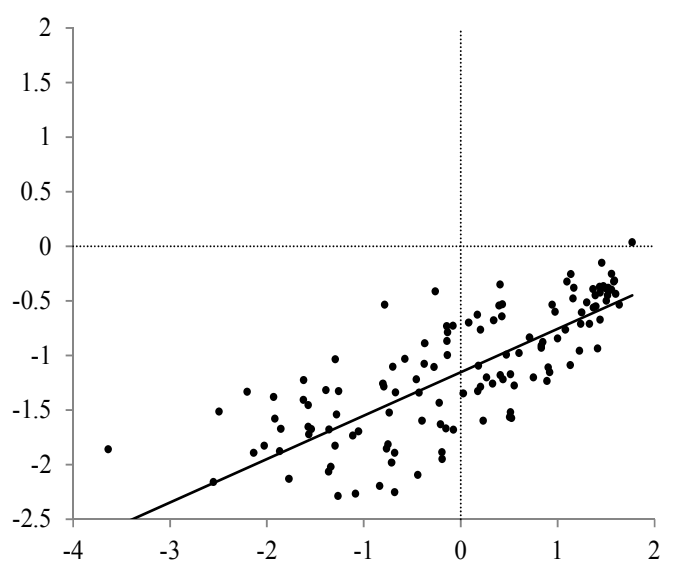

12. Miscellaneous

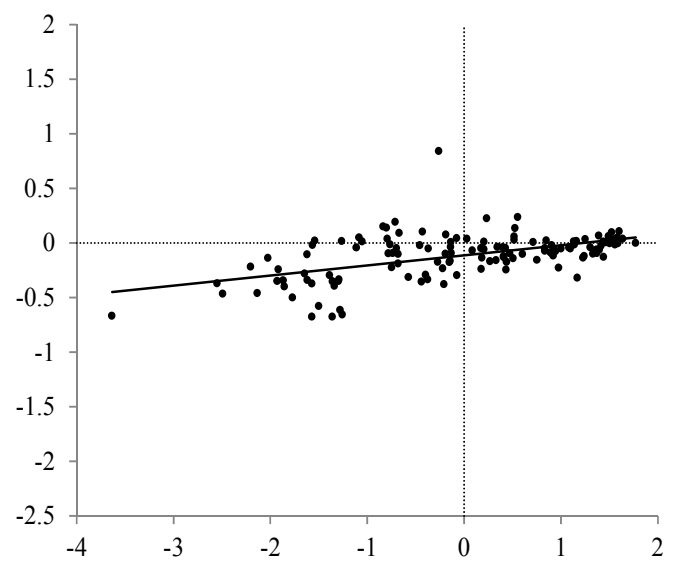

Notes: 1 . In panel $\mathrm{i}(\mathrm{i}=1, \ldots, 12)$, the $\mathrm{i}^{\text {th }}$ relative price, $\left(\log \mathrm{p}_{\mathrm{ic}}-\log \mathrm{P}_{\mathrm{c}}\right) \times 100$, is plotted against relative income per-capita, $\log \left(\mathrm{Q}_{\mathrm{c}} / \overline{\mathrm{Q}}\right) \times 100, \mathrm{c}=1, \ldots, 132$, where $\overline{\mathrm{Q}}$ is geometric mean income. The solid line is the LS regression line.

2. As it is an outlier, country number 114, Chad, is excluded from "Education" plot, but is included in the regression line. 3. US, the base country, is excluded from all scatterplots. 
FIGURE 3

\section{PRICE DISPERSION AND INCOME}

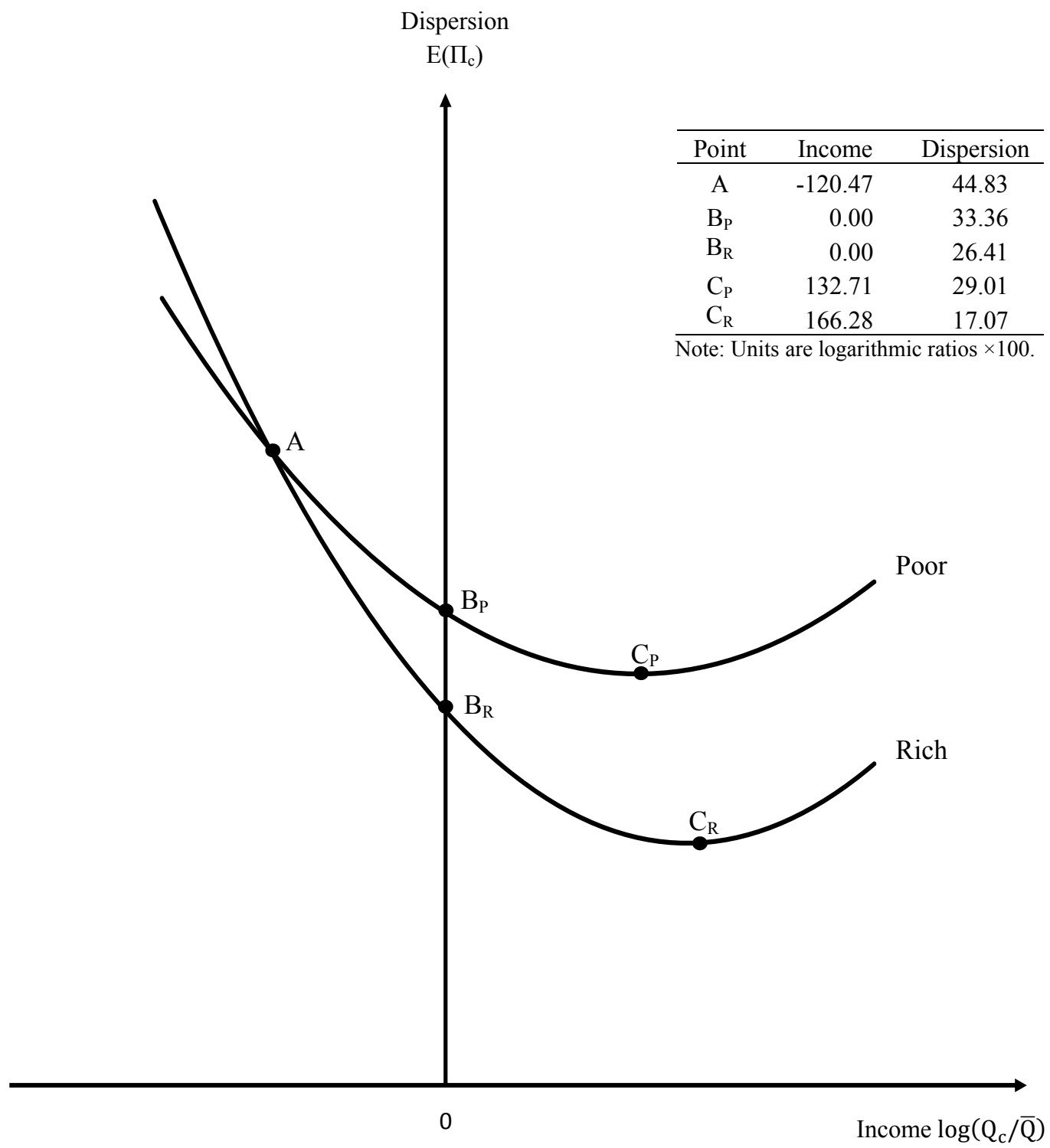


FIGURE 4

PRICE DISPERSION AND INCOME

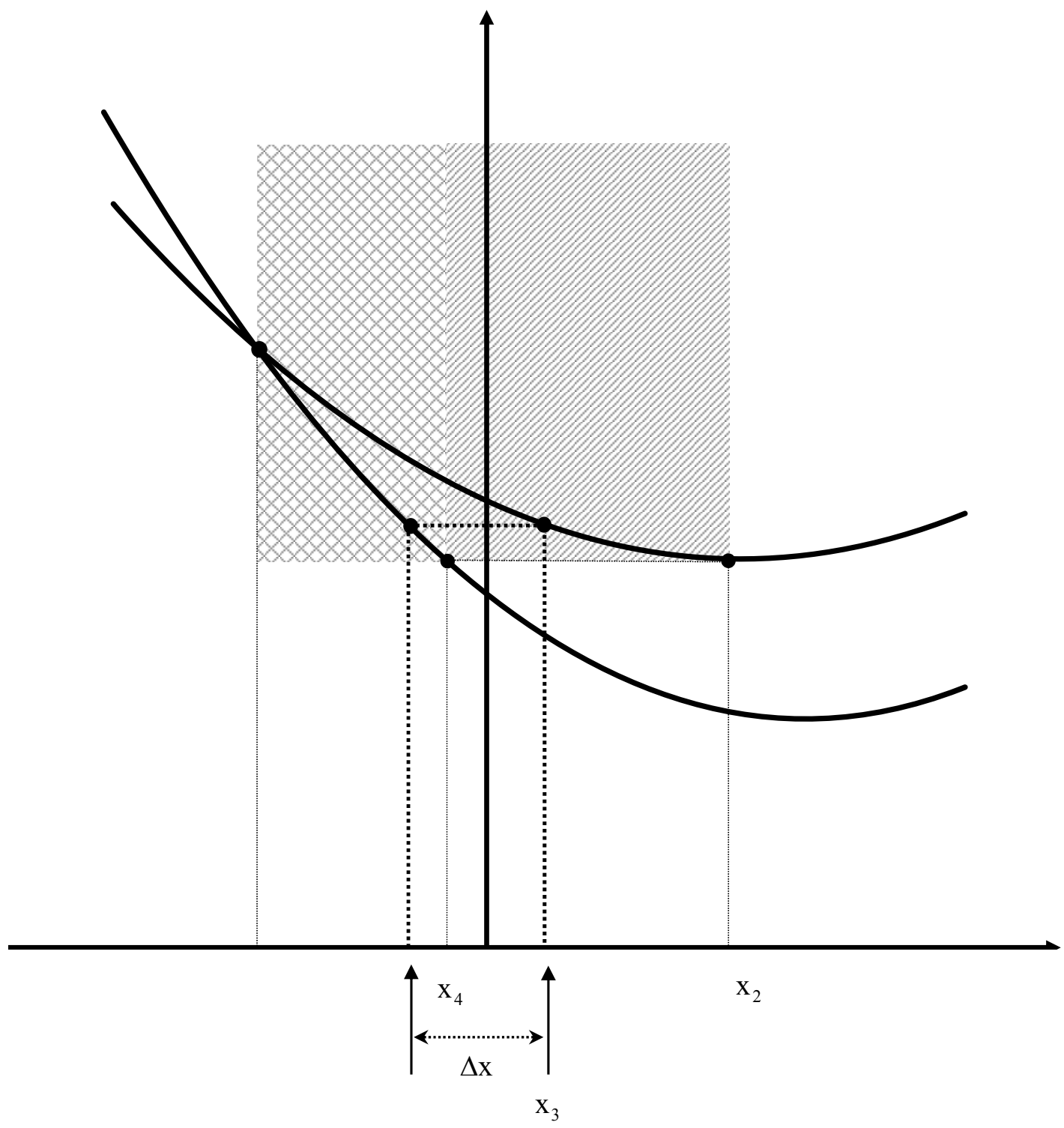


FIGURE 5

DEI AND INCOME

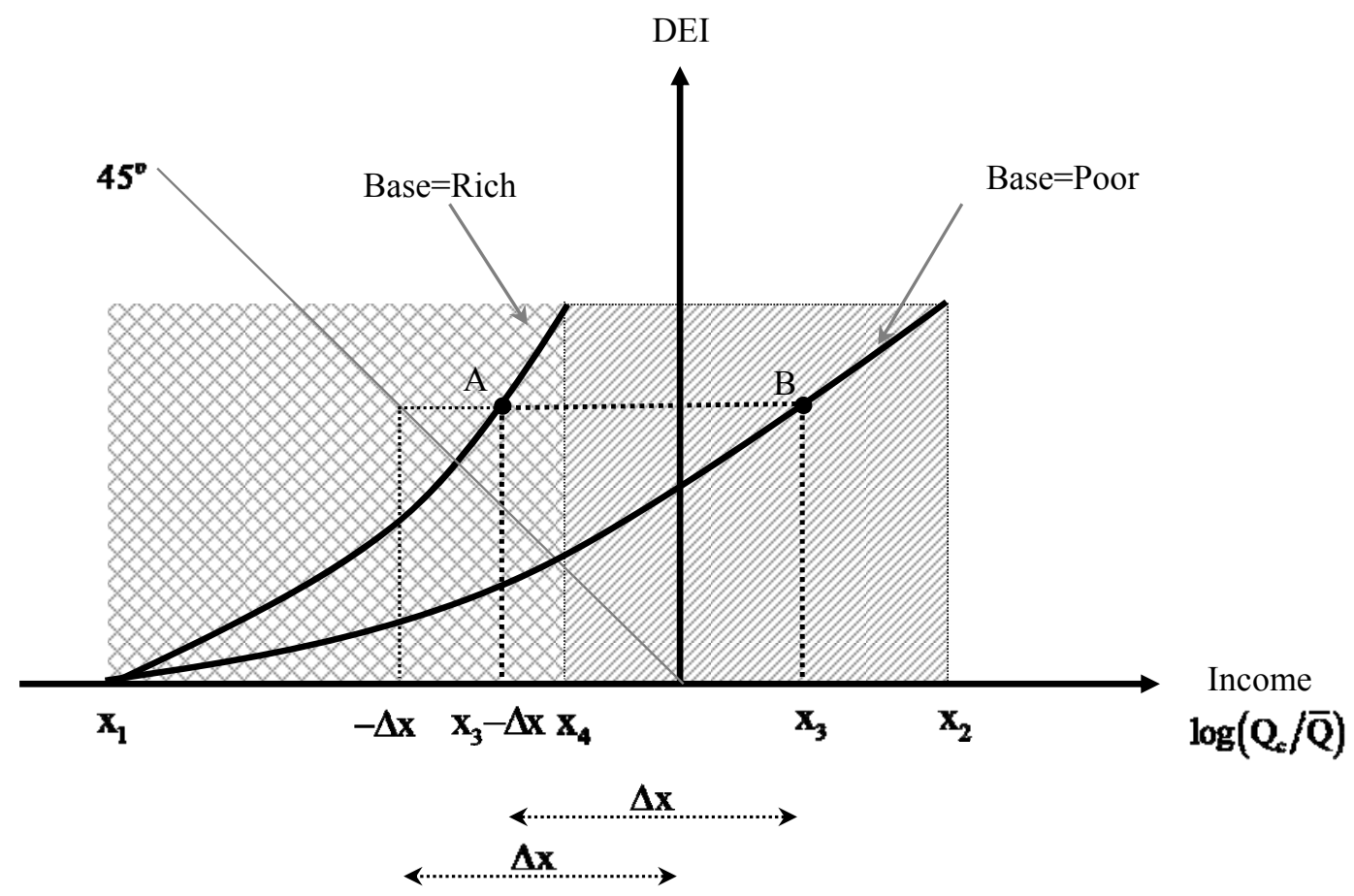




\section{Appendix A1}

\section{THE DATA AND FURTHER RESULTS}

\section{The Data}

The data used are budget shares, relative prices and real income per capita. Tables A1 and A2 contain the budget and shares prices, while Table 1 contains income. These data come from the World Bank’s International Comparisons Program (2008).

\section{Possible Outliers}

The ICP prices data contain some outliers for Lebanon (country number 45), Iran (52) and Georgia (81). Lebanon has a high relative price for restaurants, while this price is low in Georgia; these two observations stand out in panel 11 of Figure 2. Additionally, in Georgia prices are low for alcoholic beverages, housing and transport, and high for clothing, furnishings and miscellaneous. Finally, in Iran prices seem to be (marginally) high for food and substantially low for communication. In view of the sample size, these outliers are unlikely to have any material impact on the results. Nevertheless, as a robustness check we redo the results of Table 4 with the data for the three countries omitted. As can be seen from panel B of Table A3, this has only a very marginal impact on the results.

\section{More on Rich vs Poor}

In Table 2 poor countries were distinguished from the rich by means of a shift in the intercept for each commodity, while the slope was taken to be the same. We examine this treatment in Figure A1, which extends Figure 2 by allowing both the slope and intercept to vary across country groups. For most commodities, the scatterplot shows something approximating an intercept shift. There are some exceptions to this general rule: for clothing and furnishings, the slopes of the regression lines appear different for the two country groups. Although they do not change signs, the slopes for health, communication and education also seem to differ across country groups. Clothing and furnishing, the two commodities that appear to depart most from the common slope assumption, each absorb a little over 5 percent of the budget for an average country. As they are only modest-sized components of the overall budget, even these cases may not substantially affect the results.

Next, we redo the results of Table 2 by allowing both the intercepts and slopes to vary, which amounts to estimating separate equations for the rich and poor. Panel A of Table A4 reproduces the previous results where both groups of countries are combined. As can be seen from panel B of the table, the intercepts on the poor generally approximate the sum of the intercept and poor country dummy shown in panel A, as is to be expected. Similarly, the slopes are not substantially different between panels $\mathrm{A}$ and $\mathrm{B}$, with all signs being the same. Panel $\mathrm{C}$ of the table gives the results for the 
rich countries and there are some differences here. Table A5 reveals that there are significant differences of the slopes in the two groups for clothing, furnishings, health and education, and a joint test of the hypothesis that the 12 slopes are pairwise equal is rejected. However, the differences are not too large for the important commodity food.

We return to Table A4 to consider further the differences between the poor and rich country groups. It follows from equation (10) that the income elasticity of the relative price of good $\mathrm{i}$ is

$$
\frac{\beta_{\mathrm{i}}}{\mathrm{w}_{\mathrm{i}}}=\frac{1}{\Delta}\left(\theta_{\mathrm{i}}-1\right)
$$

where $\Delta>0$ is the excess supply elasticity (for simplicity, this is taken to be the same for all goods), and $\theta_{i}$ is the conventional income elasticity of demand. This shows that $\beta_{i} / w_{i}$ is proportional to the difference between $\theta_{\mathrm{i}}$ and the weighted mean over all goods of these elasticities, viz., unity. Accordingly, for necessities $\left(\theta_{i}<1\right)$, the price elasticity $\beta_{i} / w_{i}$ is negative. From panel $B$ of Table A4, the income elasticity of the relative price of food in the poor is estimated to be -0.16 , while it is 0.53 in the rich (panel C). Food is a necessity in both groups, as is to be expected, but it is more of a necessity, or less of a luxury, for the rich. One can readily appreciate that this is reasonable by considering the implausibility of the alternative whereby food is more of a luxury as income rises. The qualification to the discussion is that the estimated income coefficient for food for the rich has a relatively high standard error (it is more than three times larger than that for the poor). More will be said about this issue in the next paragraph. Another pattern in the results is that in 11 out of 12 cases, the income coefficients for the rich are larger in absolute value than those for the poor. This is reflected in the greater dispersion of the income elasticities $\beta_{i} / w_{i}$ for the rich, which implies a larger dispersion of the income elasticities of demand. As discussed in Section 6, this agrees with the idea that relative to the poor, the consumption basket of the rich is more diversified and less specialised in food in particular.

As stated above, the results for the poor (contained in panel B of Table A4) are quite similar to those for all countries combined (panel A); but the rich (panel C) differ substantially from all countries. One reason for this asymmetry is that 99 countries belong to the poor group, while the rich comprises only 32 , so the weight for the poor in the "world" is about three times that of the rich. As the world is a weighted average of the two groups, the results of panel A are skewed towards the poor. This is also the reason why the standard errors of the estimated coefficients for the rich are all substantially larger than those for the poor. Thus, while a case could be made that the two groups should be kept separate, the problem is that the relatively small sample size for the rich group leads to imprecise estimates for this group. In short, there is a tradeoff between more detailed modelling of individual responses and the precision of estimates. 
Panel A of Table A6 gives the implied quadratic coefficients when all countries are combined; this is reproduced from Table 4. Again, the quadratic coefficients for the poor (panel B) are not substantially different from the combined case (panel A). For the rich, the coefficients change, but not their signs. The zero-order coefficient $\lambda_{0}$ for the rich is now larger than that for the poor, while the relative sizes of $\lambda_{1}$ and $\lambda_{2}$ for the two groups remain unchanged. Figure A2 contains the corresponding plots and as can be seen, when the two groups are separated the curve for the rich has substantially more curvature and there are now two intersection points within the relevant range. While the curve for the rich seems to change appreciably when the two groups are separated, it needs to be kept in mind that there is now substantially more sampling variability underlying that curve due to the smaller number of observations for the rich, as discussed above.

\section{$\underline{\text { A Weighted Scatter }}$}

Figure A3 repeats the scatterplots of Figure 2 but with each relative price weighted by its budget share to reflect its relative importance. These scatters, which correspond to the regressions of Table 2, are not appreciably different to their unweighted counterparts.

\section{Appendix A2}

\section{THE WELFARE COST OF PRICE DISPERSION}

This appendix derives the expression for the welfare cost, equation (18), that is implied by Selvanathan's (1985) model. To place that model in context, we start with general differential demand equations.

\section{Demand Equations}

Let $p_{i}, q_{i}$ be the price and quantity consumed of $\operatorname{good} i(i=1, \ldots, n)$, so that $M=\sum_{i=1}^{n} p_{i} q_{i}$ is total expenditure ("income" for short) and $\mathrm{w}_{\mathrm{i}}=\mathrm{p}_{\mathrm{i}} \mathrm{q}_{\mathrm{i}} / \mathrm{M}$ is the budget share of $\mathrm{i}$. A Marshallian

demand equation for good $\mathrm{i}$ is $\mathrm{q}_{\mathrm{i}}=\mathrm{q}_{\mathrm{i}}\left(\mathrm{M}, \mathrm{p}_{1}, \ldots, \mathrm{p}_{\mathrm{n}}\right)$, which can be written in differential form as $\mathrm{dq}_{\mathrm{i}}=\left(\partial \mathrm{q}_{\mathrm{i}} / \partial \mathrm{M}\right) \mathrm{dM}+\sum_{\mathrm{j}=1}^{\mathrm{n}}\left(\partial \mathrm{q}_{\mathrm{i}} / \partial \mathrm{p}_{\mathrm{j}}\right) \mathrm{d} \mathrm{p}_{\mathrm{j}}$. Defining $\mathrm{s}_{\mathrm{ij}}$ as the compensated price slope of the demand equation and using the Slutsky decomposition $\partial \mathrm{q}_{\mathrm{i}} / \partial \mathrm{p}_{\mathrm{j}}=\mathrm{s}_{\mathrm{ij}}-\mathrm{q}_{\mathrm{j}}\left(\partial \mathrm{q}_{\mathrm{i}} / \partial \mathrm{M}\right)$, we have

$$
\mathrm{dq}_{\mathrm{i}}=\frac{\partial \mathrm{q}_{\mathrm{i}}}{\partial \mathrm{M}}\left(\mathrm{dM}-\sum_{\mathrm{j}} \mathrm{q}_{\mathrm{j}} \mathrm{dp}_{\mathrm{j}}\right)+\sum_{\mathrm{j}=1}^{\mathrm{n}} \mathrm{s}_{\mathrm{ij}} \mathrm{dp} \mathrm{p}_{\mathrm{j}}
$$


Multiplying both sides of the above equation by $\mathrm{p}_{\mathrm{i}} / \mathrm{M}$ and using the identity $\mathrm{dx} / \mathrm{x}=\mathrm{d}(\log \mathrm{x})$, we obtain

$$
\mathrm{w}_{\mathrm{i}} \mathrm{d}\left(\log \mathrm{q}_{\mathrm{i}}\right)=\theta_{\mathrm{i}} \mathrm{d}(\log \mathrm{Q})+\sum_{\mathrm{j}=1}^{\mathrm{n}} \pi_{\mathrm{ij}} \mathrm{d}\left(\log \mathrm{p}_{\mathrm{j}}\right)
$$

where $\theta_{i}=\partial\left(p_{i} q_{i}\right) / \partial M$ is the $i^{\text {th }}$ marginal share, $d(\log Q)=d(\log M)-d(\log P)$ is the change in real income, with $\mathrm{d}(\log \mathrm{P})=\sum_{\mathrm{j}=1}^{\mathrm{n}} \mathrm{w}_{\mathrm{j}} \mathrm{d}\left(\log \mathrm{p}_{\mathrm{j}}\right)$ the Divisia price index, and $\pi_{\mathrm{ij}}=\left(\mathrm{p}_{\mathrm{i}} \mathrm{p}_{\mathrm{j}} / \mathrm{M}\right) \mathrm{s}_{\mathrm{ij}}$ is the $(\mathrm{i}, \mathrm{j})^{\text {th }}$ Slutsky coefficient. In this formulation, the income effects of price changes transform money income into real income.

\section{Selvanathan's Model}

The $\mathrm{i}^{\text {th }}$ equation of the infinitesimal-change version of Selvanathan's (1985) model is

$$
\mathrm{w}_{\mathrm{i}}\left[\mathrm{d}\left(\log \mathrm{q}_{\mathrm{i}}\right)-\mathrm{d}(\log \mathrm{Q})\right]=\beta_{\mathrm{i}} \mathrm{d}(\log \mathrm{Q})+\kappa \mathrm{w}_{\mathrm{i}}\left[\mathrm{d}\left(\log \mathrm{p}_{\mathrm{i}}\right)-\mathrm{d}(\log \mathrm{P})\right],
$$

where $\beta_{\mathrm{i}}=\theta_{\mathrm{i}}-\mathrm{w}_{\mathrm{i}}$ is an income coefficient and $\kappa<0$ is the negative of the elasticity of substitution. The whole model comprises $\mathrm{n}$ demand equations of the above form and an attractive feature is its simplicity: While the model satisfies the usual requirements of homogeneity, symmetry and adding up, only the own-relative price appears in each equation. Moreover, the model is linear in the parameters and as it contains only $\mathrm{n}$ free parameters, it is parsimonious.

The substitution term in model (A2.1) is expressed in terms of relative prices. This can also be expressed in absolute pries by writing the substitution term as

$$
\begin{aligned}
\kappa \mathrm{w}_{\mathrm{i}}\left[\mathrm{d}\left(\log \mathrm{p}_{\mathrm{i}}\right)-\mathrm{d}(\log \mathrm{P})\right] & =\kappa \mathrm{w}_{\mathrm{i}}\left[\mathrm{d}\left(\log \mathrm{p}_{\mathrm{i}}\right)-\sum_{\mathrm{j}=1}^{\mathrm{n}} \mathrm{w}_{\mathrm{j}} \mathrm{d}\left(\log \mathrm{p}_{\mathrm{j}}\right)\right] \\
& =\kappa \mathrm{w}_{\mathrm{i}} \sum_{\mathrm{j}=1}^{\mathrm{n}}\left[\delta_{\mathrm{ij}}-\mathrm{w}_{\mathrm{j}}\right] \mathrm{d}\left(\log \mathrm{p}_{\mathrm{j}}\right)=\sum_{\mathrm{j}=1}^{\mathrm{n}} \pi_{\mathrm{ij}} \mathrm{d}\left(\log \mathrm{p}_{\mathrm{j}}\right),
\end{aligned}
$$

where $\delta_{\mathrm{ij}}$ is the Kronecker delta and

$$
\pi_{\mathrm{ij}}=\kappa \mathrm{w}_{\mathrm{i}}\left(\delta_{\mathrm{ij}}-\mathrm{w}_{\mathrm{j}}\right)
$$

is the $(i, j)^{\text {th }}$ Slutsky coefficient implied by this model. For $i, j=1, \ldots, n$, these coefficients satisfy $\sum_{\mathrm{j}=1}^{\mathrm{n}} \pi_{\mathrm{ij}}=0$ (homogeneity), $\pi_{\mathrm{ij}}=\pi_{\mathrm{ji}}$ (symmetry) and $\sum_{\mathrm{i}=1}^{\mathrm{n}} \pi_{\mathrm{ij}}=0$ (adding up). 


\section{The Welfare Cost}

If on account of some distortion, the $\mathrm{n}$ prices change by $\mathrm{dp}_{1}, \ldots, \mathrm{dp}_{\mathrm{n}}$, then Harberger's (1964) measure of the welfare cost is $\mathrm{W}=-(1 / 2) \sum_{\mathrm{i}=1}^{\mathrm{n}} \sum_{\mathrm{j}=1}^{\mathrm{n}}\left(\mathrm{dp}_{\mathrm{i}}\right) \mathrm{s}_{\mathrm{ij}}\left(\mathrm{dp} \mathrm{p}_{\mathrm{j}}\right)$. Using $\pi_{\mathrm{ij}}=\left(\mathrm{p}_{\mathrm{i}} \mathrm{p}_{\mathrm{j}} / \mathrm{M}\right) \mathrm{s}_{\mathrm{ij}}$, this can be expressed equivalently as

$$
\frac{W}{M}=-\frac{1}{2} \sum_{i=1}^{n} \sum_{j=1}^{n} d\left(\log p_{i}\right) \pi_{i j} d\left(\log p_{j}\right) .
$$

This states that the welfare cost (measured as a fraction of income) is proportional to a quadratic form in the $n$ price log-changes, with proportionality factor $-1 / 2$. The matrix in this quadratic form

is the $\mathrm{n} \times \mathrm{n}$ Slutsky matrix $\left[\pi_{\mathrm{ij}}\right]$. As this matrix is negative semidefinite with rank $\mathrm{n}-1$ (it is singular because of homogeneity), the welfare cost is nonnegative; it is zero when all prices change proportionately.

When the Slutsky coefficients take the form (A2.2), the cost (A2.3) becomes

$$
\frac{W}{M}=-\frac{\kappa}{2} \sum_{i=1}^{n} \sum_{j=1}^{n} d\left(\log p_{i}\right) w_{i}\left(\delta_{i j}-w_{j}\right) d\left(\log p_{j}\right)=-\frac{\kappa}{2} \sum_{i=1}^{n} w_{i} d\left(\log p_{i}\right)\left[d\left(\log p_{i}\right)-d(\log P)\right] .
$$

The term on the far right of the above can be written as

$$
-\frac{\kappa}{2}\left\{\sum_{i=1}^{n} \mathrm{w}_{\mathrm{i}}\left[\mathrm{d}\left(\log \mathrm{p}_{\mathrm{i}}\right)-\mathrm{d}(\log \mathrm{P})\right]^{2}+\sum_{\mathrm{i}=1}^{\mathrm{n}} \mathrm{w}_{\mathrm{i}} \mathrm{d}(\log \mathrm{P})\left[\mathrm{d}\left(\log \mathrm{p}_{\mathrm{i}}\right)-\mathrm{d}(\log \mathrm{P})\right]\right\} .
$$

As $\sum_{\mathrm{i}} \mathrm{w}_{\mathrm{i}} \mathrm{d}(\log \mathrm{P})\left[\mathrm{d}\left(\log \mathrm{p}_{\mathrm{i}}\right)-\mathrm{d}(\log \mathrm{P})\right]=0$, we have

$$
\frac{\mathrm{W}}{\mathrm{M}}=-\frac{\kappa}{2} \sum_{\mathrm{i}=1}^{\mathrm{n}} \mathrm{w}_{\mathrm{i}}\left[\mathrm{d}\left(\log \mathrm{p}_{\mathrm{i}}\right)-\mathrm{d}(\log \mathrm{P})\right]^{2}=-\frac{\kappa}{2} \Pi,
$$

where $\Pi$ is the variance of prices. This verifies equation (18).

\section{An Alternative Approach}

Another way of establishing result (A2.4) is as follows. The Slutsky matrix implied by Selvanathan's model is $\kappa \mathbf{W}\left(\mathbf{I}-\mathfrak{\imath \imath}^{\prime} \mathbf{W}\right)$, where $\mathbf{W}$ is an $\mathrm{n} \times \mathrm{n}$ diagonal matrix with the budget shares on the main diagonal, $\mathbf{I}$ is an identity matrix and $\mathbf{\imath}$ is a vector of unit elements. Let $\mathbf{p}=\left[\mathrm{d}\left(\log \mathrm{p}_{\mathrm{i}}\right)\right]$ be a vector of the $n$ price log-changes, so that $\mathbf{p}^{\prime} \mathbf{W} \mathbf{p}=\sum_{\mathrm{i}=1}^{\mathrm{n}} \mathrm{w}_{\mathrm{i}}\left[\mathrm{d}\left(\log \mathbf{p}_{\mathrm{i}}\right)\right]^{2}$ and $\mathbf{p}^{\prime} \mathbf{W} \imath \imath^{\prime} \mathbf{W} \mathbf{p}=[\mathrm{d}(\log \mathrm{P})]^{2}$. Then,

$$
\frac{\mathrm{W}}{\mathrm{M}}=-\frac{\kappa}{2} \mathbf{p}^{\prime} \mathbf{W}\left(\mathbf{I}-\mathfrak{u}^{\prime} \mathbf{W}\right) \mathbf{p}=-\frac{\kappa}{2}\left\{\sum_{\mathrm{i}=1}^{\mathrm{n}} \mathrm{W}_{\mathrm{i}}\left[\mathrm{d}\left(\log \mathrm{p}_{\mathrm{i}}\right)\right]^{2}-[\mathrm{d}(\log \mathrm{P})]^{2}\right\},
$$

which equals $-(\kappa / 2) \Pi$. 


\begin{tabular}{|c|c|c|c|c|c|c|c|c|c|c|c|c|}
\hline Country & $\begin{array}{l}\overrightarrow{8} \\
\\
\end{array}$ & 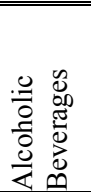 & $\begin{array}{l}\stackrel{\infty}{\Xi} \\
\text { 竞 } \\
0\end{array}$ & $\begin{array}{l}00 \\
.0 \\
0 \\
0 \\
0\end{array}$ & 先 & 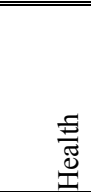 & 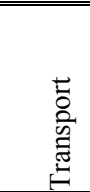 & 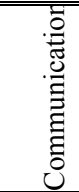 & 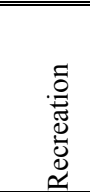 & 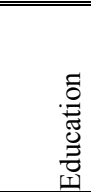 & 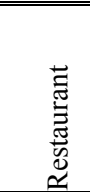 & 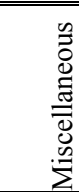 \\
\hline 1. United States & 6.24 & 1.96 & 4.19 & 16.01 & 4.40 & 18.26 & 10.62 & 1.55 & 8.61 & 8.50 & 5.64 & 14.02 \\
\hline 2. Luxembourg & 6.88 & 7.66 & 2.81 & 15.50 & 5.38 & 10.63 & 13.67 & 0.97 & 7.60 & 9.97 & 5.38 & 13.54 \\
\hline 3. Iceland & 8.94 & 3.04 & 3.45 & 15.40 & 4.94 & 12.65 & 13.51 & 1.91 & 10.95 & 9.76 & 5.93 & 9.51 \\
\hline 4. Norway & 9.73 & 3.10 & 4.07 & 14.94 & 4.47 & 13.48 & 10.71 & 2.37 & 10.95 & 7.72 & 4.17 & 14.29 \\
\hline 5. UK & 7.13 & 2.96 & 4.64 & 15.50 & 4.60 & 10.02 & 11.92 & 1.77 & 10.83 & 5.99 & 9.38 & 15.25 \\
\hline 6. Austria & 8.74 & 2.39 & 5.22 & 16.69 & 6.06 & 9.85 & 10.75 & 2.16 & 10.25 & 7.81 & 9.77 & 10.32 \\
\hline 7. Switzerland & 9.27 & 3.05 & 3.52 & 20.48 & 3.94 & 13.26 & 6.94 & 2.37 & 8.50 & 7.91 & 7.01 & 13.74 \\
\hline 8. Canada & 7.69 & 3.18 & 3.77 & 19.21 & 5.01 & 11.78 & 11.56 & 1.90 & 9.11 & 7.91 & 5.69 & 13.20 \\
\hline 9. Netherlands & 8.19 & 2.19 & 4.01 & 17.64 & 4.83 & 10.67 & 8.90 & 3.49 & 8.83 & 7.46 & 3.93 & 19.87 \\
\hline 10. Sweden & 8.27 & 2.43 & 3.65 & 19.21 & 3.57 & 11.74 & 9.15 & 2.20 & 9.69 & 10.20 & 3.53 & 16.36 \\
\hline 11. France & 10.58 & 2.37 & 3.71 & 19.72 & 4.58 & 12.04 & 11.35 & 2.15 & 8.83 & 7.11 & 4.77 & 12.80 \\
\hline 12. Australia & 8.55 & 3.53 & 3.22 & 18.32 & 5.62 & 11.83 & 10.15 & 2.44 & 10.21 & 9.40 & 6.77 & 9.97 \\
\hline 13. Denmark & 8.08 & 2.79 & 3.50 & 19.33 & 4.20 & 11.02 & 9.96 & 1.55 & 9.23 & 9.10 & 3.62 & 17.63 \\
\hline 14. Belgium & 10.29 & 2.75 & 4.16 & 17.73 & 4.26 & 13.01 & 11.36 & 1.74 & 7.85 & 8.95 & 3.98 & 13.92 \\
\hline 15. Germany & 9.14 & 2.88 & 4.30 & 19.77 & 5.63 & 12.65 & 11.24 & 2.25 & 8.29 & 5.84 & 4.38 & 13.63 \\
\hline 16. Hong Kong & 8.90 & 0.72 & 9.87 & 17.79 & 5.06 & 8.50 & 6.35 & 2.95 & 11.47 & 7.60 & 9.19 & 11.60 \\
\hline 17. Ireland & 4.60 & 4.08 & 4.07 & 16.60 & 5.40 & 10.11 & 9.77 & 2.71 & 6.85 & 10.11 & 12.30 & 13.41 \\
\hline 18. Japan & 12.26 & 2.51 & 2.81 & 20.43 & 4.73 & 11.50 & 8.98 & 2.69 & 7.77 & 6.15 & 6.47 & 13.70 \\
\hline 19. Taiwan & 14.82 & 2.22 & 3.63 & 15.12 & 5.67 & 8.37 & 10.14 & 3.17 & 8.31 & 10.82 & 7.60 & 10.12 \\
\hline 20. Cyprus & 13.71 & 5.42 & 5.57 & 12.83 & 4.91 & 5.99 & 12.74 & 1.76 & 7.74 & 7.29 & 11.09 & 10.95 \\
\hline 21. Finland & 9.31 & 3.76 & 3.61 & 18.87 & 4.08 & 11.71 & 9.62 & 2.11 & 9.81 & 8.06 & 4.87 & 14.18 \\
\hline 22. Spain & 11.77 & 2.42 & 4.67 & 13.71 & 4.45 & 10.43 & 9.88 & 2.20 & 8.67 & 6.48 & 15.60 & 9.72 \\
\hline 23. Italy & 12.31 & 2.19 & 6.60 & 17.09 & 6.35 & 11.83 & 11.08 & 2.32 & 6.29 & 6.50 & 8.14 & 9.32 \\
\hline 24. Greece & 13.84 & 4.24 & 9.27 & 14.18 & 5.70 & 8.30 & 7.85 & 2.20 & 5.66 & 5.90 & 17.00 & 5.86 \\
\hline 25. New Zealand & 11.47 & 4.13 & 3.69 & 18.17 & 5.36 & 10.09 & 11.38 & 2.40 & 11.53 & 7.31 & 6.25 & 8.22 \\
\hline 26. Israel & 12.88 & 2.04 & 2.79 & 19.34 & 5.74 & 9.70 & 9.60 & 3.16 & 7.80 & 11.77 & 4.07 & 11.10 \\
\hline 27. Malta & 13.91 & 2.62 & 5.21 & 9.35 & 7.56 & 7.89 & 11.85 & 4.02 & 9.78 & 6.74 & 11.30 & 9.76 \\
\hline 28. Singapore & 8.22 & 2.29 & 3.54 & 14.18 & 5.99 & 8.44 & 16.58 & 2.35 & 12.20 & 7.99 & 7.53 & 10.70 \\
\hline 29. Qatar & 13.63 & 0.25 & 6.16 & 17.19 & 6.44 & 8.82 & 15.31 & 4.62 & 3.27 & 17.98 & 1.55 & 4.77 \\
\hline 30. Slovenia & 11.93 & 4.09 & 4.72 & 15.59 & 4.91 & 10.81 & 12.97 & 2.90 & 9.01 & 8.42 & 5.36 & 9.29 \\
\hline 31. Portugal & 13.15 & 2.94 & 5.97 & 11.45 & 5.58 & 12.19 & 11.60 & 2.41 & 7.30 & 8.55 & 8.57 & 10.29 \\
\hline 32. Brunei & 18.36 & 0.53 & 4.41 & 12.13 & 4.38 & 5.29 & 15.10 & 5.48 & 7.67 & 15.95 & 5.08 & 5.64 \\
\hline 33. Kuwait & 14.77 & 0.20 & 8.07 & 18.37 & 13.40 & 5.60 & 12.33 & 2.55 & 4.09 & 12.80 & 2.38 & 5.43 \\
\hline 34. Czech Rep. & 13.09 & 6.45 & 3.95 & 18.08 & 4.26 & 10.57 & 9.37 & 2.82 & 10.61 & 7.48 & 5.33 & 7.98 \\
\hline 35. Hungary & 13.32 & 6.59 & 2.85 & 14.68 & 5.28 & 10.81 & 12.55 & 3.59 & 7.89 & 7.73 & 3.96 & 10.75 \\
\hline 36. Bahrain & 18.96 & 0.52 & 6.83 & 18.19 & 9.33 & 11.11 & 9.97 & 2.25 & 3.38 & 11.59 & 2.19 & 5.69 \\
\hline 37. Korea & 13.66 & 2.13 & 3.74 & 15.12 & 3.59 & 8.28 & 9.66 & 4.90 & 6.66 & 10.54 & 6.69 & 15.03 \\
\hline 38. Estonia & 15.36 & 6.81 & 6.12 & 16.10 & 4.67 & 7.61 & 10.65 & 2.57 & 8.78 & 7.39 & 5.79 & 8.16 \\
\hline 39. Slovakia & 15.66 & 4.48 & 3.67 & 22.30 & 4.67 & 9.17 & 7.50 & 3.12 & 8.61 & 5.79 & 5.82 & 9.23 \\
\hline 40. Lithuania & 22.92 & 5.70 & 7.05 & 12.16 & 4.84 & 9.06 & 12.86 & 2.27 & 6.38 & 6.92 & 2.68 & 7.17 \\
\hline 41. Poland & 17.81 & 5.60 & 4.03 & 20.19 & 3.82 & 8.68 & 7.42 & 2.85 & 7.06 & 7.94 & 2.42 & 12.17 \\
\hline 42. Croatia & 19.28 & 3.87 & 4.62 & 14.75 & 7.41 & 9.39 & 9.06 & 2.89 & 7.70 & 6.89 & 7.50 & 6.63 \\
\hline 43. Macao & 13.25 & 0.89 & 4.91 & 13.93 & 2.22 & 8.10 & 8.71 & 5.63 & 15.33 & 8.35 & 12.26 & 6.42 \\
\hline 44. Latvia & 19.22 & 6.09 & 6.11 & 18.22 & 3.15 & 7.66 & 9.72 & 3.62 & 8.32 & 8.19 & 4.69 & 5.00 \\
\hline 45. Lebanon & 27.77 & 2.07 & 6.01 & 10.02 & 6.27 & 8.01 & 7.23 & 1.36 & 2.92 & 17.15 & 5.17 & 6.03 \\
\hline
\end{tabular}


TABLE A1 (continued)

BUDGET SHARES IN 132 COUNTRIES IN $2005(\times 100)$

\begin{tabular}{|c|c|c|c|c|c|c|c|c|c|c|c|c|}
\hline Country & $\begin{array}{l}\overrightarrow{0} \\
8 \\
0 \\
\end{array}$ & 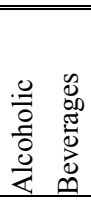 & $\begin{array}{l}.00 \\
. \Xi \\
0 \\
0\end{array}$ & $\begin{array}{l}00 \\
.0 \\
0 \\
0 \\
0 \\
0\end{array}$ & 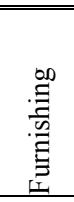 & 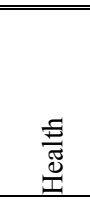 & 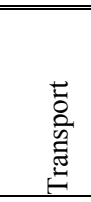 & 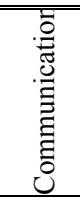 & 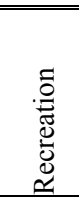 & 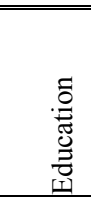 & 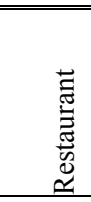 & 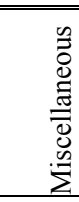 \\
\hline 46. Mexico & 21.98 & 2.34 & 2.57 & 15.40 & 6.84 & 7.03 & 15.90 & 1.79 & 3.00 & 8.80 & 6.45 & 7.89 \\
\hline 47. Belarus & 34.67 & 4.59 & 5.86 & 11.39 & 3.35 & 9.06 & 6.26 & 3.62 & 4.33 & 10.36 & 2.08 & 4.42 \\
\hline 48. Kazakhstan & 18.61 & 2.90 & 8.76 & 25.72 & 2.78 & 9.64 & 8.44 & 2.03 & 4.79 & 9.22 & 2.73 & 4.37 \\
\hline 49. Mauritius & 23.44 & 6.75 & 4.73 & 19.90 & 6.27 & 5.21 & 10.91 & 2.47 & 5.26 & 7.72 & 2.79 & 4.56 \\
\hline 50. Russia & 25.53 & 6.13 & 9.36 & 9.64 & 4.05 & 7.74 & 10.92 & 4.27 & 6.26 & 5.67 & 2.83 & 7.61 \\
\hline 51. Bulgaria & 19.51 & 3.29 & 2.87 & 18.10 & 3.54 & 7.82 & 16.07 & 5.46 & 5.22 & 5.75 & 8.00 & 4.37 \\
\hline 52. Iran & 23.39 & 0.67 & 6.24 & 24.52 & 5.58 & 8.42 & 9.24 & 2.45 & 3.59 & 7.64 & 1.55 & 6.70 \\
\hline 53. Romania & 24.95 & 4.37 & 3.08 & 19.78 & 4.29 & 8.21 & 14.78 & 1.76 & 4.35 & 6.02 & 4.40 & 4.00 \\
\hline 54. Oman & 22.11 & 0.49 & 6.32 & 17.26 & 5.11 & 5.39 & 12.20 & 3.82 & 2.18 & 11.70 & 2.26 & 11.17 \\
\hline 55. Argentina & 22.49 & 3.64 & 4.27 & 14.38 & 4.86 & 10.68 & 9.14 & 3.68 & 6.42 & 6.00 & 6.98 & 7.46 \\
\hline 56. Serbia & 25.64 & 4.62 & 3.84 & 21.49 & 4.47 & 8.18 & 8.27 & 3.35 & 4.48 & 5.34 & 2.37 & 7.95 \\
\hline 57. Saudi Arabia & 18.46 & 0.36 & 6.38 & 14.78 & 8.75 & 9.03 & 9.70 & 2.33 & 3.48 & 19.12 & 3.97 & 3.63 \\
\hline 58. Chile & 16.22 & 2.65 & 7.09 & 15.37 & 7.32 & 10.57 & 13.59 & 2.91 & 4.03 & 9.00 & 2.98 & 8.26 \\
\hline 59. Uruguay & 19.02 & 3.54 & 4.86 & 19.52 & 6.05 & 11.39 & 11.70 & 3.04 & 4.44 & 5.51 & 4.45 & 6.48 \\
\hline 60. Bosnia & 28.51 & 5.68 & 5.17 & 13.32 & 6.44 & 8.34 & 7.65 & 2.45 & 4.18 & 5.27 & 6.56 & 6.42 \\
\hline 61. Macedonia & 30.91 & 3.09 & 5.50 & 17.88 & 3.86 & 6.79 & 8.96 & 6.55 & 2.31 & 5.54 & 3.39 & 5.21 \\
\hline 62. Ukraine & 32.05 & 5.08 & 4.32 & 8.84 & 3.25 & 8.69 & 10.90 & 3.69 & 5.30 & 9.56 & 2.70 & 5.62 \\
\hline 63. South Africa & 17.61 & 5.03 & 5.02 & 11.17 & 6.67 & 10.88 & 15.09 & 2.09 & 4.06 & 10.16 & 2.28 & 9.95 \\
\hline 64. Malaysia & 17.28 & 1.48 & 2.21 & 17.46 & 4.66 & 4.85 & 12.67 & 5.23 & 4.13 & 9.02 & 7.62 & 13.40 \\
\hline 65. Turkey & 23.06 & 3.84 & 5.75 & 24.02 & 6.28 & 3.80 & 11.68 & 4.00 & 2.36 & 5.80 & 4.06 & 5.34 \\
\hline 66. Montenegro & 32.15 & 3.62 & 5.15 & 23.02 & 3.62 & 7.06 & 6.58 & 4.32 & 2.76 & 4.53 & 1.25 & 5.95 \\
\hline 67. Brazil & 15.50 & 2.25 & 4.10 & 16.27 & 5.67 & 12.00 & 11.87 & 4.03 & 4.32 & 8.39 & 3.68 & 11.90 \\
\hline 68. Venezuela & 26.07 & 2.92 & 3.98 & 11.07 & 5.18 & 8.83 & 9.08 & 4.61 & 4.17 & 10.44 & 8.15 & 5.49 \\
\hline 69. Thailand & 15.87 & 4.41 & 6.96 & 7.17 & 6.06 & 8.32 & 14.59 & 1.32 & 5.91 & 8.92 & 14.86 & 5.62 \\
\hline 70. Albania & 24.63 & 4.78 & 4.51 & 19.13 & 5.43 & 5.59 & 11.82 & 4.01 & 5.50 & 3.41 & 5.35 & 5.83 \\
\hline 71. Colombia & 24.32 & 3.98 & 4.40 & 14.17 & 5.19 & 10.66 & 10.74 & 2.81 & 3.52 & 8.53 & 5.79 & 5.87 \\
\hline 72. Ecuador & 25.92 & 2.08 & 6.23 & 11.43 & 6.83 & 7.08 & 14.13 & 4.47 & 6.01 & 8.89 & 2.97 & 3.97 \\
\hline 73. Jordan & 28.87 & 3.06 & 5.40 & 17.10 & 3.95 & 7.73 & 8.93 & 3.66 & 1.69 & 11.67 & 2.85 & 5.10 \\
\hline 74. Tunisia & 24.78 & 3.60 & 8.62 & 12.96 & 7.17 & 5.94 & 9.00 & 0.96 & 2.34 & 6.06 & 12.77 & 5.80 \\
\hline 75. Peru & 29.24 & 1.91 & 5.96 & 8.50 & 5.15 & 7.03 & 8.39 & 2.47 & 4.62 & 9.64 & 8.01 & 9.08 \\
\hline 76. Egypt & 41.65 & 2.74 & 7.71 & 12.88 & 3.63 & 4.89 & 3.96 & 2.61 & 2.53 & 7.51 & 3.09 & 6.80 \\
\hline 77. Moldova & 24.20 & 7.76 & 4.49 & 15.33 & 6.98 & 4.87 & 9.92 & 4.65 & 6.19 & 7.58 & 1.65 & 6.38 \\
\hline 78. Maldives & 22.95 & 2.02 & 3.54 & 29.70 & 3.49 & 9.44 & 3.41 & 3.12 & 3.52 & 14.04 & 1.10 & 3.68 \\
\hline 79. Gabon & 36.34 & 2.01 & 5.21 & 14.75 & 3.12 & 6.71 & 6.37 & 4.07 & 2.54 & 10.74 & 2.88 & 5.26 \\
\hline 80. Fiji & 26.25 & 2.97 & 2.35 & 25.80 & 9.49 & 5.51 & 7.61 & 0.39 & 4.96 & 7.36 & 2.84 & 4.49 \\
\hline 81. Georgia & 36.70 & 0.90 & 8.54 & 4.16 & 3.79 & 7.63 & 2.48 & 1.88 & 6.01 & 23.43 & 0.45 & 4.03 \\
\hline 82. Botswana & 21.94 & 8.81 & 6.18 & 9.04 & 7.40 & 6.49 & 13.02 & 2.92 & 2.42 & 16.57 & 0.19 & 5.03 \\
\hline 83. Namibia & 25.96 & 2.65 & 5.14 & 12.15 & 5.08 & 8.41 & 9.67 & 0.71 & 2.67 & 14.32 & 4.29 & 8.95 \\
\hline 84. Swaziland & 41.90 & 0.88 & 6.17 & 13.56 & 7.08 & 7.30 & 6.85 & 1.32 & 3.24 & 8.27 & 0.64 & 2.78 \\
\hline 85. Syria & 41.72 & 0.26 & 8.69 & 23.91 & 3.17 & 8.15 & 3.29 & 0.31 & 1.36 & 6.80 & 1.83 & 0.50 \\
\hline 86. Bolivia & 27.75 & 1.54 & 3.08 & 12.07 & 5.31 & 7.56 & 17.89 & 2.16 & 1.36 & 11.18 & 7.38 & 2.72 \\
\hline 87. Eq. Guinea & 39.49 & 2.37 & 5.39 & 14.28 & 3.96 & 7.40 & 8.35 & 3.91 & 1.64 & 3.91 & 3.56 & 5.73 \\
\hline 88. Paraguay & 32.30 & 2.50 & 7.88 & 11.68 & 5.17 & 5.24 & 11.37 & 2.41 & 6.19 & 5.41 & 4.19 & 5.67 \\
\hline 89. Cape Verde & 28.84 & 1.69 & 3.39 & 26.96 & 4.87 & 3.52 & 6.11 & 3.00 & 3.06 & 11.73 & 2.75 & 4.08 \\
\hline 90. Bhutan & 34.53 & 2.60 & 6.40 & 16.59 & 5.57 & 12.95 & 1.90 & 0.40 & 3.39 & 5.97 & 0.07 & 9.63 \\
\hline
\end{tabular}

(Continued on next page) 
TABLE A1 (continued)

BUDGET SHARES IN 132 COUNTRIES IN $2005(\times 100)$

\begin{tabular}{|c|c|c|c|c|c|c|c|c|c|c|c|c|}
\hline Country & $\begin{array}{l}\text { T. } \\
8 \\
\end{array}$ & 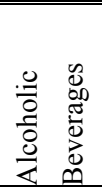 & $\begin{array}{l}\stackrel{0}{\Xi} \\
\stackrel{0}{0} \\
\end{array}$ & 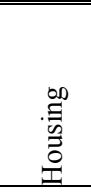 & 离 & 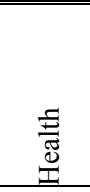 & 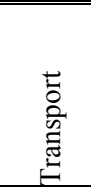 & 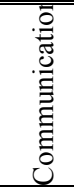 & 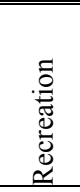 & 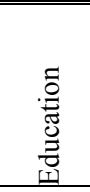 & 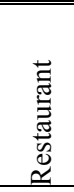 & 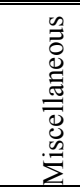 \\
\hline 91. Kyrgyzstan & 40.82 & 8.32 & 7.92 & 7.04 & 3.00 & 4.19 & 9.16 & 2.65 & 2.43 & 5.98 & 2.71 & 5.78 \\
\hline 92. Sri Lanka & 36.42 & 4.08 & 9.17 & 7.52 & 6.26 & 3.36 & 16.76 & 0.96 & 3.72 & 2.92 & 1.69 & 7.15 \\
\hline 93. Iraq & 32.12 & 0.79 & 5.20 & 15.73 & 7.66 & 15.19 & 9.25 & 1.16 & 1.00 & 9.17 & 0.72 & 2.01 \\
\hline 94. Mongolia & 35.88 & 2.30 & 10.81 & 16.80 & 3.65 & 5.26 & 6.31 & 1.88 & 3.28 & 10.41 & 0.55 & 2.87 \\
\hline 95. Philippines & 43.90 & 1.96 & 2.16 & 13.94 & 1.86 & 3.41 & 5.49 & 3.98 & 1.09 & 9.05 & 3.14 & 10.02 \\
\hline 96. Indonesia & 41.60 & 1.87 & 3.55 & 20.20 & 2.64 & 3.02 & 6.52 & 1.83 & 1.72 & 5.56 & 6.17 & 5.33 \\
\hline 97. Pakistan & 48.77 & 0.93 & 7.49 & 13.67 & 2.40 & 7.24 & 5.18 & 1.94 & 2.69 & 4.53 & 0.69 & 4.47 \\
\hline 98. Morocco & 31.09 & 2.85 & 5.03 & 13.00 & 4.29 & 5.36 & 8.83 & 5.06 & 3.17 & 10.44 & 5.69 & 5.20 \\
\hline 99. Lesotho & 35.48 & 3.51 & 12.55 & 7.35 & 6.57 & 7.28 & 5.75 & 1.79 & 1.60 & 13.31 & 0.20 & 4.63 \\
\hline 100. China & 24.12 & 2.05 & 6.30 & 14.66 & 3.92 & 6.21 & 4.03 & 4.17 & 4.65 & 9.79 & 5.23 & 14.86 \\
\hline 101. Vietnam & 31.34 & 2.28 & 3.54 & 15.15 & 4.81 & 8.13 & 9.58 & 0.86 & 4.80 & 9.22 & 6.74 & 3.54 \\
\hline 102. India & 33.69 & 2.13 & 5.21 & 12.13 & 2.76 & 7.32 & 15.32 & 1.52 & 1.91 & 5.71 & 1.86 & 10.44 \\
\hline 103. Cambodia & 47.20 & 3.78 & 1.82 & 12.55 & 1.77 & 7.64 & 7.22 & 0.25 & 2.42 & 6.00 & 4.76 & 4.59 \\
\hline 104. Yemen & 41.06 & 2.03 & 8.73 & 16.49 & 4.04 & 3.78 & 5.16 & 0.68 & 1.26 & 6.43 & 2.42 & 7.92 \\
\hline 105. Sudan & 55.60 & 1.50 & 4.69 & 14.30 & 5.82 & 2.02 & 8.17 & 0.10 & 2.95 & 1.68 & 0.10 & 3.06 \\
\hline 106. Laos & 47.35 & 5.57 & 1.75 & 12.37 & 2.86 & 3.09 & 10.54 & 0.44 & 2.97 & 6.84 & 2.97 & 3.25 \\
\hline 107. Djibouti & 33.64 & 12.98 & 2.51 & 16.32 & 6.94 & 4.25 & 7.91 & 0.45 & 0.35 & 7.91 & 4.04 & 2.69 \\
\hline 108. Kenya & 33.27 & 3.11 & 2.96 & 7.35 & 4.48 & 7.73 & 11.67 & 2.77 & 5.86 & 11.80 & 4.53 & 4.47 \\
\hline 109. Sao Tome. & 53.71 & 4.44 & 3.86 & 9.00 & 3.32 & 5.40 & 9.63 & 1.25 & 1.44 & 4.69 & 1.25 & 2.00 \\
\hline 110. Congo, Rep. & 37.52 & 3.87 & 2.45 & 13.03 & 3.38 & 5.95 & 7.90 & 4.91 & 2.12 & 8.09 & 7.72 & 3.06 \\
\hline 111. Cameroon & 43.37 & 2.53 & 9.97 & 8.79 & 10.43 & 2.34 & 7.04 & 1.28 & 1.62 & 4.12 & 6.13 & 2.37 \\
\hline 112. Nigeria & 56.67 & 1.02 & 5.85 & 11.35 & 7.03 & 3.04 & 4.71 & 0.33 & 1.31 & 4.30 & 0.71 & 3.69 \\
\hline 113. Senegal & 48.93 & 3.05 & 5.24 & 9.96 & 6.20 & 5.24 & 3.89 & 5.39 & 2.29 & 5.12 & 0.97 & 3.72 \\
\hline 114. Chad & 55.05 & 1.49 & 1.62 & 2.31 & 7.16 & 1.37 & 19.42 & 0.85 & 4.71 & 1.81 & 0.52 & 3.69 \\
\hline 115. Nepal & 48.72 & 3.24 & 6.20 & 13.84 & 2.30 & 8.81 & 3.94 & 0.30 & 1.02 & 4.56 & 2.40 & 4.69 \\
\hline 116. Bangladesh & 49.92 & 2.37 & 5.78 & 17.37 & 3.67 & 3.65 & 4.09 & 0.47 & 0.77 & 5.65 & 2.23 & 4.04 \\
\hline 117. Benin & 43.59 & 2.39 & 9.19 & 10.34 & 3.16 & 2.91 & 7.34 & 1.74 & 2.17 & 4.57 & 7.89 & 4.72 \\
\hline 118. Ghana & 49.15 & 2.12 & 9.14 & 6.64 & 6.44 & 5.70 & 5.89 & 0.30 & 2.97 & 8.14 & 0.03 & 3.47 \\
\hline 119. Cote d'Ivoire & 43.28 & 3.21 & 3.54 & 9.71 & 8.42 & 4.22 & 11.14 & 2.93 & 3.53 & 3.99 & 1.46 & 4.58 \\
\hline 120. Sierra Leone & 42.42 & 2.79 & 7.22 & 6.58 & 2.56 & 14.35 & 2.68 & 2.56 & 3.12 & 9.87 & 1.11 & 4.75 \\
\hline 121. Madagascar & 57.03 & 3.08 & 4.06 & 14.21 & 4.60 & 4.41 & 3.13 & 0.45 & 0.70 & 5.87 & 1.32 & 1.14 \\
\hline 122. Togo & 48.59 & 4.19 & 5.22 & 6.56 & 2.70 & 3.77 & 16.02 & 2.04 & 1.95 & 3.94 & 2.32 & 2.70 \\
\hline 123. Burkina Faso & 41.98 & 9.19 & 3.28 & 9.35 & 8.51 & 2.86 & 7.81 & 1.09 & 1.82 & 4.42 & 5.64 & 4.06 \\
\hline 124. Guinea & 44.04 & 2.01 & 6.86 & 7.49 & 5.55 & 12.08 & 7.84 & 0.23 & 1.16 & 6.73 & 2.02 & 3.98 \\
\hline 125. Mali & 46.70 & 1.64 & 4.81 & 11.18 & 6.38 & 4.41 & 9.91 & 0.89 & 3.07 & 6.19 & 1.83 & 3.00 \\
\hline 126. Angola & 40.70 & 4.41 & 4.92 & 8.89 & 5.67 & 5.60 & 5.13 & 0.82 & 2.12 & 5.51 & 2.99 & 13.24 \\
\hline 127. Rwanda & 42.65 & 13.18 & 3.41 & 14.18 & 5.09 & 3.46 & 5.12 & 0.55 & 1.20 & 6.79 & 1.71 & 2.67 \\
\hline 128. CAR & 56.84 & 8.98 & 7.74 & 5.01 & 5.09 & 1.73 & 3.55 & 0.85 & 1.75 & 3.43 & 1.91 & 3.13 \\
\hline 129. Mozambique & 60.09 & 3.23 & 5.90 & 6.85 & 2.67 & 4.73 & 4.03 & 0.16 & 2.13 & 7.52 & 0.45 & 2.26 \\
\hline 130. Niger & 46.41 & 2.28 & 7.12 & 8.47 & 4.79 & 4.59 & 7.95 & 0.78 & 5.23 & 3.48 & 5.15 & 3.75 \\
\hline 131. Guinea-Biss. & 52.27 & 1.72 & 8.33 & 13.54 & 7.26 & 2.74 & 6.50 & 0.53 & 3.91 & 2.25 & 0.48 & 0.45 \\
\hline 132. Congo, D.R. & 62.22 & 2.02 & 5.00 & 11.95 & 2.80 & 3.99 & 3.41 & 0.82 & 0.91 & 2.99 & 1.39 & 2.50 \\
\hline Mean--All & 27.57 & 3.34 & 5.27 & 14.67 & 5.11 & 7.70 & 9.40 & 2.42 & 4.94 & 7.99 & 4.46 & 7.13 \\
\hline --Rich & 10.53 & 3.22 & 4.42 & 16.86 & 5.03 & 10.58 & 10.57 & 2.48 & 8.98 & 8.08 & 7.23 & 12.02 \\
\hline --Poor & 33.08 & 3.38 & 5.55 & 13.97 & 5.14 & 6.77 & 9.02 & 2.40 & 3.63 & 7.96 & 3.56 & 5.54 \\
\hline
\end{tabular}

Note: Means exclude US. 


\section{RELATIVE PRICES IN 132 COUNTRIES IN 2005}

\begin{tabular}{|c|c|c|c|c|c|c|c|c|c|c|c|c|}
\hline Country & $\begin{array}{l}\text { D } \\
8 \\
\end{array}$ & 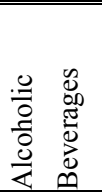 & $\begin{array}{l}\stackrel{0}{\Xi} \\
\stackrel{\Xi}{0} \\
0\end{array}$ & $\begin{array}{l}.00 \\
.0 \\
0 \\
0 \\
0\end{array}$ & 告 & 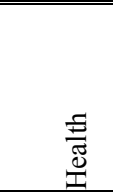 & 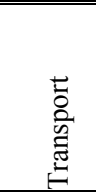 & 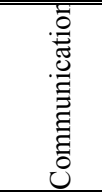 & 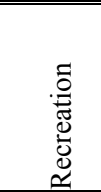 & 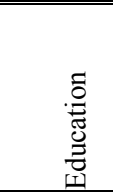 & 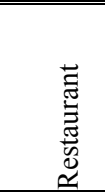 & 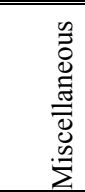 \\
\hline 1. United States & 0.00 & 0.00 & 0.00 & 0.00 & 0.00 & 0.00 & 0.00 & 0.00 & 0.00 & 0.00 & 0.00 & 0.00 \\
\hline 2. Luxembourg & 9.61 & -28.28 & 11.01 & -0.37 & 1.23 & -32.30 & 20.54 & -34.09 & 10.48 & 3.29 & 19.45 & -0.20 \\
\hline 3. Iceland & 19.83 & 30.93 & 21.76 & -14.45 & 3.12 & -34.24 & 26.65 & -31.14 & 16.49 & -53.79 & 51.10 & 3.63 \\
\hline 4. Norway & 20.15 & 42.92 & 14.99 & -33.22 & -4.78 & -34.36 & 51.29 & -28.87 & 12.30 & -43.80 & 39.28 & 10.46 \\
\hline 5. UK & .58 & 39.28 & 1.12 & -22.8 & 1.95 & -43.13 & 42.56 & -26.94 & 2.60 & -31 & 09 & -0.56 \\
\hline 6. Aus & 13.31 & -14.5 & 9.93 & -19 & 2 & -40 & 44 & -10.54 & 8.22 & -32 & 3 & 4.61 \\
\hline 7. Switz & 15.73 & -35.15 & -3.20 & 14.00 & -6. & -31.54 & 77 & -11.70 & 1.31 & -25 & 6 & 3.51 \\
\hline 8. Canada & 19.86 & 39.84 & 20.59 & -20.01 & 17.87 & -17.71 & 23 & -0.27 & 3.77 & -4 & 32 & -1.66 \\
\hline 9. Netherlands & -7.15 & -5.83 & 8.18 & 7.64 & -1.14 & -42.95 & 53.09 & -7.08 & 7.51 & -40.72 & 29.93 & 1.99 \\
\hline 10. Sweden & 12.35 & 9.37 & 14.05 & -9.69 & 8.19 & -32.76 & 46.06 & -44.23 & 14.50 & -38.34 & 37.93 & 9.66 \\
\hline 11. France & 7.03 & 1.37 & -2.99 & 0.99 & 6.67 & -38.49 & 33.52 & -0.27 & 10.25 & -45.27 & 35.88 & 2.12 \\
\hline 12. Australia & 15.50 & 35.77 & 0.13 & -6.32 & 18.79 & -27.98 & 26.42 & 16.70 & 9.25 & -50.20 & 22.86 & -0.45 \\
\hline 13. Denmark & 10.07 & -15.66 & -1.20 & -3.01 & 72 & -31.84 & 50.18 & -55.12 & 8.02 & -3 & 37 & 6.17 \\
\hline 14. Bel & 0 & -10.74 & 14 & 0.86 & 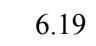 & -3 & 3 & 1.89 & 3 & 7 & & 0.35 \\
\hline 15. Germany & 6 & -9.98 & 10.52 & - & -1.27 & -43.50 & 37.33 & -2.74 & 11.08 & -1 & 96 & 0.33 \\
\hline 16. Hong K & 31.95 & 46.24 & -4.63 & 3 & 1 & -7 & 8.37 & 6.55 & -19.90 & -6 & 83 & -13.10 \\
\hline 17. Ireland & 46 & 35.16 & -10 . & & -4.18 & -3 & 29.01 & -11.19 & 35 & & 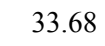 & 0.99 \\
\hline 18. Japan & 3.71 & -31.19 & 23.24 & -5.54 & 23.25 & -71.57 & 20.26 & -4.16 & -8.75 & -37 & 87 & 0.62 \\
\hline 19. Taiwan & 58.81 & 16.25 & 10.28 & 24.07 & 47.36 & -121.10 & 37.99 & -17.67 & -6.80 & -93.78 & 27.27 & -2.83 \\
\hline 20. Cyprus & 16.92 & 7.34 & 17.95 & -45.05 & 8.56 & -40.93 & 39.66 & -77.02 & 9.72 & -55.25 & 39.52 & -6.49 \\
\hline 21. Finland & 8.50 & 9.79 & 13.28 & -3.42 & -0.58 & -34.55 & 40.97 & -45.26 & 10.88 & -45.04 & 35.66 & 6.50 \\
\hline 22. Spain & 5.22 & -29.14 & 13.47 & -5.17 & 14.08 & -50.65 & 37.06 & 3.98 & 11.66 & -56 & 29.57 & -9.30 \\
\hline 23. Italy & 15.69 & -6.65 & 8.39 & -14.53 & 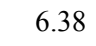 & -24.36 & 30.61 & -8.32 & .88 & -39.59 & 37 & -6.08 \\
\hline 24. Greece & 4.08 & -9.78 & 20.76 & -21.19 & 11.10 & -53.57 & 43 & 13.69 & 61 & -71.24 & 30.40 & -9.94 \\
\hline 25. New Z & 6 & 29. & 1 & 5.18 & 1 & - & 5 & 5 & 6 & -5 & 5.89 & -4.18 \\
\hline 26. Israel & 1 & 11. & 13 & -12 & & & & -15.20 & 1.53 & & & .37 \\
\hline 27. Malta & 14.87 & 22.15 & 40.48 & -68.56 & 33.14 & -68.23 & 55.81 & 17.25 & 11.10 & -71.26 & 85 & -12.23 \\
\hline 28. Singapore & 29.16 & 118.74 & 18.70 & 20.88 & 26.26 & -86.86 & 41.34 & -36.86 & -13.37 & -96.11 & 23.69 & -13.56 \\
\hline 29. Qatar & -6.37 & -40.37 & 6.30 & 125.73 & -23.08 & -68.78 & -40.99 & 10.87 & 1.12 & -38.15 & 41.56 & -31.96 \\
\hline 30. Slovenia & 21.92 & -10.89 & 41.50 & -26.85 & 15.29 & -46.89 & 45.30 & -8.61 & 18.59 & -48.24 & 18.43 & 1.62 \\
\hline 31. Portugal & 7.50 & -12.26 & 14.89 & -24.90 & .43 & -40.68 & 46.93 & 11.13 & 13.72 & -25.89 & 17.53 & -1.77 \\
\hline 32. Brunei & 5.77 & 30.48 & . & 22.28 & (2) & -89.11 & 14.70 & 30.75 & 55 & -109.13 & 1 & 1.25 \\
\hline 33. Kuwait & -13.30 & -47.53 & 34.68 & 56.18 & -15.73 & -57.43 & -30.09 & 9.08 & & -32.72 & 6 & -5.13 \\
\hline 34. Czech Rep. & 7.76 & 13.38 & $70.9^{9}$ & -33.87 & 40.7 & -67.14 & 67.11 & 61.9 & 10.50 & & 0 & -4 \\
\hline 35. Hungary & 26.40 & 8.37 & 57.20 & -45.05 & 22.79 & -61.72 & 74.90 & 39.72 & 16.02 & -84.69 & 35.40 & -5.20 \\
\hline 36. Bahrain & 3.66 & -26.34 & 2.17 & 80.20 & -14.81 & -54.44 & -14.91 & 16.54 & 9.85 & -60.41 & 55.77 & -22.78 \\
\hline 37. Korea & 60.99 & 3.57 & 31.97 & -4.92 & -5.75 & -83.25 & 29.25 & -34.73 & 12.42 & -53.77 & 46.45 & -7.66 \\
\hline 38. Estonia & 26.69 & 0.41 & 60.21 & -20.90 & 22.77 & -71.77 & 54.43 & 26.69 & 11.36 & -115.59 & 34.13 & -11.90 \\
\hline 39. Slovakia & 33.04 & 10.71 & 58.75 & -34.72 & 39.64 & -6 & 7 & 35 & 16.58 & -11 & 37 & -2.39 \\
\hline 40. Lithuania & 23.23 & 3.97 & 72.89 & -50.84 & 27.34 & -72.57 & 62.44 & 11.29 & 9.99 & -123.66 & 37.39 & -8.68 \\
\hline 41. Poland & 26.22 & 10.38 & 80.68 & -35.36 & 33.76 & -72.27 & 75.96 & 55.06 & 26.26 & -87.86 & 51.94 & 2.33 \\
\hline 42. Croatia & 31.70 & 17.25 & 53.33 & -63.09 & 27. & -64.05 & 77 & 87 & 16.71 & -91 & 49.43 & -7.41 \\
\hline 43. Macao & 34.48 & 2.64 & 4.69 & 13.46 & 33.81 & -95.73 & 28.97 & 17.11 & 0.19 & -93.47 & 40.06 & -4.85 \\
\hline 44. Latvia & 30.58 & -4.95 & 74.67 & -32.44 & 29.12 & -77.31 & 61.72 & 63.64 & 12.94 & -120.40 & 43.64 & -15.70 \\
\hline 45. Lebanon & 21.55 & 4.71 & 76.02 & -3.35 & 23.77 & -74.61 & -0.40 & 54.49 & 31.56 & -83.76 & 132.57 & 0.84 \\
\hline
\end{tabular}

(Continued on next page) 


\begin{tabular}{|c|c|c|c|c|c|c|c|c|c|c|c|c|}
\hline Country & $\begin{array}{l}7 \\
8 \\
8 \\
\end{array}$ & 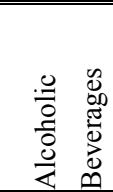 & $\begin{array}{l}\stackrel{\infty}{\Xi} \\
\pm \\
0 \\
0\end{array}$ & 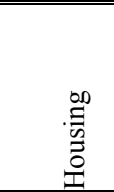 & 告 & 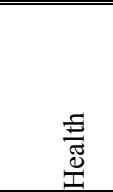 & 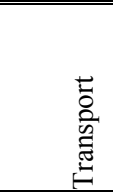 & 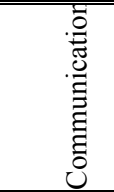 & 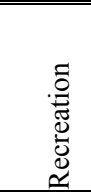 & 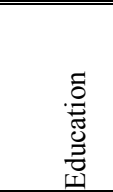 & 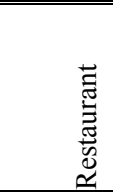 & 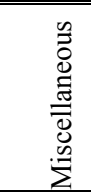 \\
\hline 46. Mexico & 12.59 & -18.70 & 12.06 & 19.37 & 2.30 & -41.47 & 23.34 & 44.14 & 15.06 & -98.04 & 25.03 & -10.17 \\
\hline 47. Belarus & 46.63 & 17.01 & 77.73 & -91.74 & 64.06 & -89.69 & 91.14 & -34.79 & 43.10 & -127.97 & 40.01 & 23.66 \\
\hline 48. Kazakhstan & 45.31 & -10.70 & 93.06 & -15.73 & 65.55 & -105.94 & 62.76 & 83.54 & 33.87 & -157.52 & 53.89 & 13.39 \\
\hline 49. Mauritius & 36.51 & 35.79 & 17.76 & -47.18 & 5.38 & -87.55 & 73.79 & -18.21 & 48.26 & -117.45 & 21.27 & 2.90 \\
\hline 50. Russia & 26.40 & -16.50 & 74.63 & -83.55 & 42.21 & -100.06 & 50.92 & 39.12 & 17.59 & -152.36 & 44.00 & 5.83 \\
\hline 51. Bulgaria & 33.24 & 0.03 & 55.32 & -48.61 & 33.73 & -92.66 & 68.78 & 74.60 & 13.84 & -156.76 & 7.01 & -14.25 \\
\hline 52. Iran & 7.39 & -4.41 & 22.95 & -7.86 & 46.10 & -142.18 & 41 & -154.81 & 30.25 & -99.66 & 77.47 & -9.75 \\
\hline 53. Romania & 34.73 & -2.63 & 52.05 & -28.95 & 17.82 & -97.40 & 61.19 & 42.34 & 4.00 & -122.10 & 20.42 & -17.32 \\
\hline 54. Oman & 5.51 & -16.64 & 1.91 & 62.82 & -12.88 & -61.60 & -12.31 & 25.88 & 4.85 & -53.51 & 56.45 & -24.45 \\
\hline 55. Argentina & 25.05 & -33.01 & 30.44 & -25.73 & 30.72 & -81.41 & 35.63 & -24.52 & 42.10 & -64.50 & 61.92 & -4.58 \\
\hline 56. Serbia & 47.39 & -12.99 & 75.97 & -45.94 & 54.37 & -84.39 & 80.76 & -39.72 & 15.86 & -118.46 & 50.53 & -13.36 \\
\hline 57. Saudi Arabia & 16.20 & -26.31 & 1.30 & 39.02 & -15.96 & -65.68 & -3.07 & 68.18 & 41.41 & -35.44 & 77.58 & -12.50 \\
\hline 58. Chile & 20.94 & -26.51 & 31.73 & -27.35 & 30.85 & -58.42 & 40.56 & 41.81 & 15.80 & -54.57 & 35.45 & -4.03 \\
\hline 59. Uruguay & 1 & -19.61 & 29 & 6 & 18 & -6 & 46.71 & -1.28 & 51 & 2 & .77 & -3.69 \\
\hline 60. Bosnia & 34.95 & -13.48 & 72.87 & -71.83 & 22.76 & -69.14 & 28 & -3.44 & 12.27 & -126.05 & 37.33 & -15.85 \\
\hline 61. Macedonia & 34.10 & -19.66 & 57.59 & -67.25 & 38.34 & -10 & 7 & 52.19 & 28.57 & -12 & 30.05 & -16.82 \\
\hline 62. Ukraine & 39.00 & -2.19 & 82.46 & -117.16 & 66.48 & -88 & 0 & 57.93 & 34.89 & -15 & 66.07 & 22.33 \\
\hline 63. South Africa & 25.78 & 6.57 & 26.25 & -39.10 & 32.00 & -55.33 & 44.80 & 33.18 & 28.29 & -76.71 & 50.71 & 0.94 \\
\hline 64. Malaysia & 33.87 & 70.30 & 12.67 & 21.98 & 18.55 & -111.41 & 19.85 & 10.68 & -3.52 & -129.10 & 39.67 & -5.77 \\
\hline 65. Turkey & 30.98 & 20.50 & 30.75 & -55.43 & 9.29 & -54.89 & 74.00 & 37.83 & 15.34 & -109.71 & 41.55 & -13.58 \\
\hline 66. Montenegro & 40.27 & -26.85 & 80.99 & -35.16 & 33.02 & -98.26 & 72.04 & -15.09 & 16.07 & -132.97 & 47.22 & -23.93 \\
\hline 67. Brazil & 16.33 & -53.92 & 44.63 & 3.39 & 25.10 & -69.91 & 55.74 & 9.55 & 36.89 & -62.88 & 14.73 & -5.01 \\
\hline 68. Venezuela & 41.00 & -44.31 & 62.35 & -54.43 & 38.00 & -69.86 & 19.00 & -4.73 & 39.39 & -70.03 & 35.53 & -7.02 \\
\hline 69. Thailand & 40.14 & 42.43 & 22.63 & -40.32 & 36.92 & -111.67 & 39.49 & 25.78 & 15.46 & -134.97 & 33.23 & 3.66 \\
\hline 70. Albania & 34. & -6.44 & 57 & -38 & 82 & -141 & 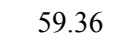 & 88 & 8.65 & -168.21 & 32 & -29.61 \\
\hline 71. Colombia & 42 & -9.12 & 38 & -44.36 & 20.57 & -00 & 34.51 & 12.68 & 39 & -73 & 10.52 & 4.25 \\
\hline 72. Ecuador & 28.05 & -19.21 & 27.50 & -18.48 & 8.44 & -102.25 & 26.80 & 4.61 & 42.12 & -78.93 & 35.81 & -9.48 \\
\hline 73. Jordan & 19.87 & -4.44 & 5.33 & 57.98 & 14.07 & -90.38 & -7.72 & -1.22 & 21.64 & -99.89 & 91.97 & 0.57 \\
\hline 74. Tunisia & 30.73 & 19.21 & 70.80 & -70.47 & -8.61 & -82.57 & 51.88 & 13.12 & 46.33 & -86.99 & -1.09 & -3.84 \\
\hline 75. Peru & 30.90 & -1.97 & 17.36 & -49.58 & 19.76 & -69.24 & 28.27 & 13.76 & 24.18 & -73.44 & 34.74 & -16.54 \\
\hline 76. Egypt & 40.52 & 30.45 & 21.53 & -25.98 & -0.98 & -148.38 & -5.06 & 80.25 & 31.82 & -167.08 & 75.21 & -17.63 \\
\hline 77. Moldova & 48.88 & -16.72 & 97.92 & -89.53 & 72.62 & -108.60 & 26 & 50.15 & 31.37 & -195.15 & 59.09 & 7.68 \\
\hline 78. Maldives & 37.85 & 4.69 & 17.86 & 95.92 & 19.95 & -147.47 & 53.57 & -12.73 & 5.92 & -188.82 & 52.18 & -10.07 \\
\hline 79. Gabon & 63.32 & -14.51 & 40.47 & -52.31 & 27.31 & -105.92 & 49.01 & 70.21 & 51.86 & -163.29 & 48.01 & -38.03 \\
\hline 80. Fiji & 14.08 & 12.00 & -25.43 & 47.23 & -0.36 & -133.77 & 29.28 & -49.89 & -2.21 & -143.47 & 51.25 & -23.53 \\
\hline 81. Georgia & 40.60 & -179.62 & 176.39 & -216.17 & 64.62 & -155.82 & -120.73 & -44.07 & 22.30 & -41.66 & -230.98 & 84.03 \\
\hline 82. Botswana & 57.49 & 8.76 & 30.23 & -57.82 & 40.14 & -50.80 & 55.89 & 25.58 & 57.92 & -110.75 & 52.69 & -17.50 \\
\hline 83. Namibia & 47.57 & -19.23 & 31.39 & -23.95 & 8.89 & -84.95 & 46.79 & 50.62 & 45.06 & -89.11 & 77.17 & -5.35 \\
\hline 84. Swaziland & 36.83 & 17.36 & 56.14 & -22.70 & 12.67 & -172.73 & 46.03 & 54.73 & 45.64 & -107.77 & 36.01 & -33.59 \\
\hline 85. Syria & 23.36 & -2.46 & 29.31 & 24.42 & 9.93 & -113.94 & 18.80 & 28.75 & 1.78 & -160.02 & 62.58 & -29.38 \\
\hline 86. Bolivia & 41.83 & 11.04 & 57.19 & -40.75 & 26.07 & -95.81 & 39.06 & 38.25 & 52.28 & -134.31 & 46.69 & 10.35 \\
\hline 87. Eq. Guinea & 48.69 & -52.32 & 53.22 & -64.23 & 6.42 & -128.00 & 37.54 & 81.54 & 43.87 & -209.60 & 20.27 & -35.60 \\
\hline 88. Paraguay & 15.23 & -22.33 & 48.34 & -66.36 & 17.25 & -88.40 & 54.76 & -16.21 & 44.47 & -122.28 & 35.66 & -2.35 \\
\hline 89. Cape Verde & 33.17 & -0.37 & 46.12 & 1.09 & 21.77 & -107.06 & 32.44 & 20.43 & 33.02 & -103.46 & 40.50 & -31.47 \\
\hline 90. Bhutan & 48.02 & 34.42 & 33.22 & -9.27 & 49.75 & -127.62 & 70.22 & 47.23 & 36.67 & -134.14 & 70.47 & 9.13 \\
\hline
\end{tabular}




\begin{tabular}{|c|c|c|c|c|c|c|c|c|c|c|c|c|}
\hline Country & $\begin{array}{l}\overrightarrow{8} \\
8 \\
\end{array}$ & $\begin{array}{ll}0 & 0 \\
0 & 0 \\
0 & 0 \\
0 & \tilde{0} \\
0 & 0 \\
0 & 0 \\
& 0 \\
\end{array}$ & 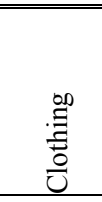 & 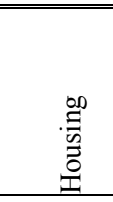 & 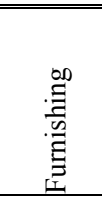 & 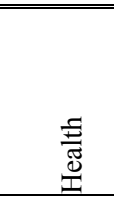 & 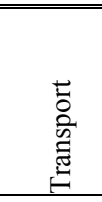 & 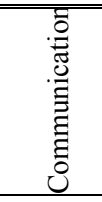 & 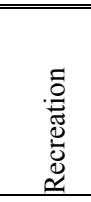 & 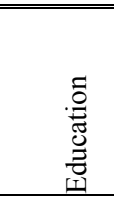 & 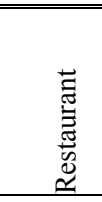 & 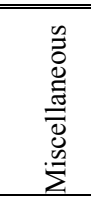 \\
\hline 91. Kyrgyzstan & 40.11 & -3.58 & 86.33 & -168.06 & 66.42 & -151.98 & 54.43 & 56.91 & 17.92 & -225.39 & 34.79 & -18.97 \\
\hline 92. Sri Lanka & 26.31 & 57.26 & -26.79 & -78.80 & 15.12 & -161.05 & 36.66 & 16.79 & 6.80 & -189.32 & 37.30 & -10.28 \\
\hline 93. Iraq & 46.94 & 34.22 & 24.26 & 47.88 & -10.82 & -107.95 & 14.28 & 63.33 & 54.69 & -110.47 & 98.75 & -5.11 \\
\hline 94. Mongolia & 42.40 & 25.09 & 31.45 & 19.06 & 38.56 & -167.21 & 52.58 & 25.57 & 26.11 & -198.46 & 82.05 & 19.05 \\
\hline 95. Philippines & 33.74 & -39.36 & 15.83 & -6.26 & 7.25 & -96.79 & 36.58 & 36.69 & 11.07 & -152.44 & 25.14 & -9.33 \\
\hline 96. Indonesia & 27.48 & 41.65 & -13.59 & 1 & 1.42 & -90.96 & 11 & 44.94 & -7.26 & -181.74 & 13.71 & -22.39 \\
\hline 97. Pakistan & 45.27 & 37.98 & 8.93 & -56.09 & 19.28 & -142.78 & 48.29 & -12.52 & 8.09 & -185.51 & 62.12 & -1.34 \\
\hline 98. Morocco & 27.12 & 55.93 & 29.97 & -73.58 & -19.19 & -53.78 & 37.21 & 30.61 & 18.85 & -53.74 & 42.54 & -9.69 \\
\hline 99. Lesotho & 56.36 & 10.06 & 35.61 & -80.09 & 20.32 & -138.77 & 66.62 & 91.52 & 77.48 & -128.76 & 48.30 & 3.64 \\
\hline 100. China & 42.89 & 47.00 & 64.69 & -6.57 & 38.26 & -165.74 & 50.90 & -13.55 & -3.57 & -126.01 & 63.48 & 13.93 \\
\hline 101. Vietnam & 47.12 & 23.18 & 27.36 & 3.03 & 44.14 & -154.84 & 100.10 & 21.55 & 13.62 & -219.69 & 44.85 & 15.05 \\
\hline 102. India & 28.73 & 68.71 & 5.27 & -25.18 & 36.01 & -166.55 & 71.64 & 9.63 & 14.95 & -169.83 & 52.94 & 1.35 \\
\hline 103. Cambodia & 39.88 & -0.36 & 18.12 & 9.62 & 13.88 & -170.50 & 47.34 & 49.81 & 1.00 & -226.94 & 47.71 & 4.85 \\
\hline 104. Yemen & 30.41 & -33.13 & 3.01 & 3.00 & 17.72 & -140.07 & 11.72 & 81.10 & 33.18 & -173.81 & 80.60 & -4.27 \\
\hline 105. Sudan & 31.91 & 56.11 & -29.87 & -70.94 & -36.69 & -103.30 & 20.61 & 44.70 & -10.09 & -133.05 & -10.66 & -65.60 \\
\hline 106. Laos & 4 & 23.31 & 37 & -7 & 79 & -18 & & 45.24 & 1.72 & -228.98 & 01 & 1.53 \\
\hline 107. Djibouti & 57.77 & -35.81 & 4 & & & & & 41.14 & 23.65 & & 57 & -61.46 \\
\hline 108. Kenya & & 18.71 & 1.76 & -96.87 & -10.52 & -115.84 & 70.80 & 102.60 & 51.98 & -103.84 & 3.42 & -33.65 \\
\hline 109. Sao Tome. & 35.41 & -13.02 & 35.32 & -90.18 & -11.99 & -115.41 & 29.32 & 49.81 & 33.74 & -183.00 & 23.03 & -34.97 \\
\hline 110. Congo, Rep. & 56.89 & 0.37 & 39.33 & -76.07 & 3.20 & -106.57 & 57.74 & 81.30 & 42.27 & -202.18 & 25.08 & -39.36 \\
\hline 111. Cameroon & 31.10 & -14.82 & 12.47 & -88.34 & -11.16 & -107.80 & 25.69 & 79.72 & 37.53 & -167.93 & 23.18 & -35.41 \\
\hline 112. Nigeria & 55.14 & -17.05 & -15.06 & -108.26 & -45.55 & -135.69 & 9.02 & 42.48 & 7.44 & -206.72 & 20.78 & -67.71 \\
\hline 113. Senegal & 43.38 & -19.92 & 4.97 & -88.35 & -19.19 & -106.70 & 40.46 & 8.39 & 9.48 & -131.87 & 32.25 & -29.54 \\
\hline 114. Chad & 27.12 & -17.06 & -28.78 & -213.14 & -12.97 & -242.25 & 20.95 & 55.35 & 1.08 & -416.35 & 8.33 & -57.77 \\
\hline 115. Nepal & 27.64 & 51.18 & 8.42 & -1.02 & 19.41 & -152.23 & & 26.00 & 5.84 & -167.72 & 55.31 & 1.92 \\
\hline 116. Bangladesh & 25.33 & -12.38 & 13.77 & -13.65 & 6.45 & -140.85 & 65.23 & 14.42 & 16.73 & -172.63 & 49.46 & -2.00 \\
\hline 117. Benin & 43.71 & -12.46 & 2.09 & -118.58 & -10.62 & -128.03 & 33.11 & 92.40 & 20.16 & -165.54 & 28.10 & -37.29 \\
\hline 118. Ghana & 58.24 & -1.45 & -3.21 & -145.26 & -9.38 & -126.82 & 42.31 & 53.43 & 25.23 & -145.80 & 44.52 & -67.78 \\
\hline 119. Cote d'Ivoire & 32.18 & -16.69 & -4.11 & -99.04 & -19.84 & -90.92 & 45.15 & 66.36 & 34.51 & -122.78 & 10.65 & -34.23 \\
\hline 120. Sierra Leone & 75.89 & 0.40 & 8.27 & -126.84 & 12.98 & -118.22 & 66.40 & 113.15 & 41.62 & -140.87 & 54.78 & -10.63 \\
\hline 121. Madagascar & 46.98 & 35.68 & 1.32 & -75.45 & -3.14 & -103.93 & 63.30 & 44.41 & 26.86 & -251.04 & 14.42 & -28.20 \\
\hline 122. Togo & 34.51 & -40.75 & 8.46 & -153.34 & -20.15 & -77.10 & 34.72 & 81.12 & 14.30 & -213.22 & 11.09 & -50.15 \\
\hline 123. Burkina Faso & 34.28 & -4.81 & -25.47 & -100.23 & -1.98 & -113.77 & 73.46 & 81.55 & 32.74 & -167.39 & 26.17 & -40.00 \\
\hline 124. Guinea & 67.36 & -75.05 & -1.82 & -100.74 & -46.15 & -77.45 & 64.86 & 58.36 & 1.14 & -188.05 & 11.03 & -34.33 \\
\hline 125. Mali & 41.95 & -45.95 & -3.83 & -79.18 & -7.32 & -108.53 & 43.23 & 60.31 & 29.95 & -158.17 & 12.71 & -24.40 \\
\hline 126. Angola & 53.81 & -30.09 & 27.74 & -109.76 & -1.02 & -87.95 & 44.69 & 57.30 & 41.54 & -138.28 & 47.78 & -35.12 \\
\hline 127. Rwanda & 31.69 & 4.63 & 46.51 & -34.58 & 26.97 & -126.89 & 68.02 & 72.18 & 54.74 & -182.90 & 26.80 & -13.80 \\
\hline 128. CAR & 35.80 & -26.59 & -7.86 & -173.75 & -28.14 & -110.17 & 56.28 & 49.02 & 11.64 & -189.50 & 0.59 & -45.98 \\
\hline 129. Mozambique & 31.58 & 6.15 & 20.22 & -128.90 & -0.82 & -99.59 & 67.09 & 71.94 & 33.59 & -133.37 & 39.69 & -21.99 \\
\hline 130. Niger & 36.77 & -14.28 & -25.65 & -109.86 & -12.33 & -108.34 & 49.17 & 62.30 & 28.90 & -151.68 & 20.92 & -46.66 \\
\hline 131. Guinea-Biss. & 30.64 & -27.05 & 24.54 & -102.19 & -2.83 & -130.62 & 46.86 & 122.50 & 32.60 & -216.19 & 18.79 & -37.05 \\
\hline 132. Congo, D.R. & 36.46 & -21.36 & -24.58 & -86.92 & -26.34 & -131.51 & 49.21 & 68.73 & 12.77 & -186.20 & 16.18 & -66.76 \\
\hline Mean--All & 31.31 & -0.22 & 26.65 & -36.76 & 13.64 & -90.87 & 42.20 & 23.82 & 19.74 & -115.13 & 36.14 & -11.43 \\
\hline --Rich & 19.19 & 9.50 & 16.20 & -10.33 & 11.25 & -48.14 & 39.28 & -9.64 & 7.40 & -49.80 & 30.29 & -1.28 \\
\hline --Poor & 35.55 & -3.36 & 30.30 & -45.68 & 14.56 & -105.60 & 43.57 & 34.87 & 23.92 & -137.41 & 38.39 & -14.83 \\
\hline
\end{tabular}

Notes: 1 . The elements in this table are the logarithmic relative price of good $\mathrm{i}$ in country $\mathrm{c},\left(\log \mathrm{p}_{\mathrm{i}}^{\mathrm{c}}-\log \mathrm{P}^{\mathrm{c}}\right) \times 100$. 2. Means exclude US. 
TABLE A3

IMPLIED PRICE DISPERSION AND INCOME, WITH AND WITHOUT OUTLIERS

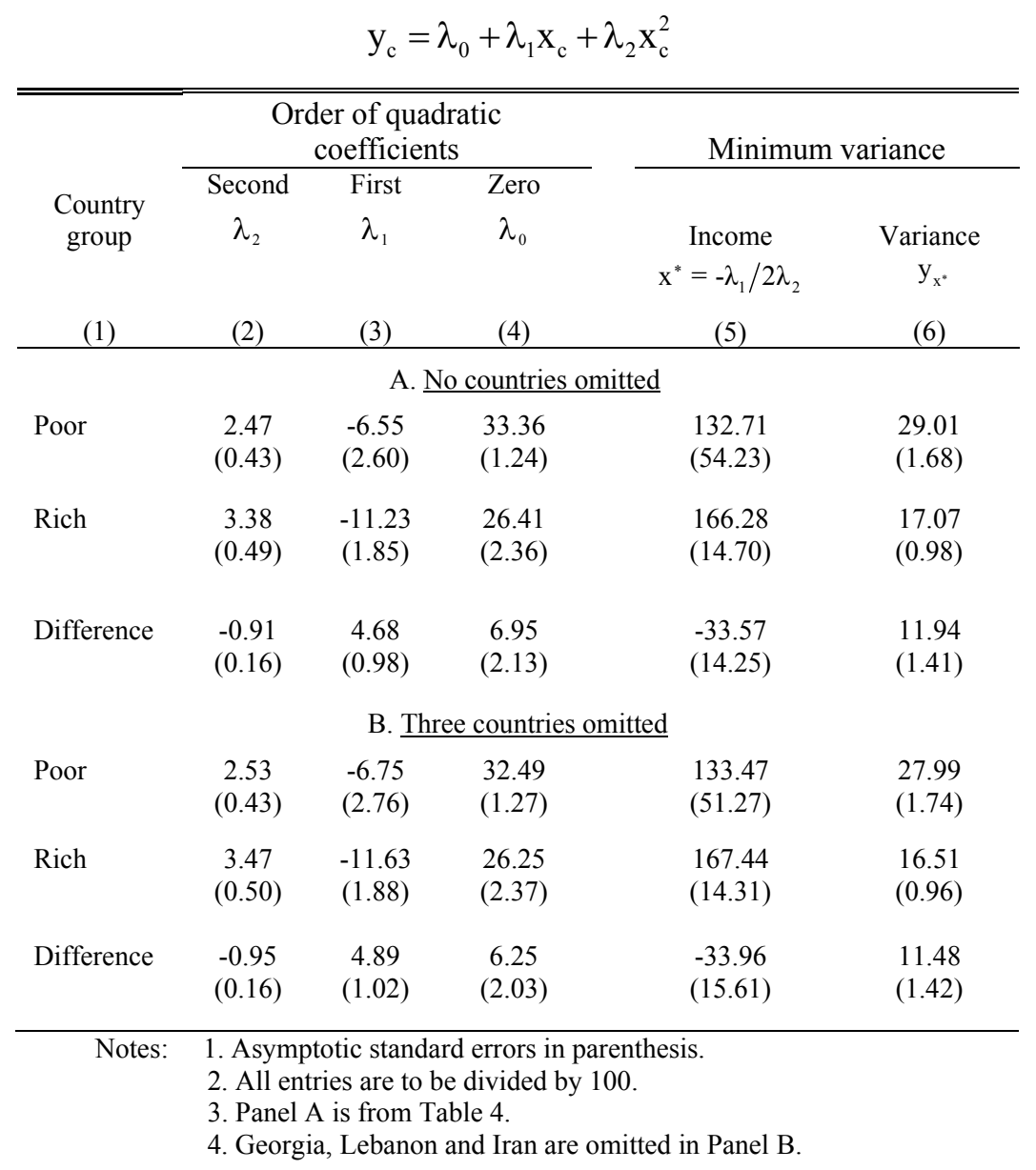


TABLE A4

RELATIVE PRICES AND INCOMES, RICH AND POOR COUNTRIES SEPERATED, 132 COUNTRIES IN 2005

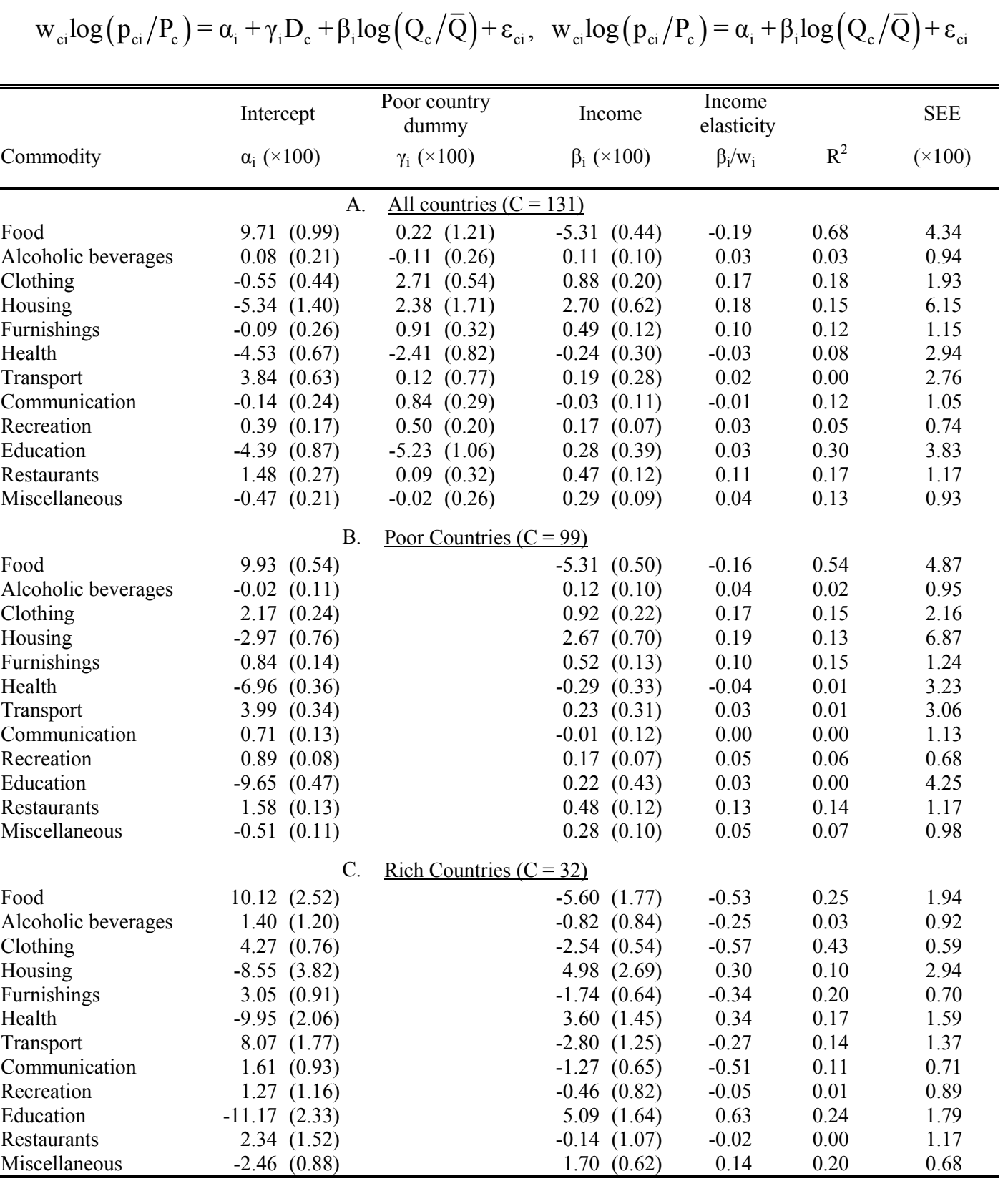

Notes: 1. Standard errors in parentheses.

2. All regressions exclude US, the base country.

3. Elasticities in the third last column are evaluated at means.

4. Panel A reproduces Table 2. 
TABLE A5

\section{WALD TESTS OF EQUALITY OF COEFFICIENTS ACROSS COUNTRY GROUPS}

\begin{tabular}{lcr}
\hline \hline Commodity & Intercepts & \multicolumn{1}{c}{ Slopes } \\
\hline \multicolumn{4}{c}{ A. Individual commodities. } \\
Food & $0.01(0.94)$ & $0.03(0.87)$ \\
Alcoholic beverages & $1.39(0.24)$ & $1.25(0.26)$ \\
Clothing & $6.88(0.01)$ & $35.75(0.00)$ \\
Housing & $2.05(0.15)$ & $0.69(0.41)$ \\
Furnishings & $5.76(0.02)$ & $11.89(0.00)$ \\
Health & $2.05(0.03)$ & $6.89(0.01)$ \\
Transport & $5.12(0.02)$ & $5.56(0.02)$ \\
Communication & $0.93(0.34)$ & $3.61(0.01)$ \\
Recreation & $0.11(0.74)$ & $0.60(0.44)$ \\
Education & $0.41(0.52)$ & $8.27(0.00)$ \\
Restaurants & $0.25(0.62)$ & $0.33(0.56)$ \\
Miscellaneous & $4.85(0.03)$ & $5.17(0.02)$ \\
& B. All commodities & \\
& $29.77(0.00)$ & $80.05(0.00)$ \\
\hline \multicolumn{1}{c}{ Note: } & The test statistics in panel A (B) follow a $\chi^{2}$ \\
& distribution $\begin{array}{l}\text { with one (twelve) degrees of } \\
\text { freedom. P-values are in parenthesis. }\end{array}$
\end{tabular}


TABLE A6

IMPLIED PRICE DISPERSION AND INCOME, RICH AND POOR COUNTRIES SEPERATED

\begin{tabular}{|c|c|c|c|c|c|c|c|}
\hline \multirow[b]{3}{*}{$\begin{array}{l}\text { Country } \\
\text { group } \\
\text { (1) }\end{array}$} & \multicolumn{5}{|c|}{$\mathrm{y}_{\mathrm{c}}=\lambda_{0}+\lambda_{1} \mathrm{x}_{\mathrm{c}}+\lambda_{2} \mathrm{x}_{\mathrm{c}}^{2}$} & & \\
\hline & \multicolumn{3}{|c|}{$\begin{array}{c}\text { Order of quadratic } \\
\text { coefficients }\end{array}$} & \multicolumn{2}{|c|}{ Minimum variance } & \multicolumn{2}{|c|}{ Intersection } \\
\hline & $\begin{array}{c}\text { Second } \\
\lambda_{2} \\
(2) \\
\end{array}$ & $\begin{array}{c}\text { First } \\
\lambda_{1} \\
(3) \\
\end{array}$ & $\begin{array}{c}\text { Zero } \\
\lambda_{0} \\
(4) \\
\end{array}$ & $\begin{array}{c}\text { Income } \\
\mathrm{x}^{*}=-\lambda_{1} / 2 \lambda_{2} \\
(5)\end{array}$ & $\begin{array}{c}\text { Variance } \\
\mathrm{y}_{\mathrm{x}^{*}} \\
(6)\end{array}$ & Income & Variance \\
\hline \multicolumn{8}{|c|}{ A. All Countries Combined } \\
\hline Poor & $\begin{array}{c}2.47 \\
(0.43)\end{array}$ & $\begin{array}{l}-6.55 \\
(2.60)\end{array}$ & $\begin{array}{l}33.36 \\
(1.24)\end{array}$ & $\begin{array}{l}132.71 \\
(54.23)\end{array}$ & $\begin{array}{l}29.01 \\
(1.68)\end{array}$ & \multirow{2}{*}{$\begin{array}{l}-120.47 \\
(45.68)\end{array}$} & \multirow{3}{*}{$\begin{array}{l}44.83 \\
(3.10)\end{array}$} \\
\hline Rich & $\begin{array}{c}3.38 \\
(0.49)\end{array}$ & $\begin{array}{r}-11.23 \\
(1.85)\end{array}$ & $\begin{array}{l}26.41 \\
(2.36)\end{array}$ & $\begin{array}{l}166.28 \\
(14.70)\end{array}$ & $\begin{array}{l}17.07 \\
(0.98)\end{array}$ & & \\
\hline Difference & $\begin{array}{l}-0.91 \\
(0.16)\end{array}$ & $\begin{array}{c}4.68 \\
(0.98)\end{array}$ & $\begin{array}{c}6.95 \\
(2.13)\end{array}$ & $\begin{array}{l}-33.57 \\
(14.25)\end{array}$ & $\begin{array}{l}11.94 \\
(1.41)\end{array}$ & \multirow{4}{*}{$\begin{array}{l}128.98 \\
(47.12)\end{array}$} & \\
\hline \multicolumn{8}{|c|}{ B. Rich \& Poor Separated } \\
\hline Poor & $\begin{array}{l}2.48 \\
(0.49)\end{array}$ & $\begin{array}{l}-6.26 \\
(3.17)\end{array}$ & $\begin{array}{l}16.38 \\
(0.64)\end{array}$ & $\begin{array}{l}126.54 \\
(65.25)\end{array}$ & $\begin{array}{l}12.41 \\
(0.71)\end{array}$ & & \multirow{3}{*}{$\begin{array}{l}12.41 \\
(0.62)\end{array}$} \\
\hline Rich & $\begin{array}{l}13.32 \\
(3.75)\end{array}$ & $\begin{array}{l}-52.91 \\
(12.80)\end{array}$ & $\begin{array}{c}58.50 \\
(10.79)\end{array}$ & $\begin{array}{l}198.62 \\
(10.31)\end{array}$ & $\begin{array}{c}5.96 \\
(0.90)\end{array}$ & & \\
\hline Difference & $\begin{array}{r}-10.84 \\
(3.52)\end{array}$ & $\begin{array}{l}46.64 \\
(11.98)\end{array}$ & $\begin{array}{l}-42.12 \\
(10.57)\end{array}$ & $\begin{array}{l}-72.08 \\
(25.74)\end{array}$ & $\begin{array}{c}6.45 \\
(0.47)\end{array}$ & & \\
\hline
\end{tabular}

Notes: 1. Asymptotic standard errors in parenthesis.

2. All entries are to be divided by 100 .

3. Panel A reproduces Table 4 and intersection values from Figure 3. 


\section{FIGURE A1}

\section{RELATIVE PRICES AND INCOMES RICH vs POOR COUNTRIES}

1. Food

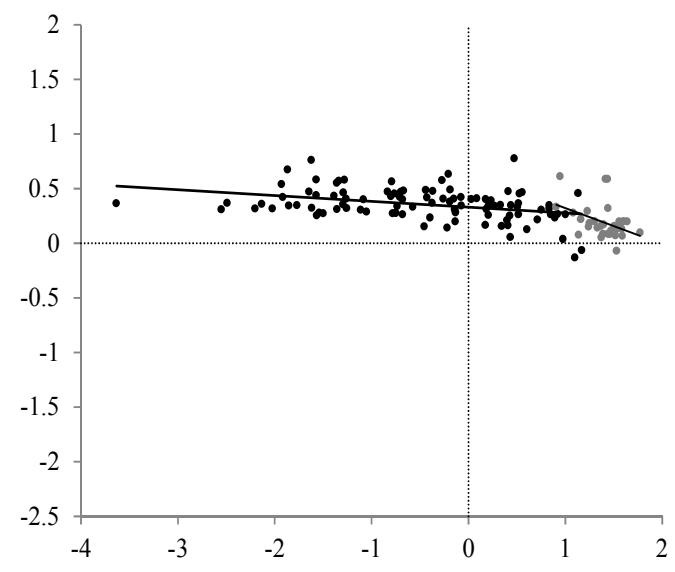

3. Clothing

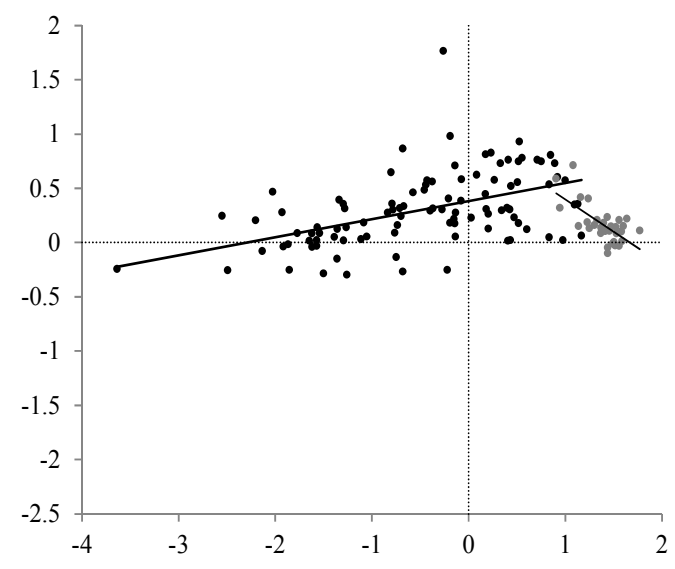

5. Furnishings

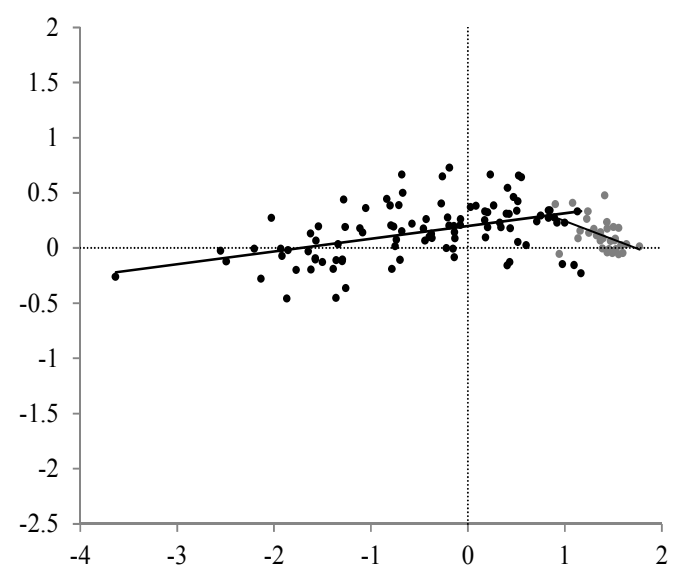

2. Alcoholic Beverages

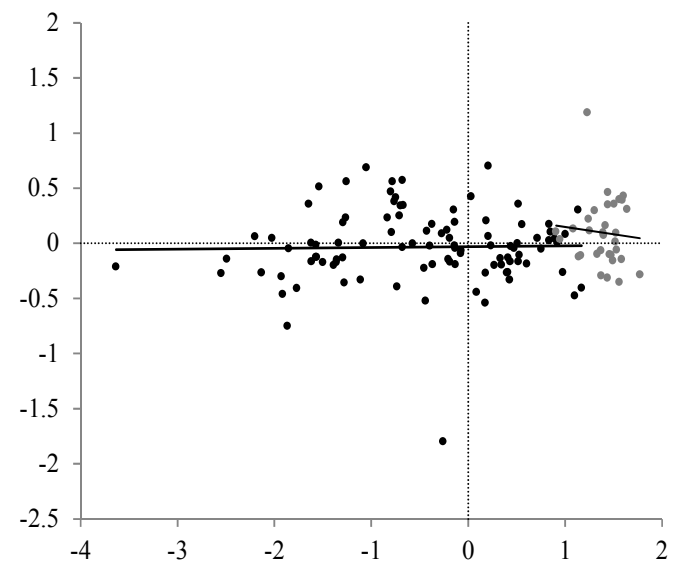

4. Housing

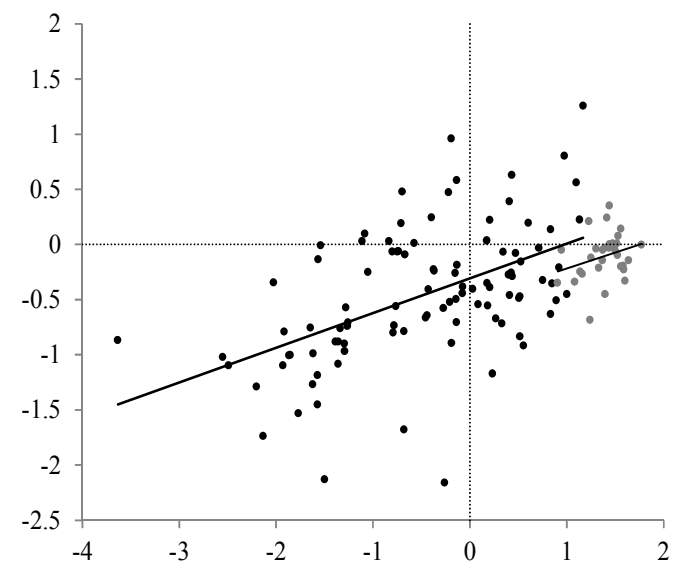

6. Health

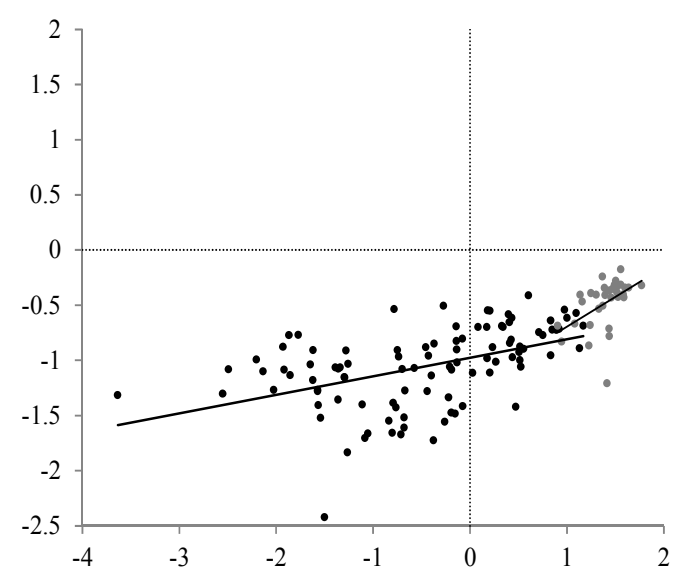

(Continued on next page) 
FIGURE A1 (continued)

\section{RELATIVE PRICES AND INCOMES RICH vs POOR COUNTRIES}

\section{Transport}
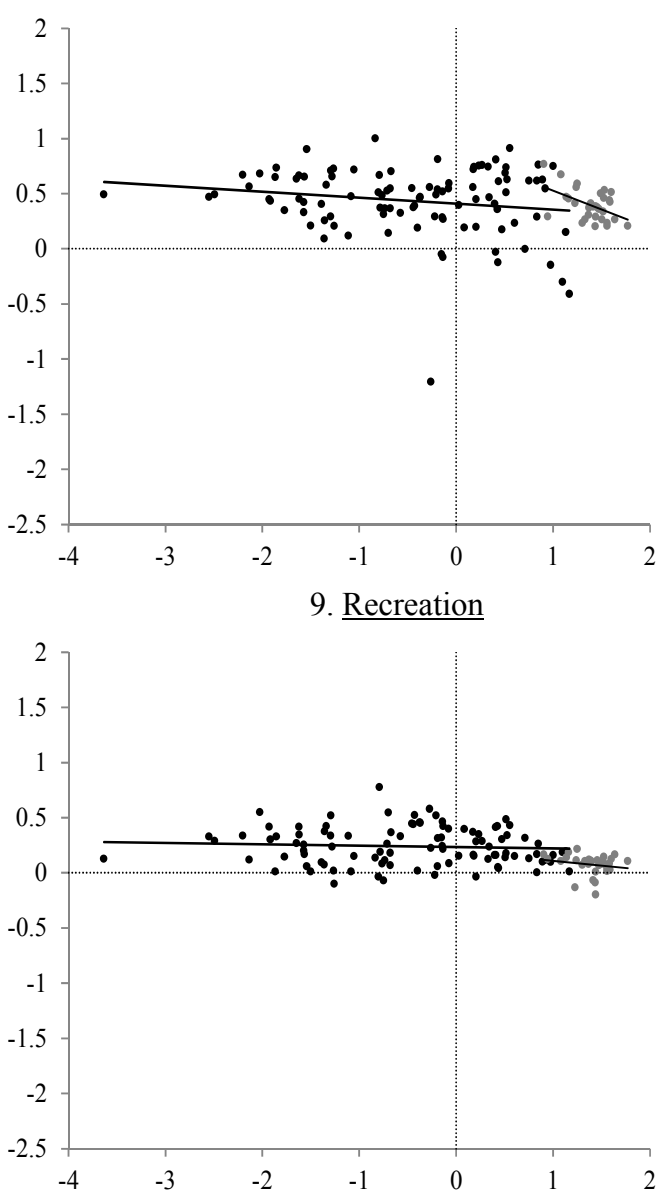

11. Restaurants

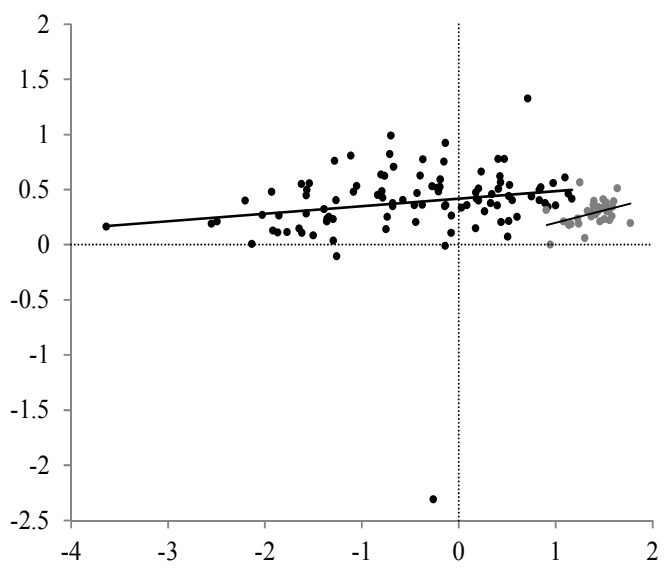

8. Communication
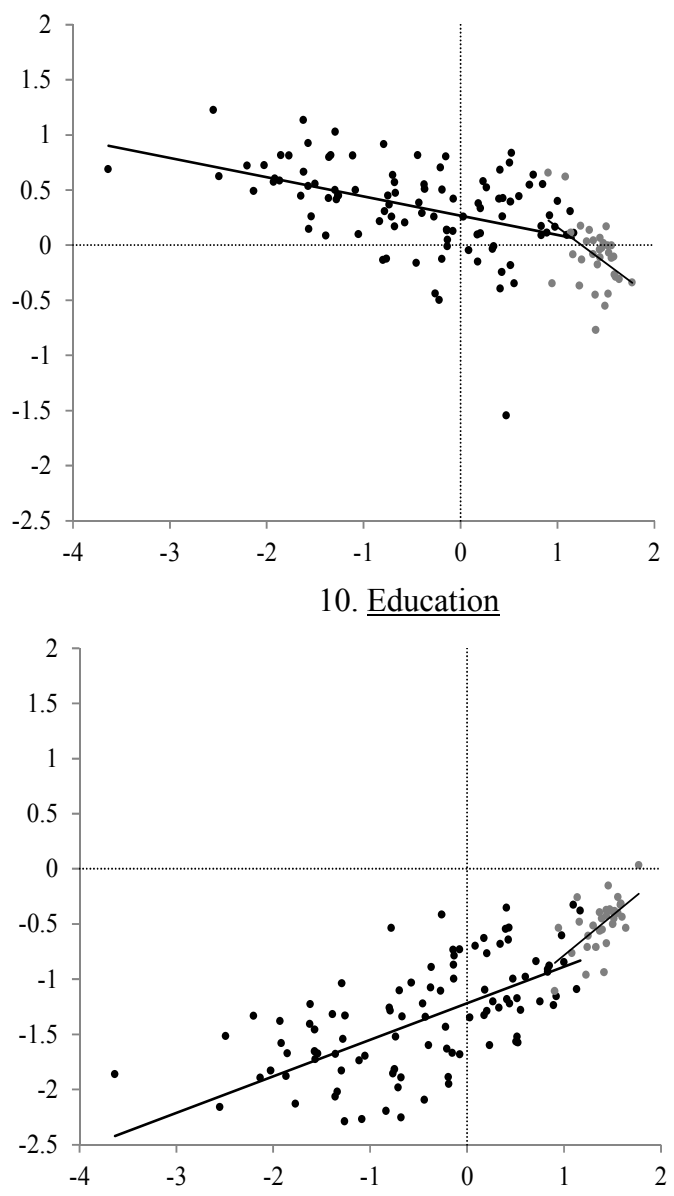

12. Miscellaneous

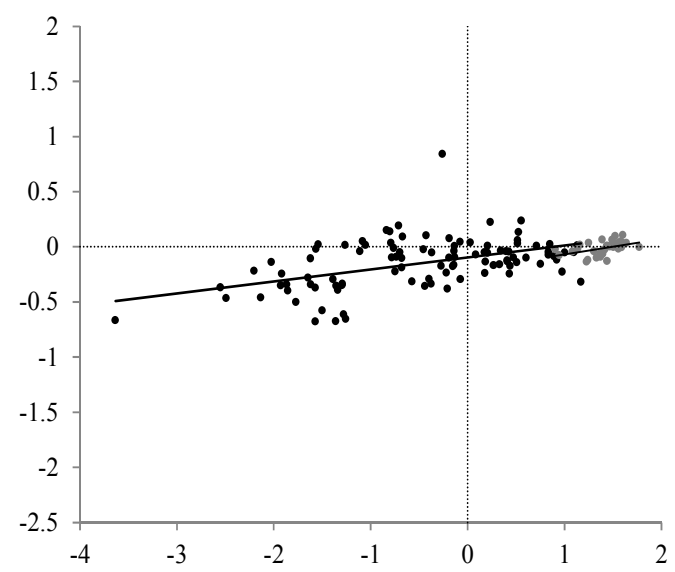

Notes: 1 . In panel $\mathrm{i}(\mathrm{i}=1, \ldots, 12)$, the $\mathrm{i}^{\text {th }}$ relative price, $\left(\log \mathrm{p}_{\mathrm{i}}^{\mathrm{c}}-\log \mathrm{P}^{\mathrm{c}}\right) \times 100$, is plotted against relative income per-capita, $\log \left(\mathrm{Q}^{\mathrm{c}} / \overline{\mathrm{Q}}\right) \times 100, \mathrm{c}=1, \ldots, 132$, where $\overline{\mathrm{Q}}$ is geometric mean income. The black solid line is the LS regression line for the poor countries, while the grey line refers to the rich..

2. As it is an outlier, country number 114, Chad, is excluded from "Education" plot, but is included in the regression line. 3. US, the base country, is excluded from all scatterplots. 


\section{FIGURE A3}

TWO VERSIONS OF

DISPERSION AND INCOME RELATION

A. All Countries Combined

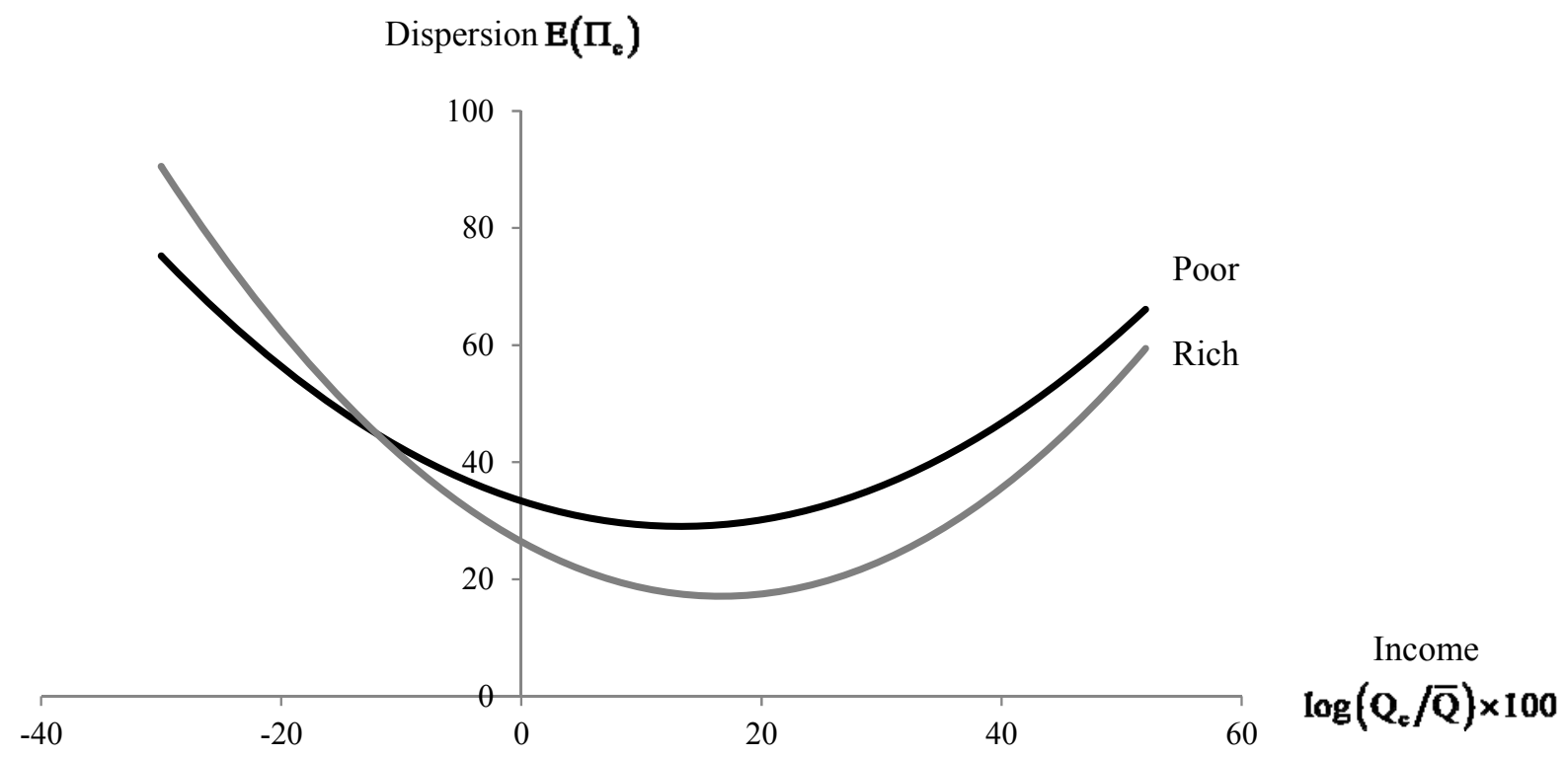

B. Rich and Poor Separated

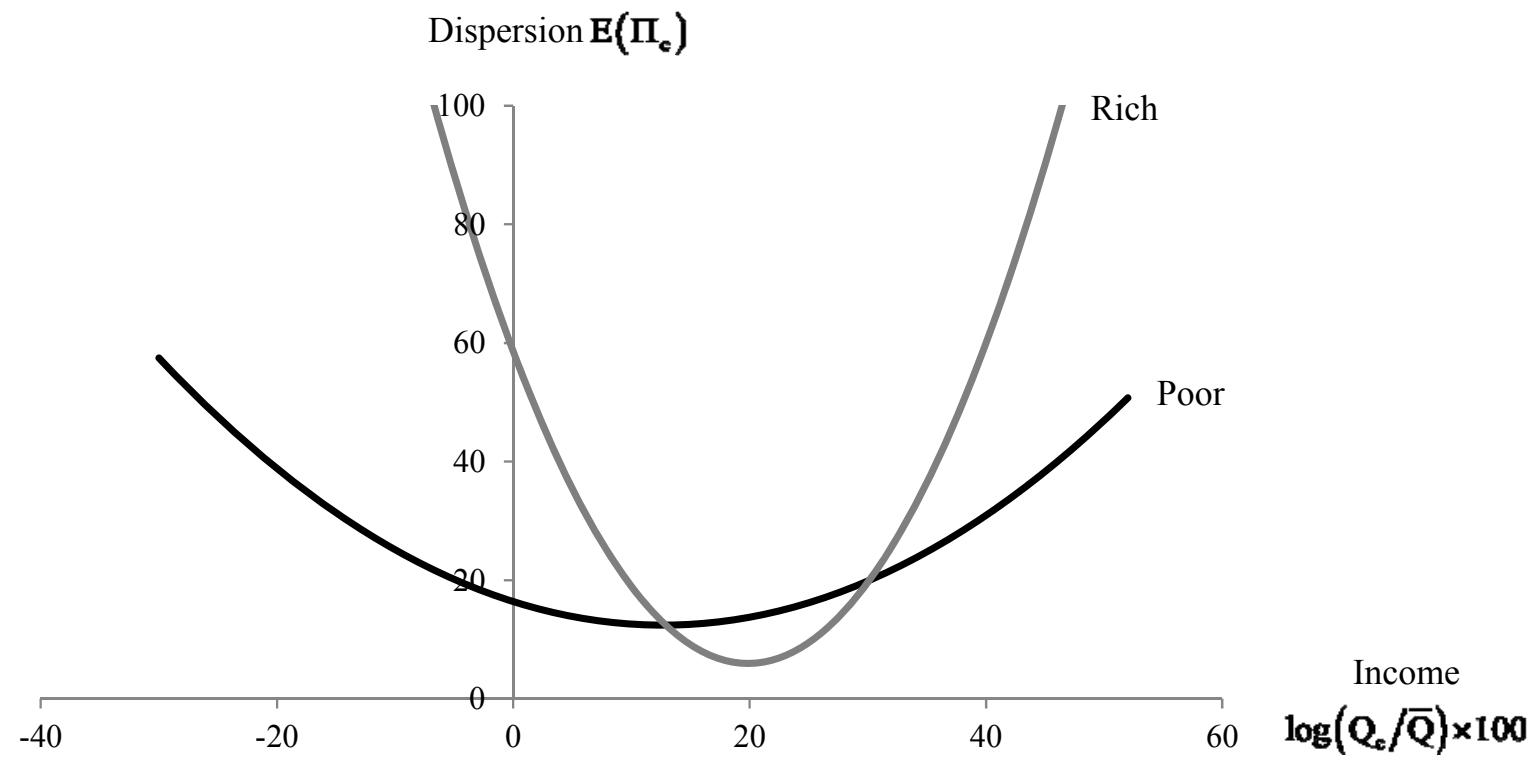

Note: Panel A is Figure 3 on a different scale. 
FIGURE A3

WEIGHTED RELATIVE PRICES AND INCOMES,

132 COUNTRIES IN 2005

1. Food

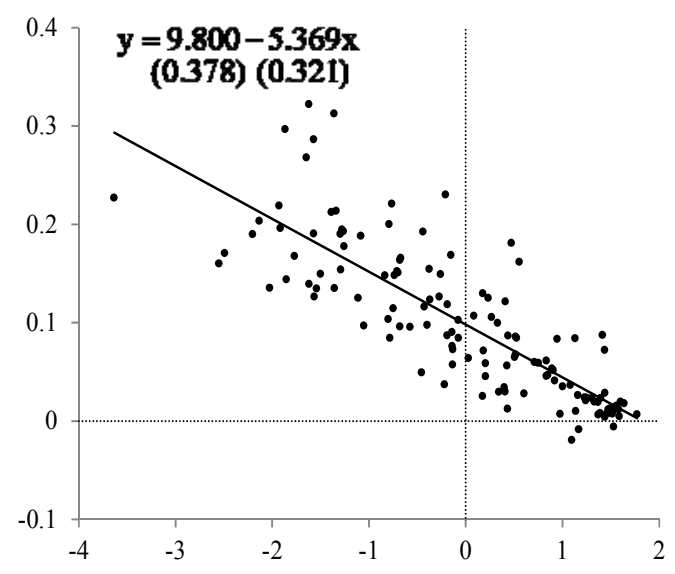

3. Clothing

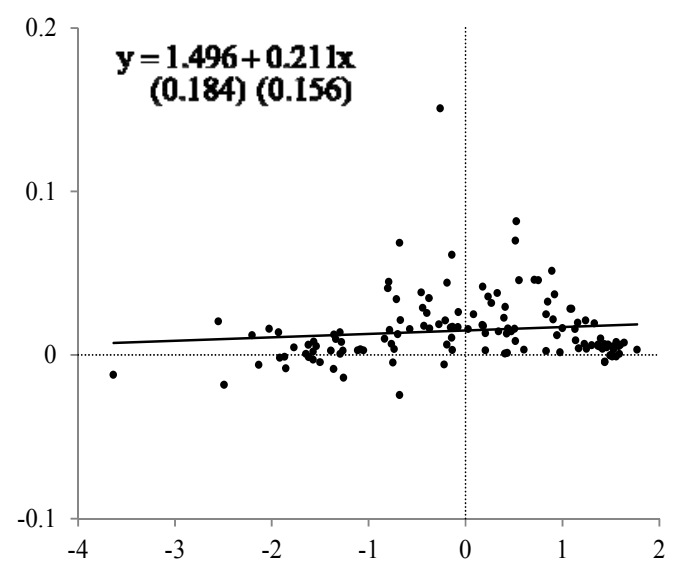

5. Furnishings

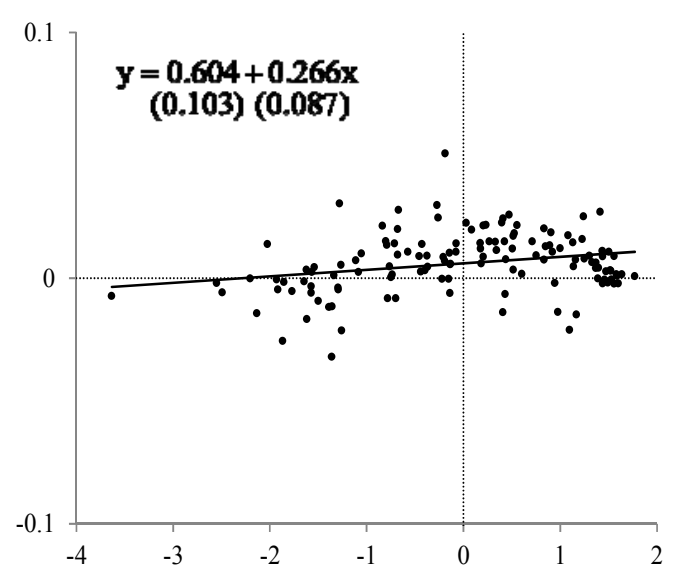

2. Alcoholic Beverages

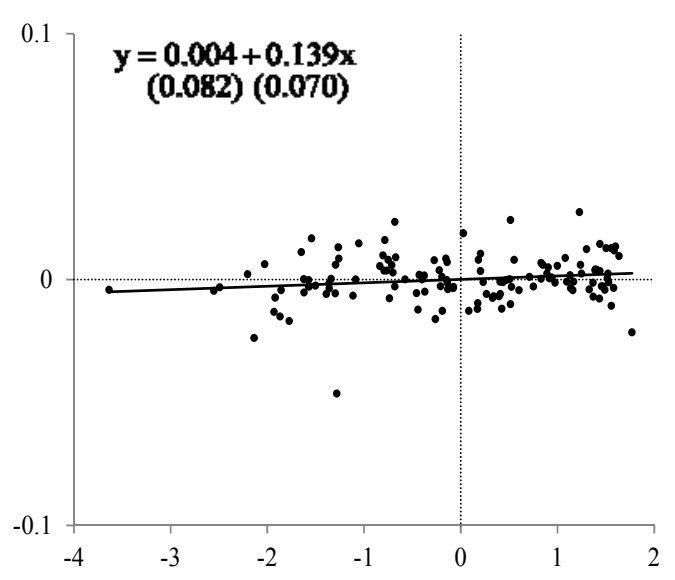

4. Housing

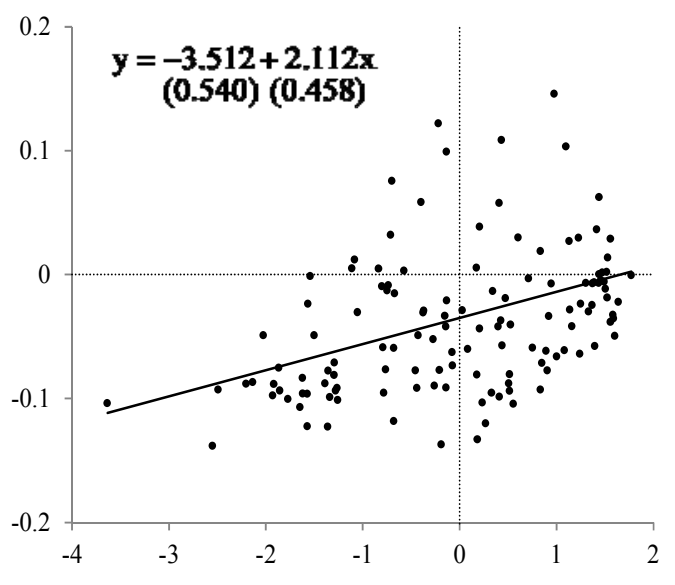

6. Health

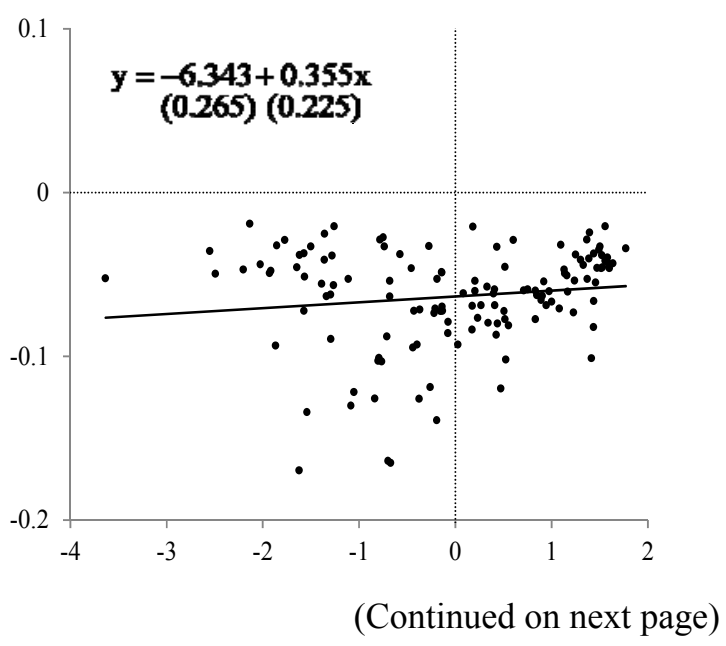


FIGURE A3 (continued)

\section{WEIGHTED RELATIVE PRICES AND INCOMES,}

\section{COUNTRIES IN 2005}

\section{Transport}

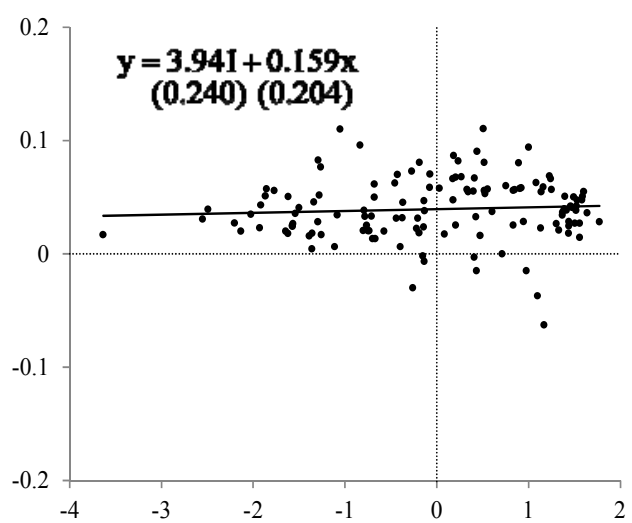

9. Recreation

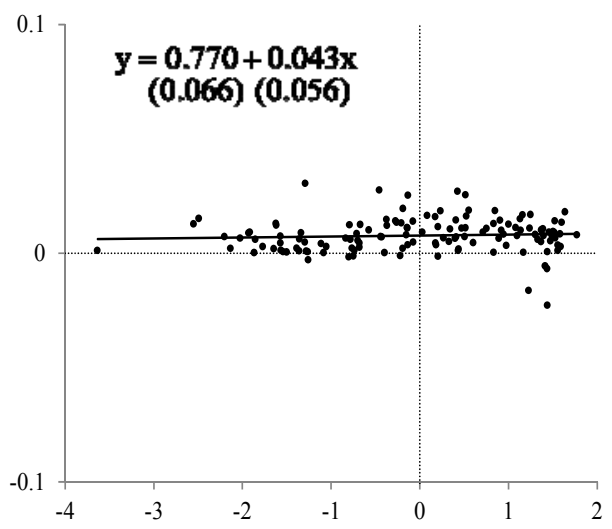

11. Restaurants

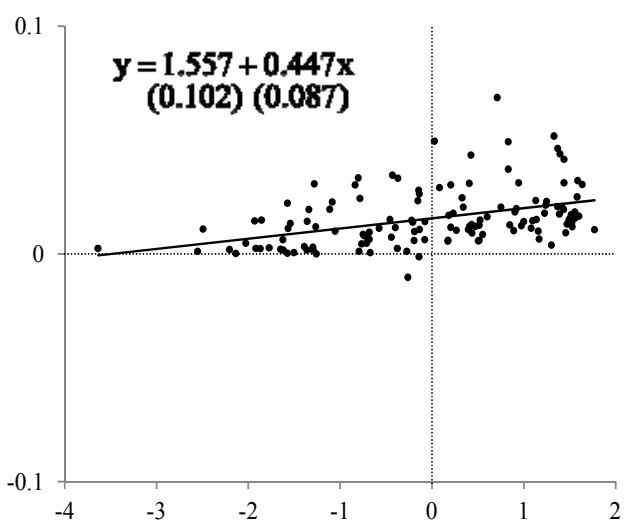

8. Communication

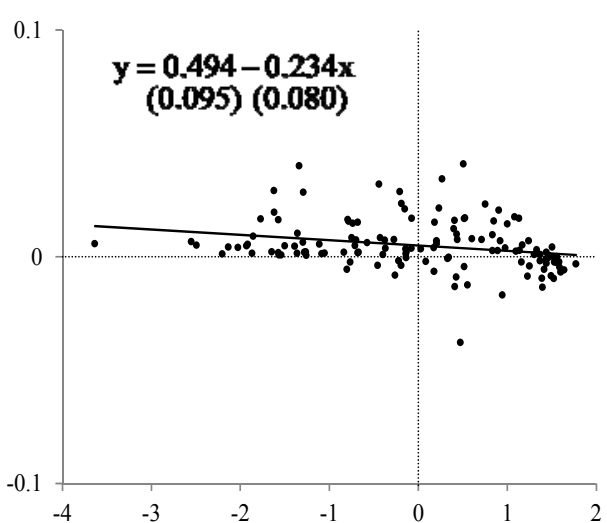

10. Education

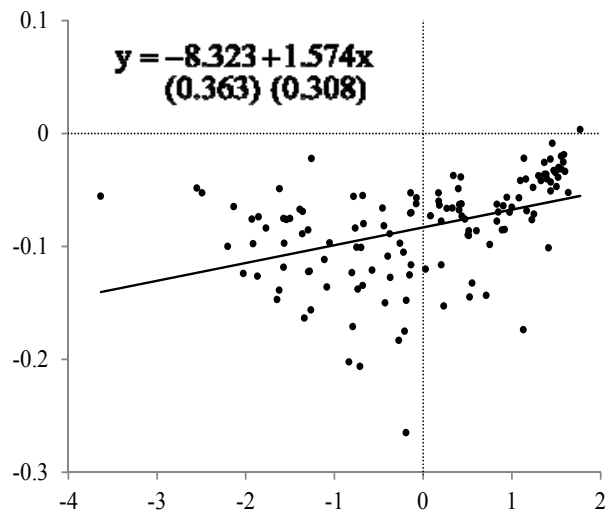

12. Miscellaneous

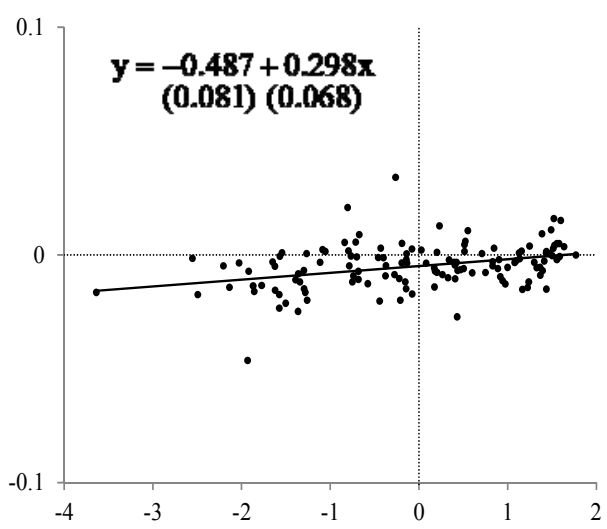

Notes: 1. In panel $\mathrm{i}(\mathrm{i}=1, \ldots, 12)$, the $\mathrm{i}^{\text {th }}$ relative price, weighted by the corresponding budget share, $\mathrm{w}_{\mathrm{i}}\left(\log \mathrm{p}_{\mathrm{i}}^{\mathrm{c}}-\log \mathrm{P}\right) \times 100$, is plotted against relative income per-capita, $\log \left(\mathrm{Q}^{\mathrm{c}} / \overline{\mathrm{Q}}\right) \times 100, \mathrm{c}=1, \ldots, 132$, where $\overline{\mathrm{Q}}$ is geometric mean income. The solid line is the LS regression line.

2. US, the base country, is excluded from all scatterplots.

3. All estimates and standard errors are to be divided by 100 . 
ECONOMICS DISCUSSION PAPERS

2010

\begin{tabular}{|c|c|c|}
\hline $\begin{array}{l}\text { DP } \\
\text { NUMBER }\end{array}$ & AUTHORS & TITLE \\
\hline 10.01 & Hendry, D.F. & $\begin{array}{l}\text { RESEARCH AND THE ACADEMIC: A TALE OF } \\
\text { TWO CULTURES }\end{array}$ \\
\hline 10.02 & McLure, M., Turkington, D. and Weber, E.J. & A CONVERSATION WITH ARNOLD ZELLNER \\
\hline 10.03 & $\begin{array}{l}\text { Butler, D.J., Burbank, V.K. and } \\
\text { Chisholm, J.S. }\end{array}$ & $\begin{array}{l}\text { THE FRAMES BEHIND THE GAMES: PLAYER'S } \\
\text { PERCEPTIONS OF PRISONER'S DILEMMA, } \\
\text { CHICKEN, DICTATOR, AND ULTIMATUM GAMES }\end{array}$ \\
\hline 10.04 & Harris, R.G., Robertson, P.E. and Xu, J.Y. & $\begin{array}{l}\text { THE INTERNATIONAL EFFECTS OF CHINA'S } \\
\text { GROWTH, TRADE AND EDUCATION BOOMS }\end{array}$ \\
\hline 10.05 & Clements, K.W., Mongey, S. and Si, J. & $\begin{array}{l}\text { THE DYNAMICS OF NEW RESOURCE PROJECTS } \\
\text { A PROGRESS REPORT }\end{array}$ \\
\hline 10.06 & Costello, G., Fraser, P. and Groenewold, N. & $\begin{array}{l}\text { HOUSE PRICES, NON-FUNDAMENTAL } \\
\text { COMPONENTS AND INTERSTATE SPILLOVERS: } \\
\text { THE AUSTRALIAN EXPERIENCE }\end{array}$ \\
\hline 10.07 & Clements, $\mathrm{K}$. & $\begin{array}{l}\text { REPORT OF THE } 2009 \text { PHD CONFERENCE IN } \\
\text { ECONOMICS AND BUSINESS }\end{array}$ \\
\hline 10.08 & Robertson, P.E. & $\begin{array}{l}\text { INVESTMENT LED GROWTH IN INDIA: HINDU } \\
\text { FACT OR MYTHOLOGY? }\end{array}$ \\
\hline 10.09 & Fu, D., Wu, Y. and Tang, Y. & $\begin{array}{l}\text { THE EFFECTS OF OWNERSHIP STRUCTURE AND } \\
\text { INDUSTRY CHARACTERISTICS ON EXPORT } \\
\text { PERFORMANCE }\end{array}$ \\
\hline 10.10 & Wu, Y. & $\begin{array}{l}\text { INNOVATION AND ECONOMIC GROWTH IN } \\
\text { CHINA }\end{array}$ \\
\hline 10.11 & Stephens, B.J. & $\begin{array}{l}\text { THE DETERMINANTS OF LABOUR FORCE } \\
\text { STATUS AMONG INDIGENOUS AUSTRALIANS }\end{array}$ \\
\hline 10.12 & Davies, $\mathrm{M}$. & $\begin{array}{l}\text { FINANCING THE BURRA BURRA MINES, SOUTH } \\
\text { AUSTRALIA: LIQUIDITY PROBLEMS AND } \\
\text { RESOLUTIONS }\end{array}$ \\
\hline 10.13 & Tyers, R. and Zhang, Y. & APPRECIATING THE RENMINBI \\
\hline 10.14 & Clements, K.W., Lan, Y. and Seah, S.P. & $\begin{array}{l}\text { THE BIG MAC INDEX TWO DECADES ON } \\
\text { AN EVALUATION OF BURGERNOMICS }\end{array}$ \\
\hline 10.15 & Robertson, P.E. and Xu, J.Y. & $\begin{array}{l}\text { IN CHINA'S WAKE: } \\
\text { HAS ASIA GAINED FROM CHINA'S GROWTH? }\end{array}$ \\
\hline 10.16 & Clements, K.W. and Izan, H.Y. & $\begin{array}{l}\text { THE PAY PARITY MATRIX: A TOOL FOR } \\
\text { ANALYSING THE STRUCTURE OF PAY }\end{array}$ \\
\hline 10.17 & Gao, G. & WORLD FOOD DEMAND \\
\hline 10.18 & $\mathrm{Wu}, \mathrm{Y}$. & $\begin{array}{l}\text { INDIGENOUS INNOVATION IN CHINA: } \\
\text { IMPLICATIONS FOR SUSTAINABLE GROWTH }\end{array}$ \\
\hline 10.19 & Robertson, P.E. & DECIPHERING THE HINDU GROWTH EPIC \\
\hline 10.20 & Stevens, G. & $\begin{array}{l}\text { RESERVE BANK OF AUSTRALIA-THE ROLE OF } \\
\text { FINANCE }\end{array}$ \\
\hline 10.21 & Widmer, P.K., Zweifel, P. and Farsi, M. & $\begin{array}{l}\text { ACCOUNTING FOR HETEROGENEITY IN THE } \\
\text { MEASUREMENT OF HOSPITAL PERFORMANCE }\end{array}$ \\
\hline
\end{tabular}




\begin{tabular}{|l|l|l|}
\hline 10.22 & McLure, $\mathrm{M}$. & $\begin{array}{l}\text { ASSESSMENTS OF A. C. PIGOU'S FELLOWSHIP } \\
\text { THESES }\end{array}$ \\
\hline 10.23 & Poon, A.R. & $\begin{array}{l}\text { THE ECONOMICS OF NONLINEAR PRICING: } \\
\text { EVIDENCE FROM AIRFARES AND GROCERY } \\
\text { PRICES }\end{array}$ \\
\hline 10.24 & Halperin, D. & $\begin{array}{l}\text { FORECASTING METALS RETURNS: A BAYESIAN } \\
\text { DECISION THEORETIC APPROACH }\end{array}$ \\
\hline 10.25 & Clements, K.W. and Si. J. & $\begin{array}{l}\text { THE INVESTMENT PROJECT PIPELINE: COST } \\
\text { ESCALATION, LEAD-TIME, SUCCESS, FAILURE } \\
\text { AND SPEED }\end{array}$ \\
\hline 10.26 & Chen, A., Groenewold, N. and Hagger, A.J. & $\begin{array}{l}\text { THE REGIONAL ECONOMIC EFFECTS OF A } \\
\text { REDUCTION IN CARBON EMISSIONS }\end{array}$ \\
\hline 10.27 & $\begin{array}{l}\text { Siddique, A., Selvanathan, E.A. and } \\
\text { Selvanathan, S. }\end{array}$ & $\begin{array}{l}\text { REMITTANCES AND ECONOMIC GROWTH: } \\
\text { EMPIRICAL EVIDENCE FROM BANGLADESH, } \\
\text { INDIA AND SRI LANKA }\end{array}$ \\
\hline
\end{tabular}




\section{ECONOMICS DISCUSSION PAPERS}

\section{1}

\begin{tabular}{|c|c|c|}
\hline $\begin{array}{l}\text { DP } \\
\text { NUMBER }\end{array}$ & AUTHORS & TITLE \\
\hline 11.01 & Robertson, P.E. & DEEP IMPACT: CHINA AND THE WORLD ECONOMY \\
\hline 11.02 & Kang, C. and Lee, S.H. & $\begin{array}{l}\text { BEING KNOWLEDGEABLE OR SOCIABLE? } \\
\text { DIFFERENCES IN RELATIVE IMPORTANCE OF } \\
\text { COGNITIVE AND NON-COGNITIVE SKILLS }\end{array}$ \\
\hline 11.03 & Turkington, D. & DIFFERENT CONCEPTS OF MATRIX CALCULUS \\
\hline 11.04 & Golley, J. and Tyers, R. & $\begin{array}{l}\text { CONTRASTING GIANTS: DEMOGRAPHIC CHANGE } \\
\text { AND ECONOMIC PERFORMANCE IN CHINA AND } \\
\text { INDIA }\end{array}$ \\
\hline 11.05 & Collins, J., Baer, B. and Weber, E.J. & $\begin{array}{l}\text { ECONOMIC GROWTH AND EVOLUTION: PARENTAL } \\
\text { PREFERENCE FOR QUALITY AND QUANTITY OF } \\
\text { OFFSPRING }\end{array}$ \\
\hline 11.06 & Turkington, D. & $\begin{array}{l}\text { ON THE DIFFERENTIATION OF THE LOG } \\
\text { LIKELIHOOD FUNCTION USING MATRIX } \\
\text { CALCULUS }\end{array}$ \\
\hline 11.07 & Groenewold, N. and Paterson, J.E.H. & $\begin{array}{l}\text { STOCK PRICES AND EXCHANGE RATES IN } \\
\text { AUSTRALIA: ARE COMMODITY PRICES THE } \\
\text { MISSING LINK? }\end{array}$ \\
\hline 11.08 & Chen, A. and Groenewold, N. & $\begin{array}{l}\text { REDUCING REGIONAL DISPARITIES IN CHINA: IS } \\
\text { INVESTMENT ALLOCATION POLICY EFFECTIVE? }\end{array}$ \\
\hline 11.09 & Williams, A., Birch, E. and Hancock, P. & $\begin{array}{l}\text { THE IMPACT OF ON-LINE LECTURE RECORDINGS } \\
\text { ON STUDENT PERFORMANCE }\end{array}$ \\
\hline 11.10 & Pawley, J. and Weber, E.J. & $\begin{array}{l}\text { INVESTMENT AND TECHNICAL PROGRESS IN THE } \\
\text { G7 COUNTRIES AND AUSTRALIA }\end{array}$ \\
\hline 11.11 & Tyers, $\mathrm{R}$. & $\begin{array}{l}\text { AN ELEMENTAL MACROECONOMIC MODEL FOR } \\
\text { APPLIED ANALYSIS AT UNDERGRADUATE LEVEL }\end{array}$ \\
\hline 11.12 & Clements, K.W. and Gao, G. & QUALITY, QUANTITY, SPENDING AND PRICES \\
\hline 11.13 & Tyers, R. and Zhang, Y. & $\begin{array}{l}\text { JAPAN'S ECONOMIC RECOVERY: INSIGHTS FROM } \\
\text { MULTI-REGION DYNAMICS }\end{array}$ \\
\hline 11.14 & McLure, M. & A. C. PIGOU'S REJECTION OF PARETO'S LAW \\
\hline 11.15 & Kristoffersen, I. & $\begin{array}{l}\text { THE SUBJECTIVE WELLBEING SCALE: HOW } \\
\text { REASONABLE IS THE CARDINALITY ASSUMPTION? }\end{array}$ \\
\hline 11.16 & Clements, K.W., Izan, H.Y. and Lan, Y. & VOLATILITY AND STOCK PRICE INDEXES \\
\hline 11.17 & Parkinson, $\mathrm{M}$. & $\begin{array}{l}\text { SHANN MEMORIAL LECTURE 2011: SUSTAINABLE } \\
\text { WELLBEING - AN ECONOMIC FUTURE FOR } \\
\text { AUSTRALIA }\end{array}$ \\
\hline 11.18 & Chen, A. and Groenewold, N. & $\begin{array}{l}\text { THE NATIONAL AND REGIONAL EFFECTS OF } \\
\text { FISCAL DECENTRALISATION IN CHINA }\end{array}$ \\
\hline 11.19 & Tyers, R. and Corbett, J. & $\begin{array}{l}\text { JAPAN'S ECONOMIC SLOWDOWN AND ITS GLOBAL } \\
\text { IMPLICATIONS: A REVIEW OF THE ECONOMIC } \\
\text { MODELLING }\end{array}$ \\
\hline 11.20 & Wu, Y. & $\begin{array}{l}\text { GAS MARKET INTEGRATION: GLOBAL TRENDS } \\
\text { AND IMPLICATIONS FOR THE EAS REGION }\end{array}$ \\
\hline 11.21 & Fu, D., Wu, Y. and Tang, Y. & $\begin{array}{l}\text { DOES INNOVATION MATTER FOR CHINESE HIGH- } \\
\text { TECH EXPORTS? A FIRM-LEVEL ANALYSIS }\end{array}$ \\
\hline 11.22 & Fu, D. and Wu, Y. & EXPORT WAGE PREMIUM IN CHINA'S \\
\hline
\end{tabular}




\begin{tabular}{|l|l|l|}
\hline & & $\begin{array}{l}\text { MANUFACTURING SECTOR: A FIRM LEVEL } \\
\text { ANALYSIS }\end{array}$ \\
\hline 11.23 & Li, B. and Zhang, J. & $\begin{array}{l}\text { SUBSIDIES IN AN ECONOMY WITH ENDOGENOUS } \\
\text { CYCLES OVER NEOCLASSICAL INVESTMENT AND } \\
\text { NEO-SCHUMPETERIAN INNOVATION REGIMES }\end{array}$ \\
\hline 11.24 & Krey, B., Widmer, P.K. and Zweifel, P. & $\begin{array}{l}\text { EFFICIENT PROVISION OF ELECTRICITY FOR THE } \\
\text { UNITED STATES AND SWITZERLAND }\end{array}$ \\
\hline 11.25 & Wu, Y. & $\begin{array}{l}\text { ENERGY INTENSITY AND ITS DETERMINANTS IN } \\
\text { CHINA'S REGIONAL ECONOMIES }\end{array}$ \\
\hline & & \\
\hline
\end{tabular}


ECONOMICS DISCUSSION PAPERS

2012

\begin{tabular}{|l|l|l|}
\hline $\begin{array}{l}\text { DP } \\
\text { NUMBER }\end{array}$ & AUTHORS & TITLE \\
\hline 12.01 & Clements, K.W., Gao, G., and Simpson, T. & $\begin{array}{l}\text { DISPARITIES IN INCOMES AND PRICES } \\
\text { INTERNATIONALLY }\end{array}$ \\
\hline 12.02 & Tyers, R. & $\begin{array}{l}\text { THE RISE AND ROBUSTNESS OF ECONOMIC } \\
\text { FREEDOM IN CHINA }\end{array}$ \\
\hline 12.03 & Golley, J. and Tyers, R. & $\begin{array}{l}\text { DEMOGRAPHIC DIVIDENDS, DEPENDENCIES } \\
\text { AND ECONOMIC GROWTH IN CHINA AND INDIA }\end{array}$ \\
\hline 12.04 & Tyers, R. & LOOKING INWARD FOR GROWTH \\
\hline 12.05 & Knight, K. and McLure, M. & THE ELUSIVE ARTHUR PIGOU \\
\hline 12.06 & McLure, M. & $\begin{array}{l}\text { ONE HUNDRED YEARS FROM TODAY: A. C. } \\
\text { PIGOU'S WEALTH AND WELFARE }\end{array}$ \\
\hline 12.07 & Khuu, A. and Weber, E.J. & HOW AUSTRALIAN FARMERS DEAL WITH RISK \\
\hline & & \\
\hline & & \\
\hline & & \\
\hline & & \\
\hline
\end{tabular}

